\title{
The relationship between knowledge management and leadership: mapping the field and providing future research avenues
}

\author{
Massimiliano Matteo Pellegrini - University of Rome Tor Vergata, IT \\ Francesco Ciampi - University of Florence, IT \\ Giacomo Marzi - University of Lincoln, UK (ORCID: 0000-0002-8769-2462) \\ Beatrice Orlando - University of Ferrara, IT \\ Published on Journal of Knowledge Management
}

FULL TEXT (DOI): $\underline{\text { https://doi.org/10.1108/JKM-01-2020-0034 }}$

\begin{abstract}
Purpose: Effectively handling knowledge is crucial for any organisation in order to survive and prosper in the turbulent environments of the modern era. Leadership is a central element for knowledge creation, acquisition, utilisation and integration processes. Based on these considerations, this study offers an overview of the evolution of the literature regarding the knowledge managementleadership relationship published over the last twenty years.
\end{abstract}

Design/methodology/approach: A bibliometric analysis coupled with a systematic literature review were performed over a dataset of 488 peer-reviewed articles published from 1990 to 2018.

Findings: We discovered the existence of four well-polarised clusters with the following thematic focuses: human and relational aspects, systematic and performance aspects, contextual and contingent aspects, and cultural and learning aspects. We then investigated each thematic cluster by reviewing the most relevant contributions within them.

Research limitations/implications: Based on the bibliometric analysis and the systematic literature review we developed an interpretative framework aimed at uncovering several promising and little explored research areas, thus suggesting an agenda for future knowledge management-leadership research. Some steps of the paper selection process may have been biased by the interpretation of the researcher. We addressed this concern by performing a multiple human subject reading process whose reliability was confirmed by a Krippendorf's Alpha coefficient value $>0.80$.

Originality/value: To our best knowledge, this is the first study to map, systematise and discuss the literature concerned to the topic of the knowledge management-leadership relationship.

Keywords: Knowledge management, Leadership, Bibliometric analysis, Systematisation of literature, Research agenda. 


\section{Introduction}

Modern organisations face increasing technology development, competitive pressure, and demand shifts. The main thesis of knowledge management theory (Nonaka, 1994; Nonaka et al., 2000) is that these organisations can conquer leadership competitive position only if they are able to distinctively manage their patrimony of knowledge (Lin and McDonough III, 2011). Knowledge management (KM) consists of the organisational routines and practices related to 'handling' knowledge from its creation or external acquisition, to its internal utilisation and integration across the organisational system (Carmeli et al., 2013; Natalicchio et al., 2017).

This implies that the topic of KM is of interest to several disciplines (Ponzi, 2002). For example, information and management information sciences have manly focused on knowledge as an object (Gu, 2004) and inquired KM for its instrumental function (Gaviria-Marin et al., 2019). Management and organisational disciplines, on the other hand, have mostly considered knowledge as a process (Gu, 2004) and focused on how it is produced and handled within and between organisations (Rashman et al., 2009). The development of this second perspective (KM-as-process view) represented the basis for the foundation of the theory of KM (Nonaka, 1994) and led to include KM among top management strategic decisions, with a huge influence on firms' success (Gaviria-Marin et al., 2019; Martins et al., 2019).

Furthermore, in the last decade the process perspective shifted its focus from the engineering and structural aspects to the social dimensions of KM systems (Gaviria-Marin et al., 2019). The success of $\mathrm{KM}$ and its practices is often ascribed to social mechanisms and to an effective adoption and internalisation of such mechanisms by employees and groups (Inkinen, 2016). In addition, an effective KM can occur only if people involved in the process are properly led, engaged, and motivated during the whole process (Bavik et al., 2018; Natalicchio et al., 2017). As a consequence, leadership represents one of the most prominent enablers of KM implementation and success (Ho, 2009; Vera and Crossan, 2004).

Despite the wide agreement concerning the importance of leadership for an effective KM, several scholars (e.g. Rashman et al., 2009; von Krogh et al., 2012) have stressed the need to deepen the KMleadership relationship and the mechanisms through which this relationship is developed. A first group of motivations for this need is connected to the fact that the KM-leadership relation tends to vary intensely according to the leadership 'styles' exerted. For example, the greater effectiveness for KM of a participative and collaborative type of leadership (e.g. Pérez-López et al., 2004) has been questioned with respect to certain cultural contexts, as in the case of collectivistic cultures (e.g. Lee et al., 2018; Ma et al., 2008; Masa'deh et al., 2016). In addition, among collaborative leadership styles there are differences too. Lee et al. (2018) in their meta-analysis on empowering leadership, found no confirmation for its positive effect on knowledge sharing, something that has instead been confirmed for transformational leadership (Dong et al., 2017).

A second group of reasons for deeply analysing and discussing the existing literature on the KMleadership is referred to the current lack of systematisation. Due to the increased pervasiveness of $\mathrm{KM}$ in the firm functioning and its results (Heisig et al., 2016), the KM field has recently reached a stable attention in the academic debate as also evidenced by several bibliometric studies (e.g. GaviriaMarin et al., 2019; Gu, 2004; Ponzi, 2002). In several KM systematic literature reviews, leadership emerges as a relevant factor for an effective KM in general (e.g. Inkinen, 2016; Smith et al., 2008) and within specific KM contexts, such as communities of practices (Bolisani and Scarso, 2014), and public services (Rashman et al., 2009). However, if a significant level of deepening has been reached with regard to the study of the relationship between KM and firm's sustainability strategies (Martins et al., 2019), intellectual capital management (Serenko et al., 2010), and sustainable open innovation system (Natalicchio et al., 2017), the same cannot be said for the intersection between KM and leadership. As a consequence, a specific focus on the KM-leadership relationship is necessary to systematise what exists on the topic and consequentially propose valuable insights on the existing gaps in order to produce valuable bases for future research (Appio et al., 2014; Caputo et al., 2018). 
A third group of motivations is connected with the KM challenges caused by the digital revolution such as the urge to improve the detection of meaningful pieces of information among the vast availability of big data, the necessity to handle an increased level of knowledge inflows, and the need to simplify and personalise KM representation and codification to help users in the data interpretation (Fakhar-Manesh et al., 2019). All these challenges give rise to the need of renewed interests towards analysing through which mechanism leaders of organizations can facilitate and develop the organisational routines that are necessary for effectively managing knowledge in the digital era (Santoro et al., 2018).

The paper's contribution is at least twofold. First, to our best knowledge, this is the first study to systematise existing literature on the KM-leadership relationship. Specifically, our bibliometric coupling analysis highlights four well-polarised clusters with the following thematic focuses: human and relational aspects, systematic and performance aspects, contextual and contingent aspects, and cultural and learning aspects. We investigated each thematic cluster by reviewing the most relevant contributions within them.

Second, we propose an interpretative framework aimed at uncovering several promising and little explored research areas, thus suggesting an agenda for future KM-leadership research, which also take into account the emerging challenges caused by the latest technological evolutions.

The paper is organised as follows. Section two describes the method and protocol adopted for implementing our analysis. The third section presents the bibliometric analysis results while the fourth is dedicated to the cluster analysis and its systematic literature review. The fifth section proposes an interpretative framework aimed at suggesting an agenda for future research. The last section concludes the paper and describes its limitations.

\section{Methods}

The generalised fast-increasing number of scientific publications poses difficulties in keeping a clear track of the evolution and development of the different fields of study. In response to this, bibliometric methods represent powerful instruments for analysing huge amounts of data regarding the research streams of a specific field of study by mapping all pertinent contributions and elaborating spatial distributions able to highlight the relations between them (Appio et al., 2014; Zupic and Cater, 2015). For these reasons and in order to effectively address the challenges related to the KM-leadership literature described in the introduction, we deemed proper to perform a bibliometric analysis based on the visualisation of similarities (VOS) (Van Eck and Waltman, 2010), along with a systematic literature review (Tranfield et al., 2003). Using this approach allowed us to combine the comprehensive quantitative inquiry of a bibliometric analysis with the fine-grained and qualitative investigation made possible by a systematic literature review, thus reducing the shortcomings of both approaches (Appio et al., 2014). This mix methodology has already shown to be successful in similar literature-based studies where KM was studied in relation to other constructs such as the fourth digital revolution (Fakhar-Manesh et al., 2019) and the firm's sustainability (Martins et al., 2019).

The systematic literature review proposed in this study bases its scientific solidity on three main reasons. First, the selection of the analysed papers was performed according to a replicable protocol (Cillo et al., 2019; Tranfield et al., 2003), as described in section 2.1. Second, the theoretical framework used to analyse the selected papers was not subjectively determined by the authors but organised according to the VOS clustering algorithms results (Appio et al., 2014; Van Eck and Waltman, 2010; Zupic and Carter, 2015), as described in section 2.2. Third, the discussion and interpretation of the topics treated within each cluster followed the guidelines of a systematic literature review, largely used in the KM field (e.g. Martins et al., 2019; Natalicchio et al., 2017), which allowed to perform an in-depth, qualitative investigation of the thematic structure and content of each cluster. 


\subsection{Data gathering}

Similar to what Martin et al. (2019) did in their literature review concerning KM and sustainability, our analysis started with an overarching question: What are the existing relationships between KM and leadership? Thus, the iterative search process of defining the query for our bibliometric analysis started by focusing on two main terms, "knowledge management" and "leadership". However, the concept of KM can either refer to an overall bundle of practices or to a single and specific process concerning KM practices. Thus, in order to grasp the full extent of the field of study object of our analysis, we realised that it was necessary to use additional terms for the query. These additional terms allowed us to embrace an up-to-date and comprehensive definition of KM (Inkinen, 2016; Natalicchio et al., 2017). In particular, we included all the terms related to the KM processes, such as knowledge acquisition (KAc), knowledge creation (KC), knowledge sharing or transfer (KS), knowledge storage (KSt), and knowledge application (KApp).

The final result of our iterative query definition process was the following: "TITLE-ABS-KEY ("knowledge management" OR "managing knowledge" OR "knowledge acquisition" OR "acquiring knowledge" OR "knowledge creation" OR "creating knowledge" OR "knowledge transfer" OR "transferring knowledge" OR "knowledge sharing" OR "sharing Knowledge" OR "storing knowledge" OR "knowledge Application" OR "Knowledge applying") AND TITLEABS-KEY (leadership)", where "TITLE-ABS-KEY" is an operator that performs searches in titles, abstracts, and keywords.

This query was performed on the Scopus database, which represents the most comprehensive source of data to retrieve high-quality and peer-review publications for an emergent field of studies (Falagas et al., 2018). The search was limited to journal articles in the English language published up until December 31, 2018. The search produced an initial dataset of 658 papers. In order to ensure the inclusion of all relevant data, a cross-validation analysis was made by applying the same research string on the Web of Science and EBSCO Business Premier databases. This analysis did not identify any missing data, thus confirming the validity of using both our query string and the Scopus database. Next, following the best methodological practices proposed by the literature (e.g. Tranfield et al., 2003), three out of the four authors carried out a screening analysis of the 658 papers independently. Specifically, following consolidated standards in the literature-based studies on KM (e.g. Inkinen, 2016; Martins et al., 2019; Natalicchio et al., 2017; Rashman et al., 2009), the following paper selection protocol (figure 1) was adopted (Cillo et al., 2019):

1) titles, abstracts, and keywords screening. Through this phase 79 papers were removed as not pertinent either to leadership or KM. In particular, some papers (35), although containing the term "leadership", used it only as a synonymous of top management or to indicate a type strategy (e.g. market or cost leadership) (e.g. Raudeliūnienè et al., 2018). Other papers (44), though making a general reference to managing knowledge, did not really focus on KM or on any of its processes (e.g. Bhatnagar, 2017);

2) full texts screening. In this phase the dataset was further polished by reading the full texts of all the remaining papers in order to ensure a strict adherence to the theme object of the study (Caputo et al., 2018). This second screening led to remove another 83 papers. 48 papers were removed as they dealt with leadership only generically in their future research propositions or managerial implications, indicating for example that more attention should be paid to the leadership aspect, without any further suggestion or investigation (e.g. Birnbaum et al., 2018). 35 papers were removed because, though focusing on both leadership and knowledge management, they did not analyse any connection between the two constructs (e.g. Sievert and Scholz, 2017);

3) search for duplication. Finally, 8 papers were eliminated as they represented pure duplications, or insights extracted from other papers already included in the dataset.

For all these screening phases, we used Krippendorf's Alpha coefficient as a statistical measure of the agreement achieved between the authors. The resulted $\mathrm{K}$ was always greater than 0.8 , indicating a reliable convergence and strong inter-reliability of the performed selection process. 
After performing this screening process, our dataset was reduced to 488 papers (see Appendix 1 for a full list of these manuscripts).

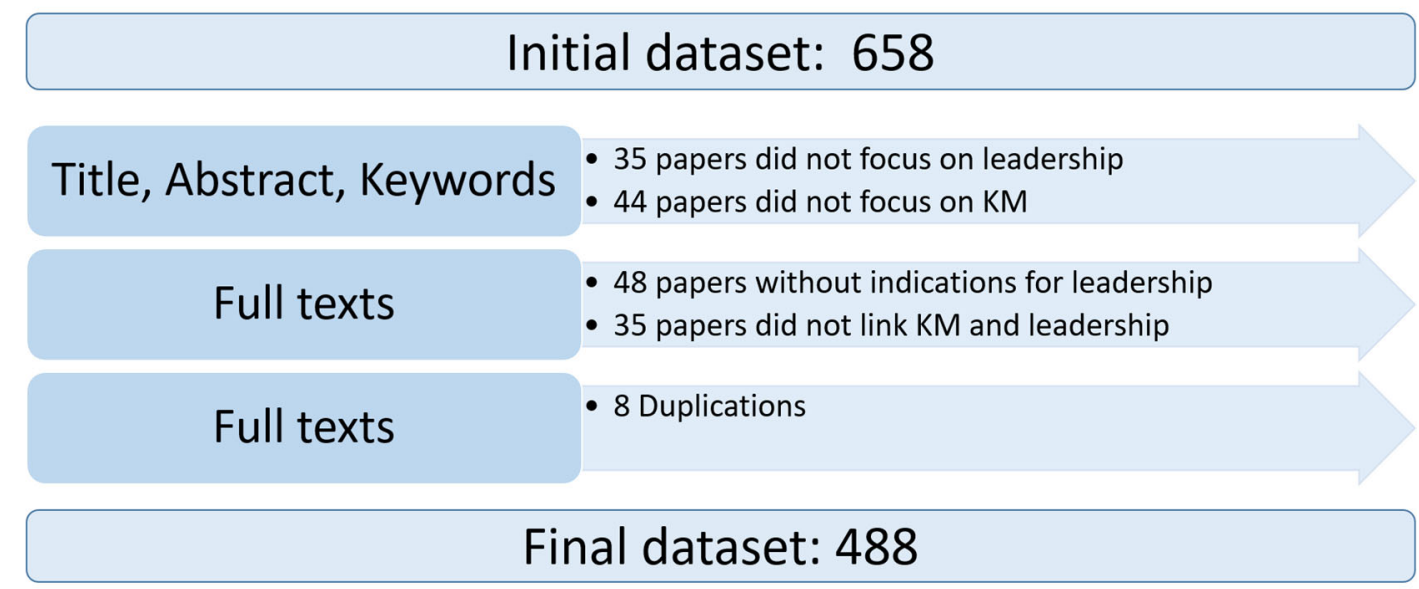

Figure 1. Protocol for selecting papers

\subsection{Analysis}

Our final dataset of 488 papers was object of the bibliometric analysis. First, we calculated a series of bibliometric activity indicators (see the next section). We used these indicators to analyse our dataset in terms of distribution of papers across years and the most relevant journals (Todeschini and Baccini, 2016).

Subsequently, we moved to the core of our bibliometric investigation by using VOSviewer 1.6.10. The software was used for the similarity analysis and for aggregating papers through bibliographic coupling (Van Eck and Waltman, 2010, 2014). Bibliographic coupling occurs when two papers cite the same third paper in their references (Zupic and Cater, 2015). We decided to use the bibliographic coupling aggregation method due to its ability to detect the developments of a given intellectual structure within a field by highlighting the main theoretical approaches and relationships between papers (Appio et al., 2014; Zupic and Cater, 2015).

VOS algorithms construct a similarity matrix by normalising a co-occurrences matrix of the references (Van Eck and Waltman, 2010). The VOS technique builds a two-dimensional map in which the items 1 to $n$ are positioned to represent, in the axes $x$ and $y$, their similarity in term of cited references. In particular, VOS performs a set of routines known as: i) translation, in order to spatially centre each point in reference to the origin; ii) rotation, in order to maximize the variance of the solutions; and iii) reflection, in order to correctly locate on the vertical and horizontal axes the coordinates (Appio et al., 2014). The result is a matrix in which items' distance can be interpreted as an indication of the relatedness of the terms. The smaller the distance between the terms, the stronger the terms are related to each other (Van Eck and Waltman, 2010, 2014). Based on this matrix, we implemented the VOS clusterization analysis, which reflects the diversity of the knowledge bases used in the set of papers. Papers belonging to the same cluster are strongly linked each other, thus representing a univocal stream of research or a specific approach to a topic (Appio et al., 2014; Van Eck and Waltman, 2010). In line with the best methodological practices suggested by the literature (Van Eck and Waltman, 2010) the cluster analysis was performed with a minimum cluster size of 10 and a resolution value of 1.00. As suggested for large datasets (Van Eck and Waltman, 2010, 2014), as it is the case of our study, we used a threshold for the minimum link strength of 50. Finally, in order to double-check the goodness of the analysis, each paper inside each cluster was manually examined by two of the four authors in order to confirm the homogeneity and the soundness of the clusterization process (Appio et al., 2014).

The result of the VOS clusterization analysis was a dataset of 450 interconnected papers ( $92 \%$ of the 488 papers dataset) giving the form to a four-cluster structure (see section 4 ). 
Subsequently, always in line with the best methodological practices (Tranfield et al., 2003), three out of the four authors independently scored these 450 papers based on their total and normalised citations as well as their relevance for the main topics of each cluster. This step aimed to select a viable amount of papers to be the object of the systematic review presented in section 4 . For this final selection phase, we again used Krippendorf's Alpha coefficient as a statistical measure of the agreement achieved. The resulted $\mathrm{K}$ was also in this case greater than 0.8 , indicating a solid convergence and inter-reliability of the performed selection process. Through this final step, a restricted dataset composed of 40 papers was selected to be systematically reviewed.

\section{Results of the bibliometric activity indicators}

Our bibliometric analysis confirms a constant growth of attention to the KM-leadership relationship over time. The distribution of papers per year (Figure 2) shows that, from a pre-millennium rate (1998 to 2000) of less than 5 papers per year, the yearly contributions significantly increased in later decades. Although the search was implemented over all the documents published up to December 31, 2018, the first paper detected by our query was published in 1990 and the application of the selection protocol described in section 2.1 reduced the covered period to 1998-2018.

Specifically, the decade 2001 to 2010 has more than 15 papers per year on average, with a breakdown of 10 papers in the first half and about 20 in the second half. The current decade (2011 to 2018) has 35 papers per year on average, with a strong hike in the second half, with over 40 papers per year. Thus, the interest in the leadership aspect of KM is not only theoretically robust (Xue et al., 2011) but also empirically confirmed.

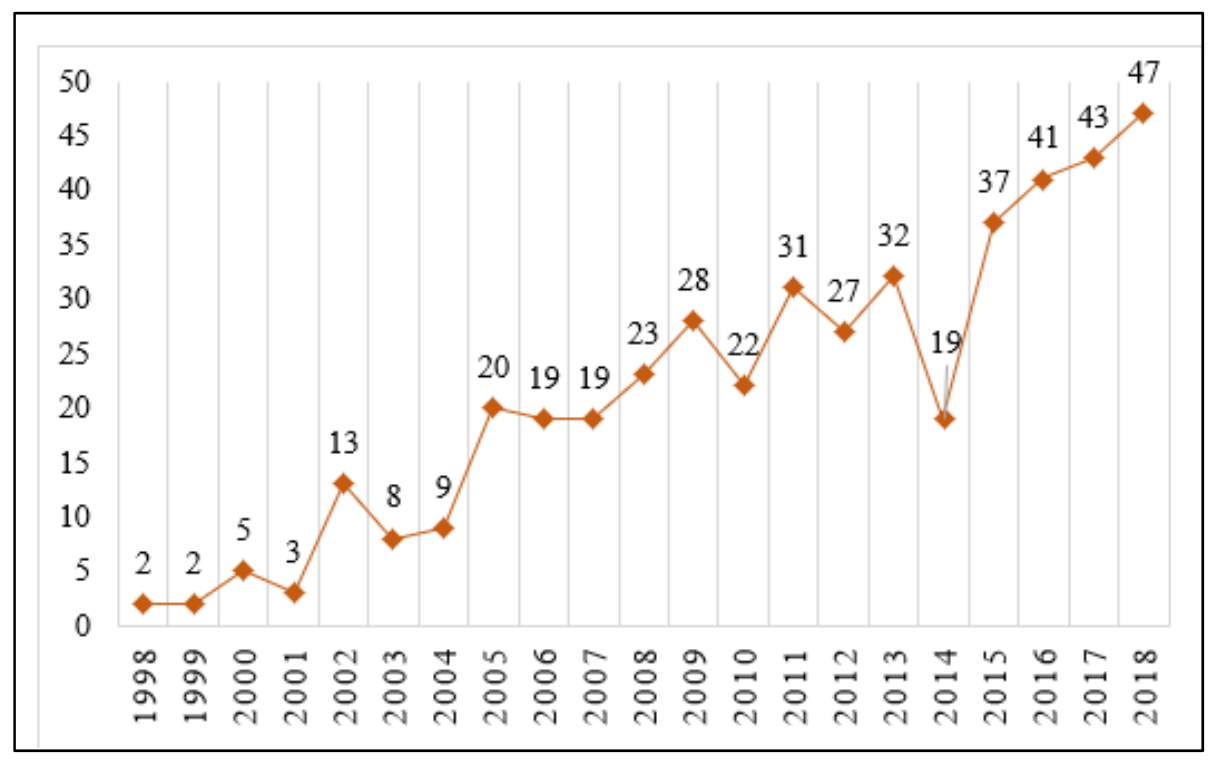

Figure 2-Number of contributions per year

The most influential journal is the Journal of Knowledge Management with more than 50 papers and 2,000 citations, followed, at a great distance, by Knowledge Management Research and Practice (Table 1). This rank contains some examples of leadership journals, e.g. Leadership and Organization Development Journal (12 papers) and Leadership \& Organization Development Journal (9), showing that leadership scholars pay significant attention to the leader role of managing knowledge.

\begin{tabular}{|l|l|l|}
\hline Journal & NP & TC \\
\hline Journal of Knowledge Management & 51 & 2341 \\
\hline Knowledge Management Research and Practice & 12 & 123 \\
\hline Leadership and Organization Development Journal & 12 & 186 \\
\hline Learning Organization & 12 & 218 \\
\hline
\end{tabular}




\begin{tabular}{|l|l|l|}
\hline Journal of Management Development & 11 & 167 \\
\hline Leadership \& Organization Development Journal & 9 & 310 \\
\hline International Journal of Innovation and Learning & 8 & 82 \\
\hline Industrial Management and Data Systems & 6 & 481 \\
\hline International Journal of Human Resource Management & 6 & 177 \\
\hline Management Decision & 6 & 136 \\
\hline Health Care Management Review & 5 & 98 \\
\hline Human Resource Management & 5 & 242 \\
\hline International Journal of Knowledge Management & 5 & 18 \\
\hline International Journal of Managing Projects in Business & 5 & 22 \\
\hline Journal of Workplace Learning & 5 & 36 \\
\hline School Leadership and Management & 5 & 57 \\
\hline $\begin{array}{l}\text { Key: } \\
\text { NP = number of papers; TC = total number of citations }\end{array}$ \\
\hline \multicolumn{2}{|l|}{ Table 1 - Journals with at least five papers published } \\
\hline
\end{tabular}

\section{Results of the VOS Analysis and Literature Review}

The cluster structure resulting from the VOS analysis consists of a quite dense network (Figure 3), indicating that papers are well connected and use fairly similar streams of literature to infer insights about the KM-leadership relationship. Our results individuate a four-cluster structure, with two clusters, i.e. the red and blue ones, that are very well defined and the other two that tend to slightly overlap each other. 


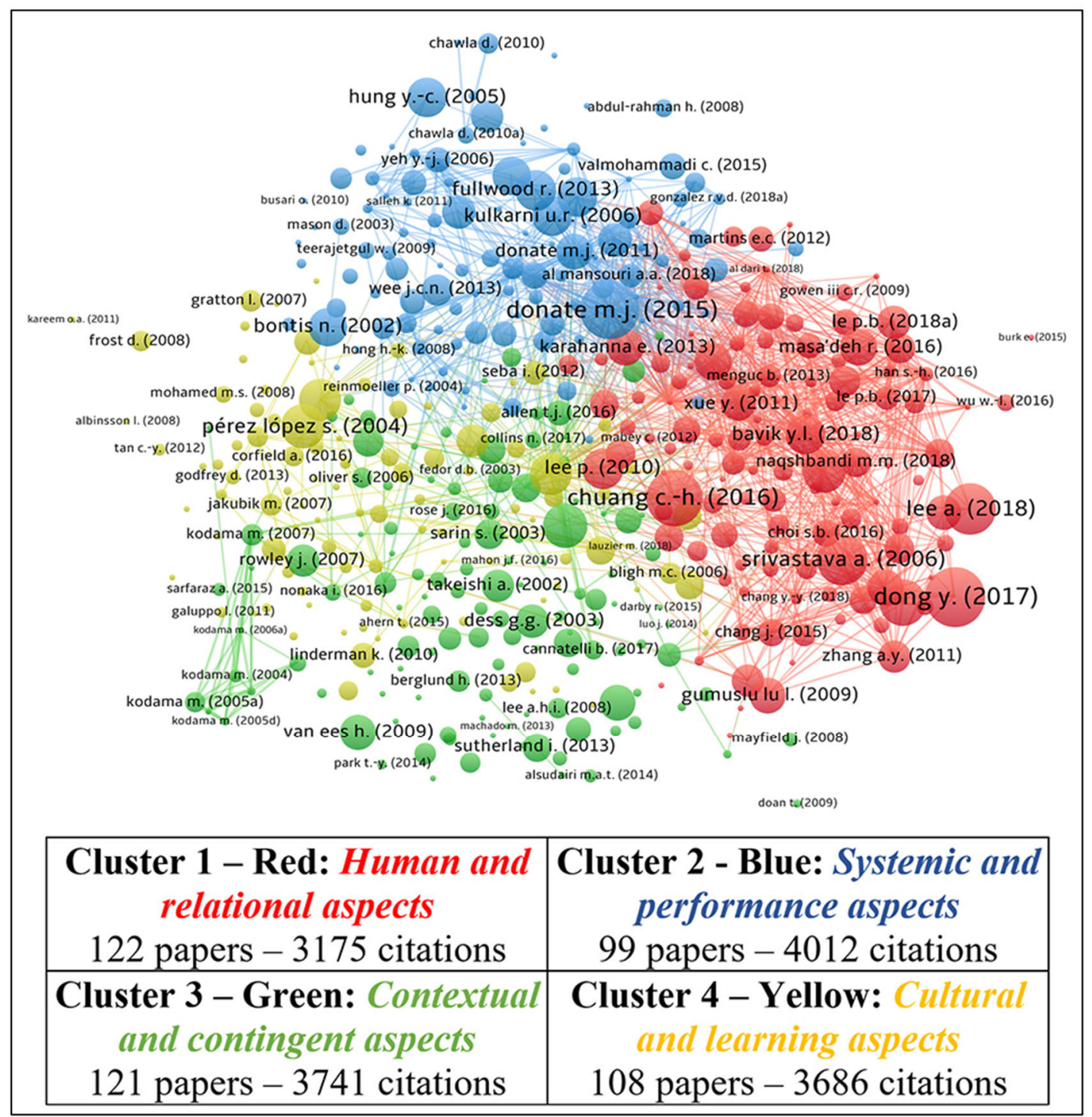

Figure 3-VOS coupling structure

The cluster map represents the intellectual structure of the KM-leadership relationship field (Appio et al., 2014; Caputo et al., 2018). In addition to focusing on different thematic areas, which are fully reviewed in the following sub-sections, the four clusters use different approaches to interpret the role and meaning of knowledge (Mingers, 2008) and, consequentially, different perspectives to approach KM (Gaviria-Marin et al., 2019), as summarized in table 2.

\begin{tabular}{|l|l|l|l|l|}
\hline Cluster & $\begin{array}{l}\text { Red: human and } \\
\text { relational aspects }\end{array}$ & $\begin{array}{l}\text { Blue: systemic and } \\
\text { performance aspects }\end{array}$ & $\begin{array}{l}\text { Green: contextual and } \\
\text { contingent aspects }\end{array}$ & $\begin{array}{l}\text { Yellow: cultural and } \\
\text { learning aspects }\end{array}$ \\
\hline
\end{tabular}




\begin{tabular}{|c|c|c|c|c|}
\hline $\begin{array}{l}\text { Thematic } \\
\text { focus and } \\
\text { exemplary } \\
\text { references }\end{array}$ & $\begin{array}{l}\text { The focus is on the } \\
\text { social process of } \\
\text { leading people (e.g. } \\
\text { Bavik et al., 2018; } \\
\text { Dong et al., 2017). }\end{array}$ & $\begin{array}{l}\text { The focus is on the } \\
\text { systemic and structural } \\
\text { aspects and the } \\
\text { organisational } \\
\text { mechanisms to manage } \\
\text { and exploit knowledge } \\
\text { with the maximum } \\
\text { level of efficiency and } \\
\text { efficacy (e.g. Donate } \\
\text { and Sánchez de Pablo, } \\
\text { 2015; Kulkarni et al., } \\
\text { 2006). }\end{array}$ & $\begin{array}{l}\text { The general focus is on } \\
\text { the procedural aspects of } \\
\text { KM; however, specific } \\
\text { attention is dedicated to } \\
\text { the conditions and } \\
\text { contingencies of the } \\
\text { 'space' in which KM } \\
\text { processes occur (e.g. } \\
\text { Yang, 2007; Pan and } \\
\text { Scarbrough, 1998, } \\
\text { 1999). }\end{array}$ & $\begin{array}{l}\text { The focus is on the } \\
\text { organisational } \\
\text { culture, its impact on } \\
\text { the firm system, the } \\
\text { social mechanisms } \\
\text { and the learning } \\
\text { processes it activates } \\
\text { at the individual level } \\
\text { (e.g. Flores et al., } \\
\text { 2012; von Krogh et } \\
\text { al., 2012). }\end{array}$ \\
\hline $\begin{array}{l}\text { Knowledge } \\
\text { view } \\
\text { (Mingers, } \\
\text { 2008) }\end{array}$ & $\begin{array}{l}\text { Knowledge is seen as } \\
\text { an element of the } \\
\text { transitive domain } \\
\text { (subjective), } \\
\text { intimately tied to the } \\
\text { human processes that } \\
\text { create it and validated } \\
\text { through a fiduciary } \\
\text { process based on trust } \\
\text { between individuals } \\
\text { and/or on factual } \\
\text { personal experience } \\
\text { and evidence. }\end{array}$ & $\begin{array}{l}\text { Knowledge is seen as } \\
\text { an element of the } \\
\text { intransitive domain } \\
\text { (objective) that exists } \\
\text { regardless of } \\
\text { individual } \\
\text { interventions, and that } \\
\text { is therefore objectively } \\
\text { measurable. }\end{array}$ & $\begin{array}{l}\text { Knowledge is seen as } \\
\text { posed at the crossroad } \\
\text { between transitive } \\
\text { (subjective) and } \\
\text { intransitive (objective) } \\
\text { domains. This implies } \\
\text { that knowledge, } \\
\text { although being the result } \\
\text { of a human process, may } \\
\text { be affected by the } \\
\text { concrete social and } \\
\text { cultural contexts in } \\
\text { which its management } \\
\text { occurs. }\end{array}$ & $\begin{array}{l}\text { Knowledge is seen as } \\
\text { an element of both } \\
\text { the transitive } \\
\text { (subjective) and the } \\
\text { intransitive } \\
\text { (objective) domain. }\end{array}$ \\
\hline $\begin{array}{l}\text { Approach to } \\
\text { KM } \\
\text { (Gaviria- } \\
\text { Marin et al., } \\
\text { 2019) }\end{array}$ & $\begin{array}{l}\text { The cluster } \\
\text { approaches KM as a } \\
\text { social process. }\end{array}$ & $\begin{array}{l}\text { The cluster approaches } \\
\text { KM as an instrument } \\
\text { with a strong focus on } \\
\text { systemic and } \\
\text { engineering aspects. }\end{array}$ & $\begin{array}{l}\text { The cluster adopts a } \\
\text { quite marked processual } \\
\text { approach to KM, which } \\
\text { focuses on both } \\
\text { engineering and social } \\
\text { dimensions. }\end{array}$ & $\begin{array}{l}\text { The cluster adopts a } \\
\text { processual approach } \\
\text { to KM though with a } \\
\text { strong focus on social } \\
\text { mechanisms. }\end{array}$ \\
\hline
\end{tabular}

Table 2 - Thematic focus and approaches of the four clusters

\subsection{Cluster 1 Red-Human and relational aspects}

The red cluster concerns the human aspects of the KM-leadership relationship. Most of the papers adopt a specific theoretical perspective on leadership, with the aim of explaining its influence on several organisational outcomes. Transformational leadership (TrFL) and empowering leadership (EmpL) are heavily inquired paradigms by the most impactful papers. The level of analysis is usually centred on the individual and team level, with the most investigated themes being the direct leaderfollower relation (e.g. Masa'deh et al., 2016; Xue et al., 2011), relational aspects in teams (e.g. Carmeli et al., 2013), or combination of both (Dong et al., 2017). A much lower number of contributions analyse the effects of human relations on higher organisational outcomes (e.g. Karahanna and Preston, 2013). The methodological approach adopted is generally quantitative. As it influences the engagement of followers, which is also crucial for the success of KM processes (Birasnav, 2014), TrFL is a recurring inquired style. Mittal and Dhar (2015) show how TrFL effectively foster employees' creativity in culture environments that support KS, by developing employees' confidence in their creative skills. Expanding these results, Dong et al. (2017) inquire separately individual members' and team creativity outcomes. Their study confirms that TrFL promotes both individual creativity skills and KS practices. At the group level transformational leaders foster a team climate that favours KS, enhancing the overall creativity of the group. This climate, in turn, increases the possibilities for individual members to apply their creativity skills. 
EmpL is another leadership style strongly inquired due to its capacity of stimulating intrinsic motivation and autonomy in followers (Srivastava et al., 2006). Team performance is the mainly studied object in relation to EmpL. Indeed, EmpL promotes effective KS practices because team members are stimulated to share ideas by an empowering leader giving them a fair recognition for these behaviours (Srivastava et al., 2006). In turn, KS improves team performance as it assists the creation of shared mental schemata among team members, thus allowing a fast execution with less conflicts. KS also improves the acquisition and sharing of a transactive memory, i.e. the idiosyncratic knowledge map possessed by each individual in a team, which allows people to anticipate other member's behaviours. Xue et al. (2011) delve more deeply into this EmpL-KS relation by adding an important mediation effect: the psychological attitude to sharing knowledge. At a cognitive level, through the above-mentioned processes an empowering leader favours the intentions/attitudes of followers towards KS. Furthermore, at a behavioural level, EmpL may help team members remove barriers impending actual KS behaviours, such as the fear of losing social status.

Other studies analyse ethical leadership (EthL) and its effect on KS behaviours. Starting from the premise that both EthL and KS are intrinsically pro-social behaviours, Bavik et al. (2018) prove that two mechanisms partially mediate the relation between these two constructs. First, transactional means, such as the capacity of a leader to implement a coherent reward/punishment system, extrinsically motivate employees to share ideas. Second, a leader representing an ethical $/ \mathrm{moral}$ example for employees may act in a transformational sense and enact endogenous transformations in followers' behaviours.

However, leadership is not the only factor that affects KM processes. Chuang et al. (2016) find a positive impact of formal HRM systems on KAc and KS processes activated by knowledge-intensive R\&D teams. Their results challenge researchers to further inquire other factors that may affect team KM processes; for example, could an EmpL strongly focused on followers represent a substitute of formal procedures of HRM? Actually, when HRM formal systems and EmpL co-exist they may weaken each other's benefits, thus opening a debate about using formal versus informal practices to boost team performance.

\subsection{Cluster 2 Blue - Systemic and performance aspects}

Compared to the red cluster, the blue cluster adopts a quite opposite perspective for investigating the KM-leadership relationship. In fact, a central importance is dedicated to the systemic and organisational aspects of KM, with a strong focus on its outcomes and impacts.

Most of the papers holistically analyse KM (e.g. Wee and Chua, 2013), its antecedents (e.g. Sigh, 2008), its operational functioning (e.g. Kulkarni et al., 2006), and its consequences (e.g. Bontis and Fitz-enz, 2002; Ho, 2009; Ma et al., 2008). The blue cluster is focused on the assessment of the real contribution of KM to organisational performances at several layers and with regard to different types of performances, such as KM system effectiveness (e.g. Sigh, 2008), innovation performance (e.g. Donate and Sánchez de Pablo, 2015), HRM practices performance (e.g. Yahya and Goh, 2002), or global firm performance (e.g. Valmohammadi and Ahmadi, 2014).

Within this cluster leadership is found as one of the key factors for an effective KM implementation. Inkinen (2016), in his literature review, finds that leadership, or any other 'soft' tool of the organisational culture, besides being a key antecedent of an effective KM, should also be integrated with structural arrangements, such as KM units or reward and training systems, in order to produce strong results. As noted by Sigh (2008) and Yang (2010), leadership styles are also relevant. More coercive styles of leadership, oriented towards regulations, suppress creativity and KM engagement of employees. On the contrary, collaborative leadership styles encourage employees to explore new alternatives autonomously and favours engagement.

The cluster also dedicates attention to the effects of KM practices on innovation performance. For example, Donate and Sánchez de Pablo (2015) study the impact of KM practices (KC, KApp, KSt, $\mathrm{KS}$ ) on product innovation rate. They find that knowledge-oriented leadership, a style that encompasses managerial and reward systems (transactional approach), as well as inspirational and 
empowering behaviours for employees (transformational aspects), is the most significant antecedent of all KM practices. However, only KApp and $\mathrm{KC}$ significantly improve product innovation rate, while KSt and KS are mostly related to process innovation (p. 367).

Another performance dimension analysed in this cluster is that related to human resource practices. For example, Bontis and Fitz-enz (2002) find that leadership affects the retention rate of key employees both directly and indirectly, through its positive impact on KS practices, thus increasing the returns on human capital. Yahya and Goh (2002) analyse the impact of HRM practices on KM and find that KM success is achievable only if leadership skills are present throughout the entire organisation, especially at the middle management level. The consequence is that a decentralised decision-making approach should be adopted as it provides both adequate training of the soft skills of the employees and adequate opportunities to exercise them.

Finally, some studies analyse the contribution of KM to the global (economic, operative, and market) organisational performance. For example, Valmohammadi and Ahmadi (2014), using a balance scorecard approach, assess eight enablers of KM. KM strategy and organisational culture are the most influential enablers of KM, while the leadership factor, though significant, is not as relevant.

\subsection{Cluster 3 Green - Contextual and contingent aspects}

The green cluster analyses the KM-leadership relationship using a contextualisation prospective. It specifically emphasises the milieu ( $\mathrm{Ba}$ Japanese word for 'place') where knowledge is created, shared, and used (Nonaka et al., 2000).

A large part of the cluster focuses on KM organisational processes occurring in different operational contexts, such as in the hotel industry (Yang, 2007) and university relations (Dooley and Kirk, 2007). While industry contexts are preponderant, even because most influential papers are published on sectoral journals (e.g. Tourism management), KM is also analysed across multiple Bas or different layers, e.g. a team context, or a formal organisational structure context (Pan and Scarbrough,1998, 1999), or a strategic level (Dess et al., 2003; Van Ees et al., 2009). The papers of the cluster sometimes do not analyse leadership directly and/or autonomously but include it into the intentions or behaviours of the main actors governing the KM processes.

One of the most comprehensive studies on KM contextualisation is that of Pan and Scarbrough (1998, 1999), which is performed in a large chain of chemical laboratories. Perfectly in line with the epistemological interpretation of knowledge adopted in the cluster, they study KM as a sociotechnical system, paying simultaneous attention to the relationships between the individuals working in the system and the system itself. Similar to what will be later proposed by von Krogh et al. (2012), they conceive KM at three layers: the infrastructure or objective level, dealing with the types of content-knowledge and how it is stored (KSt), the 'infostructure' or the inter-subject level, related to KS practices and rules for people to interact, and the 'infoculture' or the subjective level, dealing with the strengths and embeddedness of informal relations related to $\mathrm{KC}$. To effectively develop such a multi-layered system, leadership should focus on overcoming resistance to change, by both working at the individual and interactional levels and removing structural barriers, in order to facilitate communication through the several layers.

Some other papers specifically consider conflicts that may occur in a $B a$, thus focusing on the intersubject $B a$ level ('infostructure' in Pan and Scarbrough, 1998). For example, Van Ees et al. (2009) argue that besides resolving conflicts, board of directors' effective leadership behaviours should also be directed to integrate and share knowledge (KS) and information deriving from alternatives goals brought forth by coalitions of organisational actors.

Innovation management is one of the most studied operational contexts in this cluster (e.g. CaridiZahavi et al., 2016). Smith et al. 's (2008) systematic literature review summarises all factors influencing the ability of a firm to innovate. They show that leadership (considered as the capability to empower and motivate employees) is a fundamental predictor of the ability of the employees to 'feed' innovative processes with their ideas, while KM (principally seen as internal KS) plays a mediation role within the relationship between leadership and firm innovation capability. This is 
because a leader that facilitates knowledge flows from outside and encourages employees to use it creatively will shape an effective KS culture and this in turn will improve ambidexterity (Lin and McDonough III, 2011).

Innovation management is not the only operational context analysed in the cluster. For example, Yang (2007), by analysing the hotel industry, finds that KS practices are central within the whole KM system because they prevent knowledge from remaining orphan in functional silos, with little benefit for the whole organisation. The study shows how leadership, together with organisational culture, may enhance or hamper KS practices; 'facilitating' and 'mentoring' roles have the most positive impacts on KS, while playing an 'innovator' role has a minor effect. Instead, keeping a tight control of the employees ('monitoring') significantly reduces their willingness to share knowledge.

\subsection{Cluster 4 Yellow - Cultural and learning aspects}

The yellow cluster focuses on the cultural and learning aspects of the KM-leadership relationship. The theoretical focus of a large part of the papers is on organisational culture and environments and how these elements affect KM or vice versa. KM and its sub-processes are sometimes directly considered (e.g. Brewster et al., 2005); more often, KM is analysed within the organisational learning domain. Although no complete common agreement exists, organisation learning is seen quite consistently (e.g. Flores et al., 2012; Pérez-López et al., 2004) as knowledge and information acquisition (KAc), knowledge and information distribution (KS), knowledge and information interpretation and information integration (to some extents, KS and KApp), and organisational memory development (mostly KSt).

Since culture and the learning processes associated to it are strongly shaped by leadership behaviours (Vera and Crossan, 2004), the role of the leadership dimension is quite pervasive in this cluster. As in the blue cluster, leadership is generally assumed as one of the cultural antecedents of organisational learning or KM (Flores et al., 2012). However, leadership is also acknowledged as a shaping factor of the culture (as in Zboralski, 2009), implicitly considered as a requisite for a certain type of culture (e.g. a participative leadership as in Pérez-López et al., 2004), or a facilitator of individual learning (Marcinkus-Murphy, 2012).

The four knowledge conversion processes (through which knowledge can be created) proposed by the SECI model (Nonaka et al., 2000) take place in a specific cultural context $(\mathrm{Ba})$, which sets the boundaries to the interactions among individuals and, consequently, to the KC potential itself. Furthermore, the SECI processes need appropriate knowledge assets (i.e., inputs) to operate as well as generate other final knowledge assets (outputs), which, in turn, can be cyclically and continuously reused for other $\mathrm{KC}$ processes. Besides offering a vision and proposing promising knowledge trajectories to be pursued, leadership should effectively govern all the three above mentioned elements, i.e. the $S E C I$ processes, the $B a$, and the knowledge assets. In fact, for an effective KM, leaders should constantly monitor, promote, and stimulate the $S E C I$ processes, continuously control and refine the knowledge assets, and focus on constantly energising the $B a$, thus creating a cultural context that stimulates and facilitates interactions.

Similar to what theorised by Pan and Scarbrough (1998, 1999), von Krogh et al. (2012) expanded the Nonaka et al.'s (2000) model comparing the benefits of distributed and centralised leadership styles at three organisational layers.

While these two milestones holistically study the KM phenomenon, other papers more specifically analyse particular cultural aspects that may impact on KM. For example, Seba et al. (2012), studying the police force of Dubai, propose a reverse logic, analysing the cultural aspects that may impede a full embeddedness and adoption of KM practices, in particular KS. Leadership needs to promote a participative climate, where contributions are valued in order to prevent employees from not seeing the practical relevance of KS.

Other impactful papers, still study culture but assuming an organisational learning perspective. Flores et al. (2012) highlight the importance of the promotion of a collaborative decision-making process and of transformational leadership behaviours. They find that the latter is the most impactful cultural 
element for organisational learning as it influences KAc, KS, information interpretation and integration ( $\mathrm{KC}$ and $\mathrm{KApp}$ ), as well as organisational memory development (KSt). Collaborative decision making instead impacts only on information integration and interpretation (KS and KApp). Beside impacting at the overall organisational level, culture may also play a role at lower layers (von Krogh et al., 2012), namely at the group level. Bligh et al. (2006) indicate that KC within teams effectively occurs when a shared leadership emerges and is the result of a within-group cultural context based on three dimensions: trust, team potency, i.e. the perception of efficiency of the group, and the commitment of its members. This team culture is reachable only if members assume a selfleadership posture, thus taking managerial responsibilities in performing a task and developing intrinsic motivations towards this extra-role commitment.

Besides being influenced by it, KM can also be seen as an element affecting culture (Corfield and Paton, 2016). This perspective specifically emerges in relation to organisational change issues where the persistence of leadership's efforts is an often-recalled success factor (e.g. Jacobs et al., 2013).

\section{Setting-up a Research Agenda}

The bibliometric analysis and literature review presented in the previous sections fill the research gaps suggested by Inken (2016) and von Krogh et al. (2012). According to them, a comprehensive systematisation of the KM literature could not be considered complete without a serious consideration of the role of leadership. Furthermore, this systematisation paves the way to several future promising research avenues (RAs) (Caputo et al., 2018; Tranfield et al., 2003).

\begin{tabular}{|c|c|c|c|c|}
\hline $\begin{array}{l}\text { KM-LEADERSHIP } \\
\text { EMERSTERS } \\
\text { KM THEMES }\end{array}$ & $\begin{array}{l}\text { Red Cluster - } \\
\text { Human approach }\end{array}$ & $\begin{array}{l}\text { Blue Cluster - } \\
\text { Systemic approach }\end{array}$ & $\begin{array}{l}\text { Green cluster - } \\
\text { Contextual approach }\end{array}$ & $\begin{array}{l}\text { Yellow cluster- } \\
\text { Cultural approach }\end{array}$ \\
\hline Business strategy & - & $(\mathrm{x})$ & $(\mathrm{x})$ & $\mathrm{X}$ \\
\hline $\begin{array}{l}\text { Intellectual capital } \\
\text { Human capital } \\
\text { Structural capital } \\
\text { Relational capital }\end{array}$ & $\begin{array}{l}X \\
\text { (x) } \\
-\end{array}$ & $\begin{array}{l}(\mathrm{x}) \\
\mathrm{X} \\
-\end{array}$ & $\begin{array}{l}X \\
(x) \\
X\end{array}$ & $\begin{array}{l}X \\
X \\
X\end{array}$ \\
\hline Decision making & $\mathrm{X}$ & - & $\mathrm{X}$ & $\mathrm{X}$ \\
\hline Knowledge Sharing & $\mathrm{X}$ & $\mathrm{X}$ & $\mathrm{X}$ & $\bar{X}$ \\
\hline Organisational learning & $(\mathrm{x})$ & $(\mathrm{x})$ & $(\mathrm{x})$ & $\mathrm{X}$ \\
\hline Innovation & $(\mathrm{x})$ & $\mathrm{X}$ & $\mathrm{X}$ & - \\
\hline Productivity & $(\mathrm{x})$ & $\mathrm{X}$ & - & - \\
\hline Competitive advantage & (x) & - & $\mathrm{X}$ & (x) \\
\hline
\end{tabular}

Table 3-KM-Leadership future research framework

By crossing our four thematic clusters with the emerging KM themes foreseen by a reworked version of the schematisation elaborated by Heisig et al. (2016, p. 1174) (table 3), it is possible to highlight that KM inputs (intellectual capital) and activities (decision making, KS, and organisational learning) are well-addressed by the extant literature, with a prominence given to human capital and KS practices, while KM outcomes (innovation, productivity, and competitive advantage) are less studied. Based on this interpretative framework, for each cluster we propose: a) a set of 'exploitative RAs', i.e. directions that despite having already been investigated, may still present an interesting potential of further development and capitalisation; b) a set of 'explorative RAs', i.e. directions that have been investigated either not or to a very limited extent (table 4). 


\begin{tabular}{|c|c|}
\hline $\begin{array}{l}\text { KM- } \\
\text { LEADERSHIP } \\
\text { CLUSTERS } \\
\end{array}$ & FUTURE RESEARCH AVENUES (RAs) \\
\hline $\begin{array}{l}\text { RED CLUSTER } \\
\text { (HUMAN } \\
\text { APPROACH) }\end{array}$ & $\begin{array}{l}\text { Exploitative RAs } \\
\text { Decision making and human capital } \\
\text { How does leadership, in general and according to diverse leadership styles, differently } \\
\text { influence KM activity outcomes at individual and group levels? How can a leader change } \\
\text { his/her KM decision-making process according to different target result levels? Are leaders } \\
\text { fully aware of the consequences of their behaviours and decisions on different levels? } \\
\text { Explorative RAs } \\
\text { Structural and relational capital } \\
\text { How do structural or relational contingencies constraint or enhance leadership behaviours, } \\
\text { social mechanisms to manage knowledge, and, more in general, the KM-leadership } \\
\text { relationship? } \\
\text { Business strategy } \\
\text { How does the alignment between business and KM strategies impact on leadership and its } \\
\text { outcomes? How can leadership intervene to facilitate alignment between operational, KM and } \\
\text { business strategies? } \\
\text { Organisational learning, innovation, productivity, and competitive advantage } \\
\text { How do different types ofleadership perform in terms of organisational routines' evolution and } \\
\text { organisational learning processes? Which are the most powerful group level social mechanisms } \\
\text { that can increase innovation, productivity, profitability and ultimately competitive advantage? }\end{array}$ \\
\hline $\begin{array}{l}\text { BLUE CLUSTER } \\
\text { (SYSTEMIC } \\
\text { APPROACH) }\end{array}$ & $\begin{array}{l}\text { Exploitative RAs } \\
\text { Innovation and productivity } \\
\text { What are the most effective innovation and operative performance indicators through which the } \\
\text { effects of KM practices can effectively be measured? What is the role of leadership in making } \\
\text { KM practices effectively impact on operative performance outcomes? } \\
\text { Explorative RAs } \\
\text { Organisational learning and competitive advantage } \\
\text { How KM practices and its operative outcomes translate into an effective organisational } \\
\text { learning and a sustainable competitive advantage? What is the role of leadership in } \\
\text { transforming KM outcomes into organisational routines and learning, while, in turn, sustaining } \\
\text { the competitive advantage? } \\
\text { Decision making and relational capital } \\
\text { How can KM leadership inform decision-making mechanisms to improve innovation and } \\
\text { operative performances? How do different leadership styles and behaviours impact innovation } \\
\text { and operative performances? } \\
\text { How can KM leadership shape decision-making processes in order to seize external } \\
\text { opportunities for innovation and create an internal learning environment to support the } \\
\text { exploitation of these opportunities? } \\
\text { How can KM leadership shape sophisticated and fast-adapting decision-making processes } \\
\text { which are suitable to address the challenges posed by the } 4.0 \text { digital revolution? }\end{array}$ \\
\hline $\begin{array}{l}\text { GREEN } \\
\text { CLUSTER } \\
\text { (CONTEXTUAL } \\
\text { APPROACH) }\end{array}$ & $\begin{array}{l}\text { Exploitative RAs } \\
\text { Competitive advantage } \\
\text { Which leadership behaviours most effectively contribute to the interplay between KM and } \\
\text { entrepreneurial renewal (corporate entrepreneurship) or corporate governance? } \\
\text { Which KM leadership behaviours most effectively contribute to strategic management and, in } \\
\text { turn, to a competitive advantage? } \\
\text { Explorative RAs } \\
\text { Productivity } \\
\text { How can leadership adapt KM systems and practices to diverse knowledge regimes in terms of } \\
\text { knowledge and capital intensity or knowledge-driven competition or type of knowledge that is } \\
\text { most valuable, in order to positively impact on the operative dimensions of the firm } \\
\text { performance? }\end{array}$ \\
\hline $\begin{array}{l}\text { YELLOW } \\
\text { CLUSTER } \\
\text { (CULTURAL } \\
\text { APPROACH) }\end{array}$ & $\begin{array}{l}\text { Exploitative RAs } \\
\text { Knowledge sharing } \\
\text { How does leadership effectively influence quality and quantity of KS practices? Which are the } \\
\text { most effective leadership behaviours in order to develop and signal the organisational } \\
\text { importance of KM and KS practices and create a supportive internal environment and culture } \\
\text { for these practices? } \\
\text { Business strategy }\end{array}$ \\
\hline
\end{tabular}




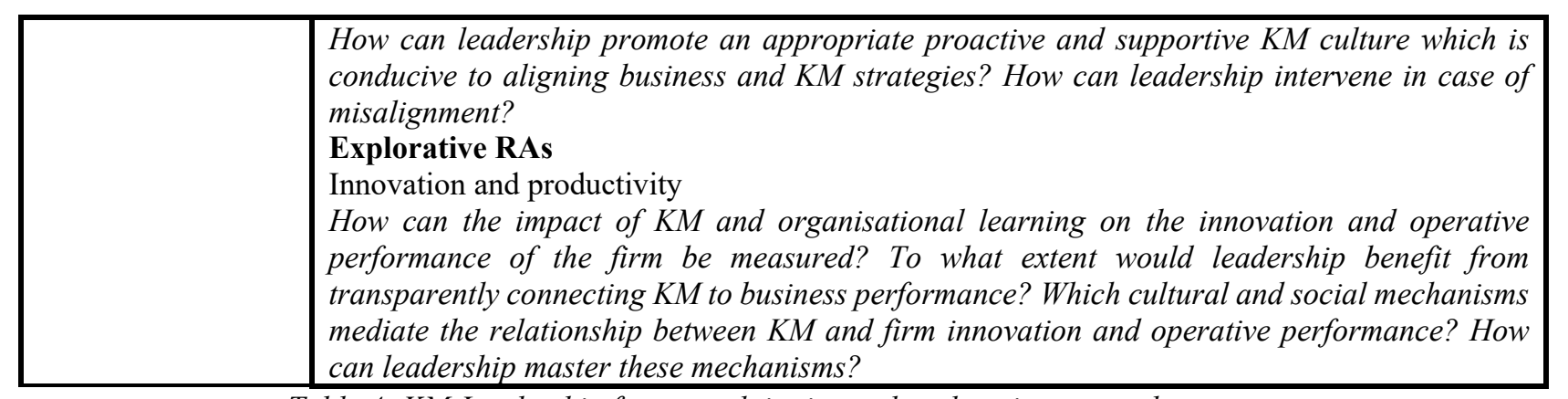

Table 4- KM-Leadership future exploitative and explorative research avenues

\subsection{Mastering social aspects to promote KM}

The cluster focuses on leader behaviours, decision-making processes and leadership styles and how these factors impact on the relational dynamics of social units and groups. An area that has been little explored concerns how leadership behaviours, and human resource management practices should differ according to the level, individual or group one, at which the analysis is carried out (e.g. Dong et al., 2017; Mittal and Dhar, 2015). Precisely this gap could explain why some studies do not find a direct relation between KM and leadership (e.g. Masa'deh et al., 2016). For this reason, researchers are encouraged to better clarify at which research level their study is conducted, more deeply discern how the leadership impacts on each of these two levels, and investigate the effects resulting from the interactions between them. Summarising this gap may open a set of exploitative RAs aimed at investigating research questions such as: how does leadership, in general and according to diverse leadership styles, differently influence KM activity outcomes at individual and group levels? How can a leader change his/her KM decision-making process according to different target result levels? Are leaders fully aware of the consequences of their behaviours and decisions on different levels? With regard to the explorative RAs, the cluster, though delving into KM mechanisms and dynamics at the level of social groups, fails to explore several contextual dimensions in which these groups are embedded and the consequences of these dimensions on leaders' behaviours. More precisely, there are at least two categories of overlooked contextual conditions. One is related to IC composition and development. In fact, this cluster deeply investigates the structural capital in terms of existing or resulting KM managerial culture, but it only analyses the remaining structural aspects (such as intellectual property, IT system, and organisational structure) and the external and relational contextual aspects (e.g. the distribution channels' structure and the level of brand awareness possessed by the firm) on the surface. As these aspects may significantly bind team performance (Valmohammadi and Ahmadi, 2014) and affect the potential intervention of leadership, researchers should pay more attention to them and to their influence on leadership behaviours and the resulting KM social mechanisms and dynamics. Summarising: how do structural or relational contingencies constraint or enhance leadership behaviours, social mechanisms to manage knowledge, and, more in general, the KM-leadership relationship? The second category of overlooked contextual conditions is related to the degree of alignment among business and KM strategies and its impact on leadership effectiveness. In fact, in case of misalignment, any intervention of the leader may result in ad hoc solutions, providing only temporary benefits and a little impact on several KM outcomes and ultimately on competitive advantage (Heisig et al., 2016). This aspect is especially relevant in light of the 4.0 digital revolution paradigm, which is allowing KM systems to evolve very quickly, for example in the direction of the digitalisation of the 'objects' involved in a production process (such as machineries, inputs and outputs) and the real time replica of living or non-living physical entities (digital twin technologies), with very strong advantages for employees when assessing advancements and status of the production (Fakhar-Manesh et al., 2019). These great opportunities also imply that operational and production policies may evolve more rapidly than KM strategies and the latter, in turn, may evolve more rapidly than business strategies. Accordingly: how does the alignment between business and KM strategies impact on leadership and its outcomes? How can leadership intervene to facilitate alignment between operational, KM and business strategies? 


\subsection{Leveraging leadership to develop effective KM systems}

The blue cluster investigates the systemic and performance aspects of the KM-Leadership relationship by mainly looking into the themes related to $\mathrm{KM}$ outcomes (such as innovation, productivity, structural capital) and KM activities (such as KS practices). This cluster is strongly focused on justifying the efforts for the development of a KM system, understanding its main consequences and advantages (Heisig et al., 2016), and investigating how to effectively lead this development. The KM benefits are generally captured in terms of intellectual property capital, new product development, and, more generally, innovation outcomes. Nevertheless, the full set of correlations between KM and firm performance is far to be clearly established (Bontis and Fitz-enz, 2002). In particular, researchers should gauge which KM operative measures are appropriate to catch the real impact of KM practices on specific innovation and operative performance dimensions; as well as in which measure leadership behaviours influence the relationship between KM practices and operative performances. Accordingly, some interesting exploitative research questions could be: what are the most effective innovation and operative performance indicators through which the effects of KM practices can effectively be measured? What is the role of leadership in making KM practices effectively impact on operative performance outcomes?

This cluster does not delve into how KM practices and its operative results (in terms of innovation, patents, productivity, etc.) can be capitalised and translated into effective organisational learning routines and, in turn, a competitive advantage sustainable over time. Furthermore, again, how leadership influences the relationship between KM practices and a sustainable competitive advantage still remains scarcely explored. For example, more attention should be paid to the leadership and routinisation of KM practices conducting to innovation as well as to how specific product or process innovation results or patents could stimulate $\mathrm{KC}$ processes aimed at enlarging the knowledge patrimony of the firm (Nonaka et al., 2000). Accordingly, the following explorative RAs question could be investigated: how KM practices and its operative outcomes translate into an effective organisational learning and a sustainable competitive advantage? What is the role of leadership in transforming KM outcomes into organisational routines and learning, while, in turn, sustaining the competitive advantage? Furthermore, what is missing is a full acknowledgment of the measure in which this relationship between KM and its operative performance dimensions is influenced by the adoption of different leadership decision-making approaches and behavioural styles. This gap may open a further set of explorative RAs aimed at investigating research questions such as: how can KM leadership inform decision-making mechanisms to improve innovation and operative performances? How do different leadership styles and behaviours impact innovation and operative performances? Another unexplored research area regards how leadership can impact the decision-making process in order to effectively get access to the external opportunities, for example those resulting from the firm embeddedness into a network of companies or of knowledge workers (Allen et al., 2016), as well as to stimulate the diffuse and collective involvement and effort of all workers and the supportive internal environment that are necessary to fully exploit these opportunities (Pérez López et al., 2004). For this reason, attention should be paid to the social mechanisms that leadership could trigger and manage in order to promote outward-looking KM routines for innovation (Santoro et al., 2018) and develop proper internal organisational routines suitable to actualise and implement the external opportunities (Dooley and Kirk, 2007). In sum: how can KM leadership shape decision-making processes in order to seize external opportunities for innovation and create an internal learning environment to support the exploitation of these opportunities?

\subsection{Leading the adaptation of KM systems to different knowledge and strategic regimes}

The green cluster, with its contextual approach, is the most comprehensive in terms of covered KM themes. It almost fully covers all KM inputs, activities, and outcomes. Most of its contributions investigate the relationship between the management of knowledge and the competitive advantage of the firm. Many studies offer insights about the fact that KM does not relate only to tactical or 
operational issues but also to strategic decisions and concerns (Caridi-Zahavi et al., 2016): for example, it is crucial in order to sustain a continuous entrepreneurial renewal (Dess et al., 2003), or to inclusively consider stakeholders' interests (Van Ees et al., 2009). However, little investigation has been carried on which specific KM leadership behaviours and social mechanisms could effectively contribute to these strategic management decisions and processes. More particularly, the current literature seems to simply call KM leadership to support and monitor KM and business strategies (von Krogh et al., 2012), without giving any specific directions on which could be the most effective leadership behavioural approaches. Thus, the following exploitative research questions: which leadership behaviours most effectively contribute to the interplay between KM and entrepreneurial renewal (corporate entrepreneurship) or corporate governance? Furthermore, little investigation has been carried on the KM-strategic management relationship (Heisig et al., 2016). Thus, which KM leadership behaviours most effectively contribute to strategic management and, in turn, to a competitive advantage?

Furthermore, some relevant contextual dimensions and their influence on the relationship between $\mathrm{KM}$ and the operative dimensions (productivity and profitability) of the firm performance are yet to be analysed. In particular, the existing literature does not investigate whether and how the KM effects on the operative dimensions of the firm performance could be influenced by factors such as the level of knowledge or capital intensity of the context (Lee et al., 2018), or the level of knowledge-driven competition, i.e. a higher or lower external pressure to adopt KM, or the type of knowledge (i.e. tacit or explicit) that is most valuable for a certain business context (Heisig et al., 2016). Even less is known about how leadership can impact on these factors. Thus, it is reasonable to propose the following explorative research: how can leadership adapt KM systems and practices to diverse knowledge regimes in terms of knowledge and capital intensity or knowledge-driven competition or type of knowledge that is most valuable, in order to positively impact on the operative dimensions of the firm performance?

\subsection{Developing and exploiting the potential of a supportive KM culture}

Finally, the yellow cluster considers the KM-leadership relationship adopting a comprehensive perspective, with the most inquired KM themes being business strategy, inputs, and activities. Its cultural approach clearly links and harmonises the principal orientations of the business strategy to the KM process and effectively connect the human and relational aspects with the necessity of KM practices routinisation (Flores et al., 2012). Central to this approach is the possibility to structure and develop effective interactions to share knowledge internally. Nevertheless, the quality and quantity of these interactions are quite hard to manage and not always easily measurable (Kulkarni et al., 2006; Zboralski, 2009). With this regard, further studies should investigate how leadership behaviours could effectively stimulate and orientate the frequency and the deepness of KS practices. Furthermore, the real organisational use of the shared knowledge is also relevant. In fact, if workers perceive no value in engaging in KS practice, they will not (Seba et al., 2012). Thus, an exploitative RA could be aimed at investigating the following research questions: how does leadership effectively influence quality and quantity of KS practices? Which are the most effective leadership behaviours in order to develop and signal the organisational importance of KM and KS practices and create a supportive internal environment and culture for these practices?

Even though it covers almost all leadership-KM themes, the yellow cluster does not propose any specific indicator able to highlight the impact of a supporting culture for KM and an effective organisational learning on the innovation and operative performance of the firm. Indeed, many studies find that KM outcomes are achieved when an organisational learning has occurred (e.g. Flores et al., 2012) or the overall competitive advantage is enhanced (Pérez López et al., 2004; von Krogh et al., 2012). Furthermore, there is not deep investigation about how individual or group level results mediate the relationship between KM culture and firm performance. Therefore, these findings could expand by developing a set of appropriate performance indicators to measure the real impact of KM 
on the innovation and operative performance of the firm and to investigate which social leverages and mechanisms are necessary to effectively translate organisational learning into operative performance (von Krogh et al., 2012). Thus, it is reasonable to propose the following explorative research: how can the impact of KM and organisational learning on the innovation and operative performance of the firm be measured? To what extent would leadership benefit from transparently connecting KM to business performance? Which cultural and social mechanisms mediate the relationship between KM and firm innovation and operative performance? How can leadership master these mechanisms?

\section{Conclusion}

Though many contributions have thoroughly assessed and systematised the knowledge about KM (e.g., Heisig et al., 2016; Inken, 2016), to our best knowledge, this is the first study that maps and systematically analyses the literature concerning the relationship between the two fields.

We also propose a tentative research agenda with: a) a set of exploitative RAs, i.e. directions that despite having already been investigated, may still present an interesting potential of further development and capitalisation; b) a set of explorative RAs, i.e. directions that have been investigated either not or to a very limited extent.

This paper has some limitations. First, the application of a protocol to select the papers to be included in our review may have been biased by the interpretation of the researcher. In line with the best methodological practices (e.g. Tranfield et al., 2003), also applied to bibliometric KM studies (e.g. Fakhar-Manesh et al., 2019; Gaviria-Marin et al., 2019), we addressed this concern by using a very clear set of including criteria and performing multiple human subject selection processes whose reliability was confirmed by the fact that Krippendorf's Alpha coefficient always resulted $>0.80$. A second limitation lies in the decision of using Scopus as reference database. This second limitation was addressed by cross-cheeking the search string results on Web of Science and EBSCO Business Premier databases. Our hope is that this work will trigger a new debate on the role of leadership in shaping KM systems with regard to different conceptual levels (strategy, KM inputs, KM activities, KM outputs and outcomes).

\section{References}

Allen, T.J., Gloor, P.A., Fronzetti-Colladon, A., Woerner, S.L., \& Raz, O. (2016). The power of reciprocal knowledge sharing relationships for startup success. Journal of Small Business and Enterprise Development, 23(3), 636-651.

Appio, F.P., Cesaroni, F., \& Di Minin, A. (2014). Visualizing the structure and bridges of the intellectual property management and strategy literature: a document co-citation analysis. Scientometrics, 101(1), 623-661.

Bavik, Y.L., Tang, P.M., Shao, R., \& Lam, L.W. (2018). Ethical leadership and employee knowledge sharing: Exploring dual-mediation paths. Leadership Quarterly, 29(2), 322-332.

Bhatnagar, V.R. (2017). Systemic development of leadership: action research in an Indian manufacturing organization. Systemic Practice and Action Research, 30(4), 339-376.

Birasnav, M. (2014). Knowledge management and organizational performance in the service industry: The role of transformational leadership beyond the effects of transactional leadership. Journal of Business Research, 67(8), 1622-1629.

Birnbaum D., Gretsinger K., Antonio M.G., Loewen E., \& Lacroix P. (2018). Revisiting public health informatics: patient privacy concerns, International Journal of Health Governance, 23(2), 149159.

Bligh, M.C., Pearce, C.L., \& Kohles, J.C. (2006). The importance of self- and shared leadership in 
team-based knowledge work: A meso-level model of leadership dynamics. Journal of Managerial Psychology, 21(4), 296-318.

Bolisani, E., \& Scarso, E. (2014). The place of communities of practice in knowledge management studies: a critical review, Journal of Knowledge Management, 18(2), 366-381.

Bontis, N., \& Fitz-enz, J. (2002). Intellectual capital ROI: A causal map of human capital antecedents and consequents. Journal of Intellectual Capital, 3(3), 223-247.

Brewster, C., Sparrow, P., \& Harris, H. (2005). Towards a new model of globalizing HRM. International Journal of Human Resource Management, 16(6), 949-970.

Caputo, A., Marzi, G., Pellegrini, M.M., \& Rialti, R. (2018). Conflict management in family businesses: A bibliometric analysis and systematic literature review. International Journal of Conflict Management, 29(4), 519-542.

Caridi-Zahavi, O., Carmeli, A., \& Arazy, O. (2016). The influence of CEOs' visionary innovation leadership on the performance of high-technology ventures: The mediating roles of connectivity and knowledge integration. Journal of Product Innovation Management, 33(3), 356-376.

Carmeli, A., Gelbard, R., \& Reiter-Palmon, R. (2013). Leadership, Creative Problem-Solving Capacity, and Creative Performance: The Importance of Knowledge Sharing. Human Resource Management, 52(1), 95-121.

Chuang, C. H., Jackson, S.E., \& Jiang, Y. (2016). Can Knowledge-Intensive Teamwork Be Managed? Examining the Roles of HRM Systems, Leadership, and Tacit Knowledge. Journal of Management, 42(2), 524-554.

Cillo, V., Petruzzelli, A. M., Ardito, L., \& Del Giudice, M. (2019). Understanding sustainable innovation: A systematic literature review. Corporate Social Responsibility and Environmental Management, 26(5), 1012-1025.

Corfield, A., \& Paton, R. (2016). Investigating knowledge management: can KM really change organisational culture? Journal of Knowledge Management, 20(1), 88-103.

Dess, G.G., Ireland, R.D., Zahra, S.A., Floyd, S.W., Janney, J.J., \& Lane, P.J. (2003). Emerging issues in corporate entrepreneurship. Journal of Management, 29(3), 351-378.

Donate, M.J., \& Sánchez de Pablo, J.D. (2015). The role of knowledge-oriented leadership in knowledge management practices and innovation. Journal of Business Research, 68(2), 360370.

Dong, Y., Bartol, K.M., Zhang, Z.X., \& Li, C. (2017). Enhancing employee creativity via individual skill development and team knowledge sharing: Influences of dual-focused transformational leadership. Journal of Organizational Behavior, 38(3), 439-458.

Dooley, L., \& Kirk, D. (2007). University-industry collaboration: Grafting the entrepreneurial paradigm onto academic structures. European Journal of Innovation Management, 10(3), 316332.

Fakhar-Manesh M., Pellegrini M.M., Marzi G., \& Dabic M. (2019). Knowledge management in the fourth industrial revolution: Mapping the literature and scoping future avenues. IEEE Transactions on Engineering Management, online first, DOI:10.1109/TEM.2019.2963489.

Falagas, M.E., Pitsouni, E.I., Malietzis, G.A., \& Pappas, G. (2008). Comparison of PubMed, Scopus, web of science, and Google scholar: strengths and weaknesses. The FASEB journal, 22(2), 338342.

Flores, L.G., Zheng, W., Rau, D., \& Thomas, C.H. (2012). Organizational Learning: Subprocess Identification, Construct Validation, and an Empirical Test of Cultural Antecedents. Journal of Management, 38(2), 640-667.

Gaviria-Marin, M., Merigó, J.M., \& Baier-Fuentes, H. (2019). Knowledge management: A global examination based on bibliometric analysis. Technological Forecasting and Social Change, 140, 194-220.

$\mathrm{Gu}$, Y. (2004). Global knowledge management research: A bibliometric analysis. Scientometrics, 61(2), 171-190.

Ho, C.T. (2009). The relationship between knowledge management enablers and 
performance. Industrial Management \& Data Systems, 109(1), 98-117.

Inkinen, H. (2016). Review of empirical research on knowledge management practices and firm performance. Journal of Knowledge Management, 20(2), 230-257.

Jacobs, G., Van Witteloostuijn, A., \& Christe-Zeyse, J. (2013). A theoretical framework of organizational change. Journal of Organizational Change Management, 26(5), 772-792.

Karahanna, E., \& Preston, D. (2013). The effect of social capital of the relationship between the CIO and top management team on firm performance. Journal of Management Information Systems, $30(1), 15-55$.

Kulkarni, U.R., Ravindran, S., \& Freeze, R. (2006). A knowledge management success model: Theoretical development and empirical validation. Journal of Management Information Systems, 23(3), 309-347.

Lee, A., Willis, S., \& Tian, A.W. (2018). Empowering leadership: A meta-analytic examination of incremental contribution, mediation, and moderation. Journal of Organizational Behavior, $39(3), 306-325$.

Lin, H.E., \& McDonough III, E.F. (2011). Investigating the role of leadership and organizational culture in fostering innovation ambidexterity. IEEE Transactions on Engineering Management, 58(3), 497-509.

Ma, Z., Qi, L., \& Wang, K. (2008). Knowledge sharing in Chinese construction project teams and its affecting factors, Chinese Management Studies, 2(2), 97-108.

Marcinkus-Murphy, W. (2012). Reverse mentoring at work: Fostering cross-generational learning and developing millennial leaders. Human Resource Management, 51(4), 549-573.

Martins, V.W.B., Rampasso, I.S., Anholon, R., Quelhas, O.L.G., \& Leal-Filho, W. (2019). Knowledge management in the context of sustainability: Literature review and opportunities for future research. Journal of Cleaner Production, 229, 489-500.

Masa'deh, R., Obeidat, B.Y., \& Tarhini, A. (2016). A Jordanian empirical study of the associations among transformational leadership, transactional leadership, knowledge sharing, job performance, and firm performance: A structural equation modelling approach. Journal of Management Development, 35(5), 681-705.

Mingers, J. (2008). Management knowledge and knowledge management: realism and forms of truth. Knowledge Management Research \& Practice, 6(1), 62-76.

Mittal, S., \& Dhar, R.L. (2015). Transformational leadership and employee creativity: mediating role of creative self-efficacy and moderating role of knowledge sharing. Management Decision, 53(5), 894-910.

Natalicchio, A., Ardito, L., Savino, T., \& Albino, V. (2017). Managing knowledge assets for open innovation: a systematic literature review. Journal of Knowledge Management, 21(6), 13621383.

Nonaka, I. (1994). A dynamic theory of organizational knowledge creation. Organization science, 5(1), 14-37.

Nonaka, I., Toyama, R., \& Konno, N. (2000). SECI, Ba and Leadership: A Unified Model of Dynamic Knowledge Creation. Long Range Planning, 33(1), 5-34.

Pan, S.L., \& Scarbrough, H. (1998). A Socio-Technical View of Knowledge Sharing at Buckman Laboratories. Journal of Knowledge Management, 2(1), 55-66.

Pan, S.L., \& Scarbrough, H. (1999). Knowledge management in practice: An exploratory case study. Technology Analysis and Strategic Management, 11(3), 359-374.

Pérez-López, J.M., Montes Peon, C.J., \& Vazquez Ordas J.C. (2004), Managing knowledge: the link between culture and organizational learning, Journal of Knowledge Management, 8(6), 93-104.

Ponzi, L.J. (2002). The intellectual structure and interdisciplinary breadth of knowledge management: A bibliometric study of its early stage of development. Scientometrics, 55(2), 259-272.

Rashman, L., Withers, E., \& Hartley, J. (2009). Organizational learning and knowledge in public service organizations: A systematic review of the literature. International Journal of Management Reviews, 11(4), 463-494. 
Raudeliūnienè, J., Davidavičienė, V. \& Jakubavičius, A. (2018). Knowledge management process model. Entrepreneurship and Sustainability Issues, 5(3), 542-554.

Santoro, G., Vrontis, D., Thrassou, A., \& Dezi, L. (2018). The Internet of Things: Building a knowledge management system for open innovation and knowledge management capacity. Technological Forecasting and Social Change, 136, 347-354.

Seba, I., Rowley, J., \& Delbridge, R. (2012). Knowledge sharing in the Dubai Police Force. Journal of Knowledge Management, 16(1), 114-128.

Serenko, A., Bontis, N., Booker, L., Sadeddin, K., \& Hardie, T. (2010). A scientometric analysis of knowledge management and intellectual capital academic literature (1994-2008), Journal of Knowledge Management, 14(1), 3-23.

Sievert, H., \& Scholz, C. (2017). Engaging employees in (at least partly) disengaged companies. Results of an interview survey within about 500 German corporations on the growing importance of digital engagement via internal social media. Public Relations Review, 43(5), 894-903.

Singh, S.K. (2008). Role of leadership in knowledge management: A study. Journal of Knowledge Management, 12(4), 3-15.

Smith, M., Busi, M., Ball, P., \& Van Der Meer, R. (2008). Factors influencing an organisation's ability to manage innovation: A structured literature review and conceptual model. International Journal of Innovation Management, 12(4), 655-676.

Srivastava, A., Bartol, K.M., \& Locke, E.A. (2006). Empowering leadership in management teams: Effects on knowledge sharing, efficacy, and performance. Academy of Management Journal, 49(6), 1239-1251.

Todeschini, R., \& Baccini, A. (2016). Handbook of Bibliometric Indicators: Quantitative Tools for Studying and Evaluating Research. Wiley-VCH, Weinheim, Germany

Tranfield, D., Denyer, D., \& Smart, P. (2003). Towards a methodology for developing evidenceinformed management knowledge by means of systematic review. British journal of management, 14(3), 207-222.

Valmohammadi, C., \& Ahmadi, M. (2015). The impact of knowledge management practices on organizational performance: A balanced scorecard approach. Journal of Enterprise Information Management, 28(1), 131-159.

Van Eck, N.J., \& Waltman, L. (2010). Software survey: VOSviewer, a computer program for bibliometric mapping. Scientometrics, 84(2), 523-538.

Van Eck, N.J., \& Waltman, L. (2014). Visualizing bibliometric networks. In Ding, Y., Rousseau, R., \& Wolfram, D. (eds) Measuring scholarly impact (pp. 285-320). Springer, Cham UK.

Van Ees, H., Gabrielsson, J., \& Huse, M. (2009). Toward a behavioral theory of boards and corporate governance. Corporate Governance: An International Review, 17(3), 307-319.

Vera, D., \& Crossan, M. (2004). Strategic leadership and organizational learning. Academy of management review, 29(2), 222-240.

von Krogh, G., Nonaka, I., \& Rechsteiner, L. (2012). Leadership in organizational knowledge creation: A review and framework. Journal of Management Studies, 49(1), 240-277.

Wee, J.C.N., \& Chua, A.Y.K. (2013). The peculiarities of knowledge management processes in SMEs: The case of Singapore. Journal of Knowledge Management, 17(6), 958-972.

Xue, Y., Bradley, J., \& Liang, H. (2011). Team climate, empowering leadership, and knowledge sharing. Journal of Knowledge Management, 15(2), 299-312.

Yahya, S., \& Goh, W.K. (2002). Managing human resources toward achieving knowledge management. Journal of Knowledge Management, 6(5), 457-468.

Yang (2010). Antecedents and consequences of knowledge sharing in international tourist hotels. International Journal of Hospitality Management, 29(1), 42-52.

Yang, J.T. (2007). Knowledge sharing: Investigating appropriate leadership roles and collaborative culture. Tourism Management, 28(2), 530-543.

Zboralski, K. (2009). Antecedents of knowledge sharing in communities of practice. Journal of Knowledge Management, 13(3), 90-101. 
Zupic, I., \& Čater, T. (2015). Bibliometric methods in management organization. Organizational Research Methods, 18(3), 429-472.

\section{Appendix 1 - Full dataset (papers are ordered according to the total citation numbers) object of the bibliometric analysis.}

\begin{tabular}{|c|c|c|c|c|c|}
\hline$\#$ & Authors & Title & Year & Journal & TC \\
\hline 1 & $\begin{array}{l}\text { Nonaka I., Toyama } \\
\text { R., Konno N. }\end{array}$ & $\begin{array}{l}\text { SECI, Ba and Leadership: A Unified } \\
\text { Model of Dynamic Knowledge Creation }\end{array}$ & 2000 & Long Range Planning & 1743 \\
\hline 2 & $\begin{array}{l}\text { Srivastava A., } \\
\text { Bartol K.M., Locke } \\
\text { E.A. }\end{array}$ & $\begin{array}{l}\text { Empowering leadership in management } \\
\text { teams: Effects on knowledge sharing, } \\
\text { efficacy, and performance }\end{array}$ & 2006 & $\begin{array}{l}\text { Academy of } \\
\text { Management Journal }\end{array}$ & 598 \\
\hline 3 & $\begin{array}{l}\text { Kulkarni U.R., } \\
\text { Ravindran S., } \\
\text { Freeze R. }\end{array}$ & $\begin{array}{l}\text { A knowledge management success model: } \\
\text { Theoretical development and empirical } \\
\text { validation }\end{array}$ & 2006 & $\begin{array}{l}\text { Journal of Management } \\
\text { Information Systems }\end{array}$ & 389 \\
\hline 4 & $\begin{array}{l}\text { Dess G.G., Ireland } \\
\text { R.D., Zahra S.A., } \\
\text { Floyd S.W., Janney } \\
\text { J.J., Lane P.J. }\end{array}$ & $\begin{array}{l}\text { Emerging issues in corporate } \\
\text { entrepreneurship }\end{array}$ & 2003 & Journal of Management & 342 \\
\hline 5 & $\begin{array}{l}\text { Bontis N., Fitz-enz } \\
\text { J. }\end{array}$ & $\begin{array}{l}\text { Intellectual capital ROI: A causal map of } \\
\text { human capital antecedents and } \\
\text { consequents }\end{array}$ & 2002 & $\begin{array}{l}\text { Journal of Intellectual } \\
\text { Capital }\end{array}$ & 321 \\
\hline 6 & $\begin{array}{l}\text { Sarin S., } \\
\text { McDermott C. }\end{array}$ & $\begin{array}{l}\text { The Effect of Team Leader Characteristics } \\
\text { on Learning, Knowledge Application, and } \\
\text { Performance of Cross-functional New } \\
\text { Product Development Teams }\end{array}$ & 2003 & Decision Sciences & 263 \\
\hline 7 & $\begin{array}{l}\text { Bierly III P.E., } \\
\text { Kessler E.H., } \\
\text { Christensen E.W. }\end{array}$ & $\begin{array}{l}\text { Organizational learning, knowledge and } \\
\text { wisdom }\end{array}$ & 2000 & $\begin{array}{l}\text { Journal of } \\
\text { Organizational Change } \\
\text { Management }\end{array}$ & 263 \\
\hline 8 & $\begin{array}{l}\text { Bassellier G., } \\
\text { Benbasat I., Reich } \\
\text { B.H. }\end{array}$ & $\begin{array}{l}\text { The Influence of Business Managers' IT } \\
\text { Competence on Championing IT }\end{array}$ & 2003 & $\begin{array}{l}\text { Information Systems } \\
\text { Research }\end{array}$ & 255 \\
\hline 9 & Takeishi A. & $\begin{array}{l}\text { Knowledge partitioning in the interfirm } \\
\text { division of labor: The case of automotive } \\
\text { product development }\end{array}$ & 2002 & Organization Science & 231 \\
\hline 10 & $\begin{array}{l}\text { Yahya S., Goh W.- } \\
\text { K. }\end{array}$ & $\begin{array}{l}\text { Managing human resources toward } \\
\text { achieving knowledge management }\end{array}$ & 2002 & $\begin{array}{l}\text { Journal of Knowledge } \\
\text { Management }\end{array}$ & 225 \\
\hline 11 & $\begin{array}{l}\text { Pan S.L., } \\
\text { Scarbrough H. }\end{array}$ & $\begin{array}{l}\text { Knowledge management in practice: An } \\
\text { exploratory case study }\end{array}$ & 1999 & $\begin{array}{l}\text { Technology Analysis } \\
\text { and Strategic } \\
\text { Management }\end{array}$ & 201 \\
\hline 12 & $\begin{array}{l}\text { Kim W.C., } \\
\text { Mauborgne R. }\end{array}$ & $\begin{array}{l}\text { Fair process: managing in the knowledge } \\
\text { economy. }\end{array}$ & 1997 & $\begin{array}{l}\text { Harvard business } \\
\text { review }\end{array}$ & 199 \\
\hline 13 & $\begin{array}{l}\text { Kelloway E.K., } \\
\text { Barling J. }\end{array}$ & $\begin{array}{l}\text { Knowledge work as organizational } \\
\text { behavior }\end{array}$ & 2000 & $\begin{array}{l}\text { International Journal of } \\
\text { Management Reviews }\end{array}$ & 189 \\
\hline 14 & Yang J.-T. & $\begin{array}{l}\text { Knowledge sharing: Investigating } \\
\text { appropriate leadership roles and } \\
\text { collaborative culture }\end{array}$ & 2007 & Tourism Management & 180 \\
\hline 15 & $\begin{array}{l}\text { Pérez López S., } \\
\text { Manuel Montes } \\
\text { Peón J., José } \\
\text { Vázquez Ordás C. }\end{array}$ & $\begin{array}{l}\text { Managing knowledge: The link between } \\
\text { culture and organizational learning }\end{array}$ & 2004 & $\begin{array}{l}\text { Journal of Knowledge } \\
\text { Management }\end{array}$ & 177 \\
\hline 16 & $\begin{array}{l}\text { Pan S.L., } \\
\text { Scarbrough H. }\end{array}$ & $\begin{array}{l}\text { A Socio-Technical View of Knowledge } \\
\text { Sharing at Buckman Laboratories }\end{array}$ & 1998 & $\begin{array}{l}\text { Journal of Knowledge } \\
\text { Management }\end{array}$ & 157 \\
\hline 17 & $\begin{array}{l}\text { Hung Y.-C., Huang } \\
\text { S.-M., Lin Q.-P., } \\
\text { Tsai M.-L. }\end{array}$ & $\begin{array}{l}\text { Critical factors in adopting a knowledge } \\
\text { management system for the } \\
\text { pharmaceutical industry }\end{array}$ & 2005 & $\begin{array}{l}\text { Industrial Management } \\
\text { and Data Systems }\end{array}$ & 155 \\
\hline 18 & $\begin{array}{l}\text { Yeh Y.-J., Lai S.- } \\
\text { Q., Ho C.-T. }\end{array}$ & $\begin{array}{l}\text { Knowledge management enablers: A case } \\
\text { study }\end{array}$ & 2006 & $\begin{array}{l}\text { Industrial Management } \\
\text { and Data Systems }\end{array}$ & 154 \\
\hline
\end{tabular}




\begin{tabular}{|c|c|c|c|c|c|}
\hline 19 & $\begin{array}{l}\text { Skyrme D., Amidon } \\
\text { D. }\end{array}$ & The Knowledge Agenda & 1997 & $\begin{array}{l}\text { Journal of Knowledge } \\
\text { Management }\end{array}$ & 153 \\
\hline 20 & $\begin{array}{l}\text { von Krogh G., } \\
\text { Nonaka I., } \\
\text { Rechsteiner L. }\end{array}$ & $\begin{array}{l}\text { Leadership in organizational knowledge } \\
\text { creation: A review and framework }\end{array}$ & 2012 & $\begin{array}{l}\text { Journal of Management } \\
\text { Studies }\end{array}$ & 148 \\
\hline 21 & Ayas K., Zeniuk N. & $\begin{array}{l}\text { Project-based Learning: Building } \\
\text { Communities of Reflective Practitioners }\end{array}$ & 2001 & Management Learning & 139 \\
\hline 22 & $\begin{array}{l}\text { Gumusluǒlu L., } \\
\text { Ilsev A. }\end{array}$ & $\begin{array}{l}\text { Transformational leadership and } \\
\text { organizational innovation: The roles of } \\
\text { internal and external support for } \\
\text { innovation }\end{array}$ & 2009 & $\begin{array}{l}\text { Journal of Product } \\
\text { Innovation Management }\end{array}$ & 129 \\
\hline 23 & $\begin{array}{l}\text { Van Ees H., } \\
\text { Gabrielsson J., } \\
\text { Huse M. }\end{array}$ & $\begin{array}{l}\text { Toward a behavioral theory of boards and } \\
\text { corporate governance }\end{array}$ & 2009 & $\begin{array}{l}\text { Corporate Governance: } \\
\text { An International Review }\end{array}$ & 129 \\
\hline 24 & $\begin{array}{l}\text { Donate M.J., } \\
\text { Sánchez de Pablo } \\
\text { J.D. }\end{array}$ & $\begin{array}{l}\text { The role of knowledge-oriented leadership } \\
\text { in knowledge management practices and } \\
\text { innovation }\end{array}$ & 2015 & $\begin{array}{l}\text { Journal of Business } \\
\text { Research }\end{array}$ & 125 \\
\hline 25 & $\begin{array}{l}\text { Lee P., Gillespie } \\
\text { N., Mann L., } \\
\text { Wearing A. }\end{array}$ & $\begin{array}{l}\text { Leadership and trust: Their effect on } \\
\text { knowledge sharing and team performance }\end{array}$ & 2010 & Management Learning & 125 \\
\hline 26 & $\begin{array}{l}\text { Donate M.J., } \\
\text { Guadamillas F. }\end{array}$ & $\begin{array}{l}\text { Organizational factors to support } \\
\text { knowledge management and innovation }\end{array}$ & 2011 & $\begin{array}{l}\text { Journal of Knowledge } \\
\text { Management }\end{array}$ & 115 \\
\hline 27 & Ho C.-T. & $\begin{array}{l}\text { The relationship between knowledge } \\
\text { management enablers and performance }\end{array}$ & 2009 & $\begin{array}{l}\text { Industrial Management } \\
\text { and Data Systems }\end{array}$ & 115 \\
\hline 28 & $\begin{array}{l}\text { Fullwood R., } \\
\text { Rowley J., } \\
\text { Delbridge R. }\end{array}$ & $\begin{array}{l}\text { Knowledge sharing amongst academics in } \\
\text { UK universities }\end{array}$ & 2013 & $\begin{array}{l}\text { Journal of Knowledge } \\
\text { Management }\end{array}$ & 111 \\
\hline 29 & $\begin{array}{l}\text { Bligh M.C., Pearce } \\
\text { C.L., Kohles J.C. }\end{array}$ & $\begin{array}{l}\text { The importance of self- and shared } \\
\text { leadership in team based knowledge work: } \\
\text { A meso-level model of leadership } \\
\text { dynamics }\end{array}$ & 2006 & $\begin{array}{l}\text { Journal of Managerial } \\
\text { Psychology }\end{array}$ & 111 \\
\hline 30 & $\begin{array}{l}\text { Xue Y., Bradley J., } \\
\text { Liang H. }\end{array}$ & $\begin{array}{l}\text { Team climate, empowering leadership, } \\
\text { and knowledge sharing }\end{array}$ & 2011 & $\begin{array}{l}\text { Journal of Knowledge } \\
\text { Management }\end{array}$ & 107 \\
\hline 31 & Singh S.K. & $\begin{array}{l}\text { Role of leadership in knowledge } \\
\text { management: A study }\end{array}$ & 2008 & $\begin{array}{l}\text { Journal of Knowledge } \\
\text { Management }\end{array}$ & 106 \\
\hline 32 & $\begin{array}{l}\text { Brewster C., } \\
\text { Sparrow P., Harris } \\
\text { H. }\end{array}$ & Towards a new model of globalizing HRM & 2005 & $\begin{array}{l}\text { International Journal of } \\
\text { Human Resource } \\
\text { Management }\end{array}$ & 104 \\
\hline 33 & $\begin{array}{l}\text { Oliver S., Reddy } \\
\text { Kandadi K. }\end{array}$ & $\begin{array}{l}\text { How to develop knowledge culture in } \\
\text { organizations? A multiple case study of } \\
\text { large distributed organizations }\end{array}$ & 2006 & $\begin{array}{l}\text { Journal of Knowledge } \\
\text { Management }\end{array}$ & 103 \\
\hline 34 & Politis J.D. & $\begin{array}{l}\text { The relationship of various leadership } \\
\text { styles to knowledge management }\end{array}$ & 2001 & $\begin{array}{l}\text { Leadership \& } \\
\text { Organization } \\
\text { Development Journal }\end{array}$ & 102 \\
\hline 35 & $\begin{array}{l}\text { Karahanna E., } \\
\text { Preston D. }\end{array}$ & $\begin{array}{l}\text { The effect of social capital of the } \\
\text { relationship between the cio and top } \\
\text { management team on firm performance }\end{array}$ & 2013 & $\begin{array}{l}\text { Journal of Management } \\
\text { Information Systems }\end{array}$ & 95 \\
\hline 36 & $\begin{array}{l}\text { Carmeli A., } \\
\text { Gelbard R., Reiter- } \\
\text { Palmon R. }\end{array}$ & $\begin{array}{l}\text { Leadership, Creative Problem-Solving } \\
\text { Capacity, and Creative Performance: The } \\
\text { Importance of Knowledge Sharing }\end{array}$ & 2013 & $\begin{array}{l}\text { Human Resource } \\
\text { Management }\end{array}$ & 94 \\
\hline 37 & $\begin{array}{l}\text { Eppler M.J., } \\
\text { Sukowski O. }\end{array}$ & $\begin{array}{l}\text { Managing Team Knowledge: Core } \\
\text { Processes, Tools and Enabling Factors }\end{array}$ & 2000 & $\begin{array}{l}\text { European Management } \\
\text { Journal }\end{array}$ & 94 \\
\hline 38 & $\begin{array}{l}\text { Zhang A.Y., Tsui } \\
\text { A.S., Wang D.X. }\end{array}$ & $\begin{array}{l}\text { Leadership behaviors and group creativity } \\
\text { in Chinese organizations: The role of } \\
\text { group processes }\end{array}$ & 2011 & Leadership Quarterly & 93 \\
\hline 39 & $\begin{array}{l}\text { de Vries R.E., } \\
\text { Bakker-Pieper A., } \\
\text { Oostenveld W. }\end{array}$ & $\begin{array}{l}\text { Leadership = communication? The } \\
\text { relations of leaders' communication styles } \\
\text { with leadership styles, knowledge sharing } \\
\text { and leadership outcomes }\end{array}$ & 2010 & $\begin{array}{l}\text { Journal of Business and } \\
\text { Psychology }\end{array}$ & 93 \\
\hline
\end{tabular}




\begin{tabular}{|c|c|c|c|c|c|}
\hline 40 & $\begin{array}{l}\text { Rowley J., Kupiec- } \\
\text { Teahan B., } \\
\text { Leeming E. }\end{array}$ & $\begin{array}{l}\text { Customer community and co-creation: A } \\
\text { case study }\end{array}$ & 2007 & $\begin{array}{l}\text { Marketing Intelligence } \\
\text { and Planning }\end{array}$ & 93 \\
\hline 41 & $\begin{array}{l}\text { Smith M., Busi M., } \\
\text { Ball P., Van Der } \\
\text { Meer R. }\end{array}$ & $\begin{array}{l}\text { Factors influencing an organisation's } \\
\text { ability to manage innovation: A structured } \\
\text { literature review and conceptual model }\end{array}$ & 2008 & $\begin{array}{l}\text { International Journal of } \\
\text { Innovation Management }\end{array}$ & 92 \\
\hline 42 & $\begin{array}{l}\text { Kakabadse N.K., } \\
\text { Kouzmin A., } \\
\text { Kakabadse A. }\end{array}$ & $\begin{array}{l}\text { From tacit knowledge to knowledge } \\
\text { management: Leveraging invisible assets }\end{array}$ & 2001 & $\begin{array}{l}\text { Knowledge and Process } \\
\text { Management }\end{array}$ & 90 \\
\hline 43 & $\begin{array}{l}\text { Mason D., Pauleen } \\
\text { D.J. }\end{array}$ & $\begin{array}{l}\text { Perceptions of knowledge management: A } \\
\text { qualitative analysis }\end{array}$ & 2003 & $\begin{array}{l}\text { Journal of Knowledge } \\
\text { Management }\end{array}$ & 87 \\
\hline 44 & $\begin{array}{l}\text { Chuang C.-H., } \\
\text { Jackson S.E., Jiang } \\
\text { Y. }\end{array}$ & $\begin{array}{l}\text { Can Knowledge-Intensive Teamwork Be } \\
\text { Managed? Examining the Roles of HRM } \\
\text { Systems, Leadership, and Tacit } \\
\text { Knowledge }\end{array}$ & 2016 & Journal of Management & 85 \\
\hline 45 & Mittal S., Dhar R.L. & $\begin{array}{l}\text { Transformational leadership and employee } \\
\text { creativity: Mediating role of creative self- } \\
\text { efficacy and moderating role of } \\
\text { knowledge sharing }\end{array}$ & 2015 & Management Decision & 79 \\
\hline 46 & Dooley L., Kirk D. & $\begin{array}{l}\text { University-industry collaboration: } \\
\text { Grafting the entrepreneurial paradigm onto } \\
\text { academic structures }\end{array}$ & 2007 & $\begin{array}{l}\text { European Journal of } \\
\text { Innovation Management }\end{array}$ & 78 \\
\hline 47 & Birasnav M. & $\begin{array}{l}\text { Knowledge management and } \\
\text { organizational performance in the service } \\
\text { industry: The role of transformational } \\
\text { leadership beyond the effects of } \\
\text { transactional leadership }\end{array}$ & 2014 & $\begin{array}{l}\text { Journal of Business } \\
\text { Research }\end{array}$ & 76 \\
\hline 48 & $\begin{array}{l}\text { Flores L.G., Zheng } \\
\text { W., Rau D., } \\
\text { Thomas C.H. }\end{array}$ & $\begin{array}{l}\text { Organizational Learning: Subprocess } \\
\text { Identification, Construct Validation, and } \\
\text { an Empirical Test of Cultural Antecedents }\end{array}$ & 2012 & Journal of Management & 74 \\
\hline 49 & $\begin{array}{l}\text { Nguyen H.N., } \\
\text { Mohamed S. }\end{array}$ & $\begin{array}{l}\text { Leadership behaviors, organizational } \\
\text { culture and knowledge management } \\
\text { practices: An empirical investigation }\end{array}$ & 2011 & $\begin{array}{l}\text { Journal of Management } \\
\text { Development }\end{array}$ & 73 \\
\hline 50 & $\begin{array}{l}\text { Nambisan S., } \\
\text { Wilemon D. }\end{array}$ & $\begin{array}{l}\text { Software development and new product } \\
\text { development: potentials for cross-domain } \\
\text { knowledge sharing }\end{array}$ & 2000 & $\begin{array}{l}\text { IEEE Transactions on } \\
\text { Engineering } \\
\text { Management }\end{array}$ & 73 \\
\hline 51 & $\begin{array}{l}\text { Hoon Song J., Kolb } \\
\text { J.A., Hee Lee U., } \\
\text { Kyoung Kim H. }\end{array}$ & $\begin{array}{l}\text { Role of transformational leadership in } \\
\text { effective organizational knowledge } \\
\text { creation practices: Mediating effects of } \\
\text { employees' work engagement }\end{array}$ & 2012 & $\begin{array}{l}\text { Human Resource } \\
\text { Development Quarterly }\end{array}$ & 71 \\
\hline 52 & $\begin{array}{l}\text { Marcinkus Murphy } \\
\text { W. }\end{array}$ & $\begin{array}{l}\text { Reverse mentoring at work: Fostering } \\
\text { cross-generational learning and } \\
\text { developing millennial leaders }\end{array}$ & 2012 & $\begin{array}{l}\text { Human Resource } \\
\text { Management }\end{array}$ & 69 \\
\hline 53 & Zboralski K. & $\begin{array}{l}\text { Antecedents of knowledge sharing in } \\
\text { communities of practice }\end{array}$ & 2009 & $\begin{array}{l}\text { Journal of Knowledge } \\
\text { Management }\end{array}$ & 69 \\
\hline 54 & Crawford C.B. & $\begin{array}{l}\text { Effects of transformational leadership and } \\
\text { organizational position on knowledge } \\
\text { management }\end{array}$ & 2005 & $\begin{array}{l}\text { Journal of Knowledge } \\
\text { Management }\end{array}$ & 67 \\
\hline 55 & $\begin{array}{l}\text { Wee J.C.N., Chua } \\
\text { A.Y.K. }\end{array}$ & $\begin{array}{l}\text { The peculiarities of knowledge } \\
\text { management processes in SMEs: The case } \\
\text { of Singapore }\end{array}$ & 2013 & $\begin{array}{l}\text { Journal of Knowledge } \\
\text { Management }\end{array}$ & 65 \\
\hline 56 & $\begin{array}{l}\text { Wei C.C., Choy } \\
\text { C.S., Yew W.K. }\end{array}$ & $\begin{array}{l}\text { Is the Malaysian } \\
\text { telecommunicationindustry ready for } \\
\text { knowledge management implementation? }\end{array}$ & 2009 & $\begin{array}{l}\text { Journal of Knowledge } \\
\text { Management }\end{array}$ & 64 \\
\hline 57 & $\begin{array}{l}\text { Carmeli A., } \\
\text { Atwater L., Levi A. }\end{array}$ & $\begin{array}{l}\text { How leadership enhances employees' } \\
\text { knowledge sharing: The intervening roles } \\
\text { of relational and organizational } \\
\text { identification }\end{array}$ & 2011 & $\begin{array}{l}\text { Journal of Technology } \\
\text { Transfer }\end{array}$ & 63 \\
\hline 58 & $\begin{array}{l}\text { Kets De Vries } \\
\text { M.F.R. }\end{array}$ & $\begin{array}{l}\text { Leadership group coaching in action: The } \\
\text { Zen of creating high performance teams }\end{array}$ & 2005 & $\begin{array}{l}\text { Academy of } \\
\text { Management Executive }\end{array}$ & 63 \\
\hline
\end{tabular}




\begin{tabular}{|c|c|c|c|c|c|}
\hline 59 & $\begin{array}{l}\text { Dong Y., Bartol } \\
\text { K.M., Zhang Z.-X., } \\
\text { Li C. }\end{array}$ & $\begin{array}{l}\text { Enhancing employee creativity via } \\
\text { individual skill development and team } \\
\text { knowledge sharing: Influences of dual- } \\
\text { focused transformational leadership }\end{array}$ & 2017 & $\begin{array}{l}\text { Journal of } \\
\text { Organizational } \\
\text { Behavior }\end{array}$ & 60 \\
\hline 60 & Gloet M. & $\begin{array}{l}\text { Knowledge management and the links to } \\
\text { HRM: Developing leadership and } \\
\text { management capabilities to support } \\
\text { sustainability }\end{array}$ & 2006 & $\begin{array}{l}\text { Management Research } \\
\text { News }\end{array}$ & 59 \\
\hline 61 & $\begin{array}{l}\text { Birasnav M., } \\
\text { Rangnekar S., } \\
\text { Dalpati A. }\end{array}$ & $\begin{array}{l}\text { Transformational leadership and human } \\
\text { capital benefits: The role of knowledge } \\
\text { management }\end{array}$ & 2011 & $\begin{array}{l}\text { Leadership \& } \\
\text { Organization } \\
\text { Development Journal }\end{array}$ & 58 \\
\hline 62 & $\begin{array}{l}\text { Jacobs G., Van } \\
\text { Witteloostuijn A., } \\
\text { Christe-Zeyse J. }\end{array}$ & $\begin{array}{l}\text { A theoretical framework of organizational } \\
\text { change }\end{array}$ & 2013 & $\begin{array}{l}\text { Journal of } \\
\text { Organizational Change } \\
\text { Management }\end{array}$ & 57 \\
\hline 63 & Sutherland I. & $\begin{array}{l}\text { Arts-based methods in leadership } \\
\text { development: Affording aesthetic } \\
\text { workspaces, reflexivity and memories } \\
\text { with momentum }\end{array}$ & 2013 & Management Learning & 56 \\
\hline 64 & $\begin{array}{l}\text { Badri M.A., Selim } \\
\text { H., Alshare K., } \\
\text { Grandon E.E., } \\
\text { Younis H., Abdulla } \\
\text { M. }\end{array}$ & $\begin{array}{l}\text { The Baldrige education criteria for } \\
\text { performance excellence framework: } \\
\text { Empirical test and validation }\end{array}$ & 2006 & $\begin{array}{l}\text { International Journal of } \\
\text { Quality and Reliability } \\
\text { Management }\end{array}$ & 54 \\
\hline 65 & Politis J.D. & $\begin{array}{l}\text { Transformational and transactional } \\
\text { leadership enabling (disabling) knowledge } \\
\text { acquisition of self-managed teams: the } \\
\text { consequences for performance }\end{array}$ & 2002 & $\begin{array}{l}\text { Leadership \& } \\
\text { Organization } \\
\text { Development Journal }\end{array}$ & 54 \\
\hline 66 & $\begin{array}{l}\text { Martins E.C., } \\
\text { Meyer H.W.J. }\end{array}$ & $\begin{array}{l}\text { Organizational and behavioral factors that } \\
\text { influence knowledge retention }\end{array}$ & 2012 & $\begin{array}{l}\text { Journal of Knowledge } \\
\text { Management }\end{array}$ & 53 \\
\hline 67 & Yang J.-T. & $\begin{array}{l}\text { Antecedents and consequences of } \\
\text { knowledge sharing in international tourist } \\
\text { hotels }\end{array}$ & 2010 & $\begin{array}{l}\text { International Journal of } \\
\text { Hospitality } \\
\text { Management }\end{array}$ & 53 \\
\hline 68 & $\begin{array}{l}\text { Seba I., Rowley J., } \\
\text { Delbridge R. }\end{array}$ & $\begin{array}{l}\text { Knowledge sharing in the Dubai Police } \\
\text { Force }\end{array}$ & 2012 & $\begin{array}{l}\text { Journal of Knowledge } \\
\text { Management }\end{array}$ & 51 \\
\hline 69 & $\begin{array}{l}\text { Lin H.-E., } \\
\text { McDonough Iii E.F. }\end{array}$ & $\begin{array}{l}\text { Investigating the role of leadership and } \\
\text { organizational culture in fostering } \\
\text { innovation ambidexterity }\end{array}$ & 2011 & $\begin{array}{l}\text { IEEE Transactions on } \\
\text { Engineering } \\
\text { Management }\end{array}$ & 51 \\
\hline 70 & $\begin{array}{l}\text { Linderman K., } \\
\text { Schroeder R.G., } \\
\text { Sanders J. }\end{array}$ & $\begin{array}{l}\text { A Knowledge Framework Underlying } \\
\text { Process Management }\end{array}$ & 2010 & Decision Sciences & 50 \\
\hline 71 & Peterson H.C. & $\begin{array}{l}\text { Transformational supply chains and the } \\
\text { 'wicked problem' of sustainability: } \\
\text { Aligning knowledge, innovation, } \\
\text { entrepreneurship, and leadership }\end{array}$ & 2009 & $\begin{array}{l}\text { Journal on Chain and } \\
\text { Network Science }\end{array}$ & 49 \\
\hline 72 & $\begin{array}{l}\text { Jain V., Wadhwa } \\
\text { S., Deshmukh S.G. }\end{array}$ & $\begin{array}{l}\text { Supplier selection using fuzzy association } \\
\text { rules mining approach }\end{array}$ & 2007 & $\begin{array}{l}\text { International Journal of } \\
\text { Production Research }\end{array}$ & 49 \\
\hline 73 & $\begin{array}{l}\text { Ma Z., Qi L., Wang } \\
\text { K. }\end{array}$ & $\begin{array}{l}\text { Knowledge sharing in Chinese } \\
\text { construction project teams and its } \\
\text { affecting factors: An empirical study }\end{array}$ & 2008 & $\begin{array}{l}\text { Chinese Management } \\
\text { Studies }\end{array}$ & 48 \\
\hline 74 & $\begin{array}{l}\text { Hsu S.-H., Shen H.- } \\
\text { P. }\end{array}$ & $\begin{array}{l}\text { Knowledge management and its } \\
\text { relationship with TQM }\end{array}$ & 2005 & $\begin{array}{l}\text { Total Quality } \\
\text { Management and } \\
\text { Business Excellence }\end{array}$ & 47 \\
\hline 75 & $\begin{array}{l}\text { Yang L.-R., Huang } \\
\text { C.-F., Hsu T.-J. }\end{array}$ & $\begin{array}{l}\text { Knowledge leadership to improve project } \\
\text { and organizational performance }\end{array}$ & 2014 & $\begin{array}{l}\text { International Journal of } \\
\text { Project Management }\end{array}$ & 46 \\
\hline 76 & $\begin{array}{l}\text { Grimaldi M., } \\
\text { Cricelli L., Rogo F. }\end{array}$ & $\begin{array}{l}\text { A methodology to assess value creation in } \\
\text { communities of innovation }\end{array}$ & 2012 & $\begin{array}{l}\text { Journal of Intellectual } \\
\text { Capital }\end{array}$ & 46 \\
\hline 77 & $\begin{array}{l}\text { Tchokogué A., } \\
\text { Bareil C., Duguay } \\
\text { C.R. }\end{array}$ & $\begin{array}{l}\text { Key lessons from the implementation of } \\
\text { an ERP at Pratt \& Whitney Canada }\end{array}$ & 2005 & $\begin{array}{l}\text { International Journal of } \\
\text { Production Economics }\end{array}$ & 46 \\
\hline
\end{tabular}




\begin{tabular}{|c|c|c|c|c|c|}
\hline 78 & Handzic M. & $\begin{array}{l}\text { Integrated socio-technical knowledge } \\
\text { management model: An empirical } \\
\text { evaluation }\end{array}$ & 2011 & $\begin{array}{l}\text { Journal of Knowledge } \\
\text { Management }\end{array}$ & 45 \\
\hline 79 & $\begin{array}{l}\text { Cater III J.J., Justis } \\
\text { R.T. }\end{array}$ & $\begin{array}{l}\text { The Development of Successors From } \\
\text { Followers to Leaders in Small Family } \\
\text { Firms: An Exploratory Study }\end{array}$ & 2009 & Family Business Review & 45 \\
\hline 80 & Lakshman C. & $\begin{array}{l}\text { Organizational knowledge leadership: A } \\
\text { grounded theory approach }\end{array}$ & 2007 & $\begin{array}{l}\text { Leadership and } \\
\text { Organization } \\
\text { Development Journal }\end{array}$ & 45 \\
\hline 81 & Sun P. & $\begin{array}{l}\text { Five critical knowledge management } \\
\text { organizational themes }\end{array}$ & 2010 & $\begin{array}{l}\text { Journal of Knowledge } \\
\text { Management }\end{array}$ & 44 \\
\hline 82 & $\begin{array}{l}\text { Gratton L., Voigt } \\
\text { A., Erickson T. }\end{array}$ & Bridging faultlines in diverse teams & 2007 & $\begin{array}{l}\text { MIT Sloan Management } \\
\text { Review }\end{array}$ & 44 \\
\hline 83 & Kodama M. & $\begin{array}{l}\text { New knowledge creation through } \\
\text { leadership-based strategic community - A } \\
\text { case of new product development in IT } \\
\text { and multimedia business fields }\end{array}$ & 2005 & Technovation & 44 \\
\hline 84 & Inkinen $\mathrm{H}$. & $\begin{array}{l}\text { Review of empirical research on } \\
\text { knowledge management practices and firm } \\
\text { performance }\end{array}$ & 2016 & $\begin{array}{l}\text { Journal of Knowledge } \\
\text { Management }\end{array}$ & 43 \\
\hline 85 & Viitala R. & Towards knowledge leadership & 2004 & $\begin{array}{l}\text { Leadership \& } \\
\text { Organization } \\
\text { Development Journal }\end{array}$ & 43 \\
\hline 86 & Jakubik M. & $\begin{array}{l}\text { Exploring the knowledge landscape: Four } \\
\text { emerging views of knowledge }\end{array}$ & 2007 & $\begin{array}{l}\text { Journal of Knowledge } \\
\text { Management }\end{array}$ & 42 \\
\hline 87 & Kodama M. & $\begin{array}{l}\text { Innovation and knowledge creation } \\
\text { through leadership-based strategic } \\
\text { community: Case study on high-tech } \\
\text { company in Japan }\end{array}$ & 2007 & Technovation & 42 \\
\hline 88 & $\begin{array}{l}\text { Søndergaard S., } \\
\text { Kerr M., Clegg C. }\end{array}$ & $\begin{array}{l}\text { Sharing knowledge: Contextualising } \\
\text { socio-technical thinking and practice }\end{array}$ & 2007 & Learning Organization & 40 \\
\hline 89 & $\begin{array}{l}\text { Fedor D.B., Ghosh } \\
\text { S., Caldwell S.D., } \\
\text { Maurer T.J., } \\
\text { Singhal V.R. }\end{array}$ & $\begin{array}{l}\text { The Effects of Knowledge Management } \\
\text { on Team Members' Ratings of Project } \\
\text { Success and Impact }\end{array}$ & 2003 & Decision Sciences & 40 \\
\hline 90 & $\begin{array}{l}\text { Pinho I., Rego A., } \\
\text { Cunha M.P. }\end{array}$ & $\begin{array}{l}\text { Improving knowledge management } \\
\text { processes: A hybrid positive approach }\end{array}$ & 2012 & $\begin{array}{l}\text { Journal of Knowledge } \\
\text { Management }\end{array}$ & 39 \\
\hline 91 & $\begin{array}{l}\text { Lord R.G., } \\
\text { Shondrick S.J. }\end{array}$ & $\begin{array}{l}\text { Leadership and knowledge: Symbolic, } \\
\text { connectionist, and embodied perspectives }\end{array}$ & 2011 & Leadership Quarterly & 39 \\
\hline 92 & Edge K. & $\begin{array}{l}\text { Powerful public sector knowledge } \\
\text { management: A school district example }\end{array}$ & 2005 & $\begin{array}{l}\text { Journal of Knowledge } \\
\text { Management }\end{array}$ & 39 \\
\hline 93 & Osarenkhoe A. & $\begin{array}{l}\text { A study of inter-firm dynamics between } \\
\text { competition and cooperation - A } \\
\text { coopetition strategy }\end{array}$ & 2010 & $\begin{array}{l}\text { Journal of Database } \\
\text { Marketing and } \\
\text { Customer Strategy } \\
\text { Management } \\
\end{array}$ & 38 \\
\hline 94 & $\begin{array}{l}\text { Dasgupta M., Gupta } \\
\text { R.K. }\end{array}$ & $\begin{array}{l}\text { Innovation in organizations: A review of } \\
\text { the role of organizational learning and } \\
\text { knowledge management }\end{array}$ & 2009 & Global Business Review & 38 \\
\hline 95 & $\begin{array}{l}\text { Parolia N., } \\
\text { Goodman S., Li Y., } \\
\text { Jiang J.J. }\end{array}$ & $\begin{array}{l}\text { Mediators between coordination and IS } \\
\text { project performance }\end{array}$ & 2007 & $\begin{array}{l}\text { Information and } \\
\text { Management }\end{array}$ & 38 \\
\hline 96 & $\begin{array}{l}\text { Gottschalk P., Terje } \\
\text { Karlsen J. }\end{array}$ & $\begin{array}{l}\text { A comparison of leadership roles in } \\
\text { internal IT projects versus outsourcing } \\
\text { projects }\end{array}$ & 2005 & $\begin{array}{l}\text { Industrial Management } \\
\& \text { Data Systems }\end{array}$ & 38 \\
\hline 97 & $\begin{array}{l}\text { Masa'deh R., } \\
\text { Obeidat B.Y., } \\
\text { Tarhini A. }\end{array}$ & $\begin{array}{l}\text { A Jordanian empirical study of the } \\
\text { associations among transformational } \\
\text { leadership, transactional leadership, } \\
\text { knowledge sharing, job performance, and } \\
\text { firm performance: A structural equation } \\
\text { modelling approach }\end{array}$ & 2016 & $\begin{array}{l}\text { Journal of Management } \\
\text { Development }\end{array}$ & 37 \\
\hline
\end{tabular}




\begin{tabular}{|c|c|c|c|c|c|}
\hline 98 & Wu J., Chen X. & $\begin{array}{l}\text { Leaders' social ties, knowledge acquisition } \\
\text { capability and firm competitive advantage }\end{array}$ & 2012 & $\begin{array}{l}\text { Asia Pacific Journal of } \\
\text { Management }\end{array}$ & 37 \\
\hline 99 & $\begin{array}{l}\text { Magnier-Watanabe } \\
\text { R., Benton C., } \\
\text { Senoo D. }\end{array}$ & $\begin{array}{l}\text { A study of knowledge management } \\
\text { enablers across countries }\end{array}$ & 2011 & $\begin{array}{l}\text { Knowledge } \\
\text { Management Research } \\
\text { and Practice }\end{array}$ & 37 \\
\hline 100 & $\begin{array}{l}\text { Leach L.S., Myrtle } \\
\text { R.C., Weaver F.A., } \\
\text { Dasu S. }\end{array}$ & $\begin{array}{l}\text { Assessing the performance of surgical } \\
\text { teams }\end{array}$ & 2009 & $\begin{array}{l}\text { Health Care } \\
\text { Management Review }\end{array}$ & 37 \\
\hline 101 & $\begin{array}{l}\text { Li G., Shang Y., } \\
\text { Liu H., Xi Y. }\end{array}$ & $\begin{array}{l}\text { Differentiated transformational leadership } \\
\text { and knowledge sharing: A cross-level } \\
\text { investigation }\end{array}$ & 2014 & $\begin{array}{l}\text { European Management } \\
\text { Journal }\end{array}$ & 36 \\
\hline 102 & $\begin{array}{l}\text { Menguc B., Auh S., } \\
\text { Uslu A. }\end{array}$ & $\begin{array}{l}\text { Customer knowledge creation capability } \\
\text { and performance in sales teams }\end{array}$ & 2013 & $\begin{array}{l}\text { Journal of the Academy } \\
\text { of Marketing Science }\end{array}$ & 36 \\
\hline 103 & Lewis D. & $\begin{array}{l}\text { Five years on - the organizational culture } \\
\text { saga revisited }\end{array}$ & 2002 & $\begin{array}{l}\text { Leadership \& } \\
\text { Organization } \\
\text { Development Journal }\end{array}$ & 35 \\
\hline 104 & $\begin{array}{l}\text { Farris G.F., } \\
\text { Cordero R. }\end{array}$ & $\begin{array}{l}\text { Leading your scientists and engineers } \\
2002\end{array}$ & 2002 & $\begin{array}{l}\text { Research Technology } \\
\text { Management }\end{array}$ & 35 \\
\hline 105 & $\begin{array}{l}\text { Faraj S., } \\
\text { Kudaravalli S., } \\
\text { Wasko M. }\end{array}$ & $\begin{array}{l}\text { Leading collaboration in online } \\
\text { communities }\end{array}$ & 2015 & $\begin{array}{l}\text { MIS Quarterly: } \\
\text { Management } \\
\text { Information Systems }\end{array}$ & 34 \\
\hline 106 & $\begin{array}{l}\text { Kim Y.-M., } \\
\text { Newby-Bennett D., } \\
\text { Song H.-J. }\end{array}$ & $\begin{array}{l}\text { Knowledge sharing and institutionalism in } \\
\text { the healthcare industry }\end{array}$ & 2012 & $\begin{array}{l}\text { Journal of Knowledge } \\
\text { Management }\end{array}$ & 34 \\
\hline 107 & Lakshman C. & $\begin{array}{l}\text { Postacquisition cultural integration in } \\
\text { mergers \& acquisitions: A knowledge- } \\
\text { based approach }\end{array}$ & 2011 & $\begin{array}{l}\text { Human Resource } \\
\text { Management }\end{array}$ & 34 \\
\hline 108 & Chawla D., Joshi H. & $\begin{array}{l}\text { Knowledge management initiatives in } \\
\text { Indian public and private sector } \\
\text { organizations }\end{array}$ & 2010 & $\begin{array}{l}\text { Journal of Knowledge } \\
\text { Management }\end{array}$ & 34 \\
\hline 109 & $\begin{array}{l}\text { Simonin B.L., } \\
\text { Özsomer A. }\end{array}$ & $\begin{array}{l}\text { Knowledge processes and learning } \\
\text { outcomes in MNCS: An empirical } \\
\text { investigation of the role of HRM practices } \\
\text { in foreign subsidiaries }\end{array}$ & 2009 & $\begin{array}{l}\text { Human Resource } \\
\text { Management }\end{array}$ & 34 \\
\hline 110 & Lakshman C. & $\begin{array}{l}\text { Organizational knowledge leadership: An } \\
\text { empirical examination of knowledge } \\
\text { management by top executive leaders }\end{array}$ & 2009 & $\begin{array}{l}\text { Leadership and } \\
\text { Organization } \\
\text { Development Journal }\end{array}$ & 34 \\
\hline 111 & $\begin{array}{l}\text { Lee A.H.I., Chen } \\
\text { H.H., Tong Y. }\end{array}$ & $\begin{array}{l}\text { Developing new products in a network } \\
\text { with efficiency and innovation }\end{array}$ & 2008 & $\begin{array}{l}\text { International Journal of } \\
\text { Production Research }\end{array}$ & 32 \\
\hline 112 & Smith P.A.C. & $\begin{array}{l}\text { Knowledge sharing and strategic capital. } \\
\text { The importance and identification of } \\
\text { opinion leaders: The importance and } \\
\text { identification of opinion leaders }\end{array}$ & 2005 & Learning Organization & 32 \\
\hline 113 & $\begin{array}{l}\text { Ingelgård A., Roth } \\
\text { J., Styhre A., Shani } \\
\text { A.B.R. }\end{array}$ & $\begin{array}{l}\text { Dynamic learning capability and } \\
\text { actionable knowledge creation: Clinical } \\
\text { R\&D in a pharmaceutical company }\end{array}$ & 2002 & $\begin{array}{l}\text { The Learning } \\
\text { Organization }\end{array}$ & 32 \\
\hline 114 & $\begin{array}{l}\text { Berglund } \mathrm{H} ., \\
\text { Sandström C. }\end{array}$ & $\begin{array}{l}\text { Business model innovation from an open } \\
\text { systems perspective: Structural challenges } \\
\text { and managerial solutions }\end{array}$ & 2013 & $\begin{array}{l}\text { International Journal of } \\
\text { Product Development }\end{array}$ & 31 \\
\hline 115 & $\begin{array}{l}\text { Sutanto J., Tan C.- } \\
\text { H., Battistini B., } \\
\text { Phang C.W. }\end{array}$ & $\begin{array}{l}\text { Emergent leadership in virtual } \\
\text { collaboration settings: A social network } \\
\text { analysis approach }\end{array}$ & 2011 & Long Range Planning & 31 \\
\hline 116 & $\begin{array}{l}\text { Teerajetgul W., } \\
\text { Charoenngam C. }\end{array}$ & $\begin{array}{l}\text { Factors inducing knowledge creation: } \\
\text { Empirical evidence from Thai construction } \\
\text { projects }\end{array}$ & 2006 & $\begin{array}{l}\text { Engineering, } \\
\text { Construction and } \\
\text { Architectural } \\
\text { Management } \\
\end{array}$ & 31 \\
\hline 117 & Retna K.S., Ng P.T. & $\begin{array}{l}\text { Communities of practice: Dynamics and } \\
\text { success factors }\end{array}$ & 2011 & $\begin{array}{l}\text { Leadership and } \\
\text { Organization } \\
\text { Development Journal }\end{array}$ & 30 \\
\hline 118 & Frost D. & 'Teacher leadership': Values and voice & 2008 & $\begin{array}{l}\text { School Leadership and } \\
\text { Management }\end{array}$ & 30 \\
\hline
\end{tabular}




\begin{tabular}{|c|c|c|c|c|c|}
\hline 119 & Söderlund J. & $\begin{array}{l}\text { Competence dynamics and learning } \\
\text { processes in project-based firms: Shifting, } \\
\text { adapting and leveraging }\end{array}$ & 2008 & $\begin{array}{l}\text { International Journal of } \\
\text { Innovation Management }\end{array}$ & 29 \\
\hline 120 & $\begin{array}{l}\text { Pham N.T., } \\
\text { Swierczek F.W. }\end{array}$ & $\begin{array}{l}\text { Facilitators of organizational learning in } \\
\text { design }\end{array}$ & 2006 & Learning Organization & 29 \\
\hline 121 & Kodama M. & $\begin{array}{l}\text { Customer value creation through } \\
\text { knowledge creation with customers: Case } \\
\text { studies of IT and multimedia businesses in } \\
\text { Japan }\end{array}$ & 2005 & $\begin{array}{l}\text { International Journal of } \\
\text { Innovation and } \\
\text { Learning }\end{array}$ & 29 \\
\hline 122 & $\begin{array}{l}\text { Chang J., Bai X., Li } \\
\text { J.J. }\end{array}$ & $\begin{array}{l}\text { The influence of leadership on product and } \\
\text { process innovations in China: The } \\
\text { contingent role of knowledge acquisition } \\
\text { capability }\end{array}$ & 2015 & $\begin{array}{l}\text { Industrial Marketing } \\
\text { Management }\end{array}$ & 28 \\
\hline 123 & $\begin{array}{l}\text { Kidd J., Li X., } \\
\text { Richter F.-J. }\end{array}$ & $\begin{array}{l}\text { Learning and trust in supply chain } \\
\text { management }\end{array}$ & 2003 & Management Decision & 28 \\
\hline 124 & Ward A. & $\begin{array}{l}\text { Getting strategic value from constellations } \\
\text { of communities }\end{array}$ & 2000 & Strategy \& Leadership & 28 \\
\hline 125 & $\begin{array}{l}\text { Liu Y., DeFrank } \\
\text { R.S. }\end{array}$ & $\begin{array}{l}\text { Self-interest and knowledge-sharing } \\
\text { intentions: The impacts of } \\
\text { transformational leadership climate and } \\
\text { HR practices }\end{array}$ & 2013 & $\begin{array}{l}\text { International Journal of } \\
\text { Human Resource } \\
\text { Management }\end{array}$ & 27 \\
\hline 126 & $\begin{array}{l}\text { Teerajetgul W., } \\
\text { Chareonngam C., } \\
\text { Wethyavivorn P. }\end{array}$ & $\begin{array}{l}\text { Key knowledge factors in Thai } \\
\text { construction practice }\end{array}$ & 2009 & $\begin{array}{l}\text { International Journal of } \\
\text { Project Management }\end{array}$ & 27 \\
\hline 127 & $\begin{array}{l}\text { Gowen III C.R., } \\
\text { Henagan S.C., } \\
\text { McFadden K.L. }\end{array}$ & $\begin{array}{l}\text { Knowledge management as a mediator for } \\
\text { the efficacy of transformational leadership } \\
\text { and quality management initiatives in U.S. } \\
\text { health care }\end{array}$ & 2009 & $\begin{array}{l}\text { Health Care } \\
\text { Management Review }\end{array}$ & 27 \\
\hline 128 & $\begin{array}{l}\text { Martin J.S., Marion } \\
\text { R. }\end{array}$ & $\begin{array}{l}\text { Higher education leadership roles in } \\
\text { knowledge processing }\end{array}$ & 2005 & Learning Organization & 27 \\
\hline 129 & $\begin{array}{l}\text { Wei Choo C., } \\
\text { Johnston R. }\end{array}$ & $\begin{array}{l}\text { Innovation in the knowing organization: A } \\
\text { case study of an e-commerce initiative }\end{array}$ & 2004 & $\begin{array}{l}\text { Journal of Knowledge } \\
\text { Management }\end{array}$ & 27 \\
\hline 130 & Reinmoeller P. & $\begin{array}{l}\text { The knowledge-based view of the firm and } \\
\text { upper echelon theory: exploring the } \\
\text { agency of TMT }\end{array}$ & 2004 & $\begin{array}{l}\text { International Journal of } \\
\text { Learning and } \\
\text { Intellectual Capital }\end{array}$ & 27 \\
\hline 131 & Iles P., Yolles M. & $\begin{array}{l}\text { Across the great divide: } \mathrm{HRD} \text {, technology } \\
\text { translation, and knowledge migration in } \\
\text { bridging the knowledge gap between } \\
\text { SMEs and Universities }\end{array}$ & 2002 & $\begin{array}{l}\text { Human Resource } \\
\text { Development } \\
\text { International }\end{array}$ & 27 \\
\hline 132 & $\begin{array}{l}\text { Han S.H., Seo G., } \\
\text { Yoon S.W., Yoon } \\
\text { D.-Y. }\end{array}$ & $\begin{array}{l}\text { Transformational leadership and } \\
\text { knowledge sharing: Mediating roles of } \\
\text { employee's empowerment, commitment, } \\
\text { and citizenship behaviors }\end{array}$ & 2016 & $\begin{array}{l}\text { Journal of Workplace } \\
\text { Learning }\end{array}$ & 26 \\
\hline 133 & $\begin{array}{l}\text { Valmohammadi C., } \\
\text { Ahmadi M. }\end{array}$ & $\begin{array}{l}\text { The impact of knowledge management } \\
\text { practices on organizational performance: } \\
\text { A balanced scorecard approach }\end{array}$ & 2015 & $\begin{array}{l}\text { Journal of Enterprise } \\
\text { Information } \\
\text { Management }\end{array}$ & 26 \\
\hline 134 & $\begin{array}{l}\text { Huang Q., Davison } \\
\text { R.M., Liu H., Gu J. }\end{array}$ & $\begin{array}{l}\text { The impact of leadership style on } \\
\text { knowledge-sharing intentions in China }\end{array}$ & 2008 & $\begin{array}{l}\text { Journal of Global } \\
\text { Information } \\
\text { Management }\end{array}$ & 26 \\
\hline 135 & $\begin{array}{l}\text { Cavaliere V., } \\
\text { Lombardi S., } \\
\text { Giustiniano L. }\end{array}$ & $\begin{array}{l}\text { Knowledge sharing in knowledge- } \\
\text { intensive manufacturing firms. An } \\
\text { empirical study of its enablers }\end{array}$ & 2015 & $\begin{array}{l}\text { Journal of Knowledge } \\
\text { Management }\end{array}$ & 25 \\
\hline 136 & $\begin{array}{l}\text { Loke S.-P., Downe } \\
\text { A.G., Sambasivan } \\
\text { M., Khalid K. }\end{array}$ & $\begin{array}{l}\text { A structural approach to integrating total } \\
\text { quality management and knowledge } \\
\text { management with supply chain learning }\end{array}$ & 2012 & $\begin{array}{l}\text { Journal of Business } \\
\text { Economics and } \\
\text { Management }\end{array}$ & 25 \\
\hline 137 & $\begin{array}{l}\text { Jayasingam S., } \\
\text { Ansari M.A., Jantan } \\
\text { M. }\end{array}$ & $\begin{array}{l}\text { Influencing knowledge workers: The } \\
\text { power of top management }\end{array}$ & 2010 & $\begin{array}{l}\text { Industrial Management } \\
\text { and Data Systems }\end{array}$ & 25 \\
\hline 138 & $\begin{array}{l}\text { Abdul-Rahman H., } \\
\text { Yahya I.A., Berawi } \\
\text { M.A., Wah L.W. }\end{array}$ & $\begin{array}{l}\text { Conceptual delay mitigation model using a } \\
\text { project learning approach in practice }\end{array}$ & 2008 & $\begin{array}{l}\text { Construction } \\
\text { Management and } \\
\text { Economics }\end{array}$ & 25 \\
\hline
\end{tabular}




\begin{tabular}{|c|c|c|c|c|c|}
\hline 139 & Bundred S. & Solutions to silos: Joining up knowledge & 2006 & $\begin{array}{l}\text { Public Money and } \\
\text { Management }\end{array}$ & 25 \\
\hline 140 & $\begin{array}{l}\text { Tung H.L., Chang } \\
\text { Y.H. }\end{array}$ & $\begin{array}{l}\text { Effects of empowering leadership on } \\
\text { performance in management team: } \\
\text { Mediating effects of knowledge sharing } \\
\text { and team cohesion }\end{array}$ & 2011 & $\begin{array}{l}\text { Journal of Chinese } \\
\text { Human Resources } \\
\text { Management }\end{array}$ & 24 \\
\hline 141 & $\begin{array}{l}\text { Lampel J., } \\
\text { Scarbrough H., } \\
\text { Macmillan S. }\end{array}$ & $\begin{array}{l}\text { Managing through Projects in Knowledge- } \\
\text { based Environments. Special Issue } \\
\text { Introduction by the Guest Editors }\end{array}$ & 2008 & Long Range Planning & 24 \\
\hline 142 & $\begin{array}{l}\text { Swift P.E., Hwang } \\
\text { A. }\end{array}$ & $\begin{array}{l}\text { Learning, dynamic capabilities and } \\
\text { operating routines: A consumer package } \\
\text { goods company }\end{array}$ & 2008 & Learning Organization & 24 \\
\hline 143 & Ashworth M.J. & $\begin{array}{l}\text { Preserving knowledge legacies: } \\
\text { Workforce aging, turnover and human } \\
\text { resource issues in the US electric power } \\
\text { industry }\end{array}$ & 2006 & $\begin{array}{l}\text { International Journal of } \\
\text { Human Resource } \\
\text { Management }\end{array}$ & 24 \\
\hline 144 & $\begin{array}{l}\text { Caridi-Zahavi O., } \\
\text { Carmeli A., Arazy } \\
\text { O. }\end{array}$ & $\begin{array}{l}\text { The Influence of CEOs' Visionary } \\
\text { Innovation Leadership on the Performance } \\
\text { of High-Technology Ventures: The } \\
\text { Mediating Roles of Connectivity and } \\
\text { Knowledge Integration }\end{array}$ & 2016 & $\begin{array}{l}\text { Journal of Product } \\
\text { Innovation Management }\end{array}$ & 23 \\
\hline 145 & $\begin{array}{l}\text { Pratoom K., } \\
\text { Savatsomboon G. }\end{array}$ & $\begin{array}{l}\text { Explaining factors affecting individual } \\
\text { innovation: The case of producer group } \\
\text { members in Thailand }\end{array}$ & 2012 & $\begin{array}{l}\text { Asia Pacific Journal of } \\
\text { Management }\end{array}$ & 23 \\
\hline 146 & Chawla D., Joshi H. & $\begin{array}{l}\text { Knowledge management practices in } \\
\text { Indian industries - a comparative study }\end{array}$ & 2010 & $\begin{array}{l}\text { Journal of Knowledge } \\
\text { Management }\end{array}$ & 23 \\
\hline 147 & $\begin{array}{l}\text { Chong C.W., } \\
\text { Chong S.C. }\end{array}$ & $\begin{array}{l}\text { Knowledge management process } \\
\text { effectiveness: Measurement of preliminary } \\
\text { knowledge management implementation }\end{array}$ & 2009 & $\begin{array}{l}\text { Knowledge } \\
\text { Management Research } \\
\text { and Practice }\end{array}$ & 23 \\
\hline 148 & $\begin{array}{l}\text { Bai Y., Lin L., Li } \\
\text { P.P. }\end{array}$ & $\begin{array}{l}\text { How to enable employee creativity in a } \\
\text { team context: A cross-level mediating } \\
\text { process of transformational leadership }\end{array}$ & 2016 & $\begin{array}{l}\text { Journal of Business } \\
\text { Research }\end{array}$ & 22 \\
\hline 149 & $\begin{array}{l}\text { Choi S.B., Kim K., } \\
\text { Ullah S.M.E., Kang } \\
\text { S.-W. }\end{array}$ & $\begin{array}{l}\text { How transformational leadership } \\
\text { facilitates innovative behavior of Korean } \\
\text { workers: Examining mediating and } \\
\text { moderating processes }\end{array}$ & 2016 & Personnel Review & 22 \\
\hline 150 & $\begin{array}{l}\text { Jain A.K., Jeppesen } \\
\text { H.J. }\end{array}$ & $\begin{array}{l}\text { Knowledge management practices in a } \\
\text { public sector organisation: The role of } \\
\text { leaders' cognitive styles }\end{array}$ & 2013 & $\begin{array}{l}\text { Journal of Knowledge } \\
\text { Management }\end{array}$ & 22 \\
\hline 151 & $\begin{array}{l}\text { Mohamed M.S., } \\
\text { O'Sullivan K.J., } \\
\text { Ribière V. }\end{array}$ & $\begin{array}{l}\text { A paradigm shift in the Arab region } \\
\text { knowledge evolution }\end{array}$ & 2008 & $\begin{array}{l}\text { Journal of Knowledge } \\
\text { Management }\end{array}$ & 22 \\
\hline 152 & $\begin{array}{l}\text { Jaana M., Ward } \\
\text { M.M., Paré G., } \\
\text { Sicotte C. }\end{array}$ & $\begin{array}{l}\text { Antecedents of clinical information } \\
\text { technology sophistication in hospitals }\end{array}$ & 2006 & $\begin{array}{l}\text { Health Care } \\
\text { Management Review }\end{array}$ & 22 \\
\hline 153 & $\begin{array}{l}\text { Carson D.A., } \\
\text { Carson D.B., } \\
\text { Hodge H. }\end{array}$ & $\begin{array}{l}\text { Understanding local innovation systems in } \\
\text { peripheral tourism destinations }\end{array}$ & 2014 & Tourism Geographies & 21 \\
\hline 154 & $\begin{array}{l}\text { Hemmasi M., } \\
\text { Csanda C.M. }\end{array}$ & $\begin{array}{l}\text { The effectiveness of communities of } \\
\text { practice: An empirical study }\end{array}$ & 2009 & $\begin{array}{l}\text { Journal of Managerial } \\
\text { Issues }\end{array}$ & 21 \\
\hline 155 & Hemlin S. & $\begin{array}{l}\text { Creative knowledge environments: An } \\
\text { interview study with group members and } \\
\text { group leaders of university and industry } \\
\text { r\&d groups in biotechnology }\end{array}$ & 2009 & $\begin{array}{l}\text { Creativity and } \\
\text { Innovation Management }\end{array}$ & 21 \\
\hline 156 & $\begin{array}{l}\text { McAdam R., Reid } \\
\text { R., Shevlin M. }\end{array}$ & $\begin{array}{l}\text { Determinants for innovation } \\
\text { implementation at SME and inter SME } \\
\text { levels within peripheral regions }\end{array}$ & 2014 & $\begin{array}{l}\text { International Journal of } \\
\text { Entrepreneurial } \\
\text { Behaviour and } \\
\text { Research }\end{array}$ & 20 \\
\hline 157 & $\begin{array}{l}\text { Borzillo S., } \\
\text { Kaminska-Labbé R. }\end{array}$ & $\begin{array}{l}\text { Unravelling the dynamics of knowledge } \\
\text { creation in communities of practice though } \\
\text { complexity theory lenses }\end{array}$ & 2011 & $\begin{array}{l}\text { Knowledge } \\
\text { Management Research } \\
\text { and Practice }\end{array}$ & 20 \\
\hline
\end{tabular}




\begin{tabular}{|c|c|c|c|c|c|}
\hline 158 & $\begin{array}{l}\text { Carmeli A., } \\
\text { Waldman D.A. }\end{array}$ & $\begin{array}{l}\text { Leadership, behavioral context, and the } \\
\text { performance of work groups in a } \\
\text { knowledge-intensive setting }\end{array}$ & 2010 & $\begin{array}{l}\text { Journal of Technology } \\
\text { Transfer }\end{array}$ & 20 \\
\hline 159 & $\begin{array}{l}\text { Ruben B.D., Russ } \\
\text { T., Smulowitz } \\
\text { S.M., Connaughton } \\
\text { S.L. }\end{array}$ & $\begin{array}{l}\text { Evaluating the impact of organizational } \\
\text { self-assessment in higher education: The } \\
\text { Malcolm Baldrige/Excellence in Higher } \\
\text { Education framework }\end{array}$ & 2007 & $\begin{array}{l}\text { Leadership and } \\
\text { Organization } \\
\text { Development Journal }\end{array}$ & 20 \\
\hline 160 & $\begin{array}{l}\text { Pauleen D.J., } \\
\text { Corbitt B., Yoong } \\
\text { P. }\end{array}$ & $\begin{array}{l}\text { Discovering and articulating what is not } \\
\text { yet known: Using action learning and } \\
\text { grounded theory as a knowledge } \\
\text { management strategy }\end{array}$ & 2007 & Learning Organization & 20 \\
\hline 161 & Peet M. & $\begin{array}{l}\text { Leadership transitions, tacit knowledge } \\
\text { sharing and organizational generativity }\end{array}$ & 2012 & $\begin{array}{l}\text { Journal of Knowledge } \\
\text { Management }\end{array}$ & 19 \\
\hline 162 & $\begin{array}{l}\text { Behrend F.D., } \\
\text { Erwee R. }\end{array}$ & $\begin{array}{l}\text { Mapping knowledge flows in virtual teams } \\
\text { with SNA }\end{array}$ & 2009 & $\begin{array}{l}\text { Journal of Knowledge } \\
\text { Management }\end{array}$ & 19 \\
\hline 163 & $\begin{array}{l}\text { Hong H.-K., Kim } \\
\text { J.-S., Kim T., Leem } \\
\text { B.-H. }\end{array}$ & $\begin{array}{l}\text { The effect of knowledge on system } \\
\text { integration project performance }\end{array}$ & 2008 & $\begin{array}{l}\text { Industrial Management } \\
\text { and Data Systems }\end{array}$ & 19 \\
\hline 164 & $\begin{array}{l}\text { Awazu Y., Desouza } \\
\text { K. }\end{array}$ & $\begin{array}{l}\text { The knowledge chiefs: CKOs, CLOs and } \\
\text { CPOs }\end{array}$ & 2004 & $\begin{array}{l}\text { European Management } \\
\text { Journal }\end{array}$ & 19 \\
\hline 165 & $\begin{array}{l}\text { Pemberton J.D., } \\
\text { Stonehouse G.H., } \\
\text { Francis M.S. }\end{array}$ & $\begin{array}{l}\text { Black and Decker-towards a knowledge- } \\
\text { centric organization }\end{array}$ & 2002 & $\begin{array}{l}\text { Knowledge and Process } \\
\text { Management }\end{array}$ & 19 \\
\hline 166 & Chatzkel J. & A conversation with Hubert Saint-Onge & 2000 & $\begin{array}{l}\text { Journal of Intellectual } \\
\text { Capital }\end{array}$ & 19 \\
\hline 167 & $\begin{array}{l}\text { Lee A., Willis S., } \\
\text { Tian A.W. }\end{array}$ & $\begin{array}{l}\text { Empowering leadership: A meta-analytic } \\
\text { examination of incremental contribution, } \\
\text { mediation, and moderation }\end{array}$ & 2018 & $\begin{array}{l}\text { Journal of } \\
\text { Organizational } \\
\text { Behavior }\end{array}$ & 18 \\
\hline 168 & Zieba M., Zieba K. & $\begin{array}{l}\text { Knowledge management critical success } \\
\text { factors and the innovativeness of KIBS } \\
\text { companies }\end{array}$ & 2014 & Engineering Economics & 18 \\
\hline 169 & $\begin{array}{l}\text { Zyngier S., Burstein } \\
\text { F. }\end{array}$ & $\begin{array}{l}\text { Knowledge management governance: The } \\
\text { road to continuous benefits realization }\end{array}$ & 2012 & $\begin{array}{l}\text { Journal of Information } \\
\text { Technology }\end{array}$ & 18 \\
\hline 170 & $\begin{array}{l}\text { Li H.C., Mirmirani } \\
\text { S., Ilacqua J.A. }\end{array}$ & $\begin{array}{l}\text { Confucius Institutes distributed leadership } \\
\text { and knowledge sharing in a worldwide } \\
\text { network }\end{array}$ & 2009 & Learning Organization & 18 \\
\hline 171 & $\begin{array}{l}\text { Sarker S., Sarker S., } \\
\text { Schneider C. }\end{array}$ & $\begin{array}{l}\text { Seeing remote team members as leaders: } \\
\text { A study of US-Scandinavian teams }\end{array}$ & 2009 & $\begin{array}{l}\text { IEEE Transactions on } \\
\text { Professional } \\
\text { Communication }\end{array}$ & 18 \\
\hline 172 & $\begin{array}{l}\text { Kant R., Singh } \\
\text { M.D. }\end{array}$ & $\begin{array}{l}\text { Knowledge management implementation: } \\
\text { Modelling the variables }\end{array}$ & 2009 & $\begin{array}{l}\text { International Journal of } \\
\text { Innovation and } \\
\text { Learning }\end{array}$ & 18 \\
\hline 173 & Miles R.E. & Innovation and leadership values & 2007 & $\begin{array}{l}\text { California Management } \\
\text { Review }\end{array}$ & 18 \\
\hline 174 & $\begin{array}{l}\text { Allen T.J., Gloor } \\
\text { P.A., Fronzetti } \\
\text { Colladon A., } \\
\text { Woerner S.L., Raz } \\
\text { O. }\end{array}$ & $\begin{array}{l}\text { The power of reciprocal knowledge } \\
\text { sharing relationships for startup success }\end{array}$ & 2016 & $\begin{array}{l}\text { Journal of Small } \\
\text { Business and Enterprise } \\
\text { Development }\end{array}$ & 17 \\
\hline 175 & $\begin{array}{l}\text { Analoui B.D., } \\
\text { Hannah Doloriert } \\
\text { C., Sambrook S. }\end{array}$ & $\begin{array}{l}\text { Leadership and knowledge management in } \\
\text { UK ICT organisations }\end{array}$ & 2012 & $\begin{array}{l}\text { Journal of Management } \\
\text { Development }\end{array}$ & 17 \\
\hline 176 & $\begin{array}{l}\text { Burstein F., Sohal } \\
\text { S., Zyngier S., } \\
\text { Sohal A.S. } \\
\end{array}$ & $\begin{array}{l}\text { Understanding of knowledge management } \\
\text { roles and responsibilities: A study in the } \\
\text { Australian context }\end{array}$ & 2010 & $\begin{array}{l}\text { Knowledge } \\
\text { Management Research } \\
\text { and Practice }\end{array}$ & 17 \\
\hline 177 & $\begin{array}{l}\text { Chan E.W.L., } \\
\text { Walker D.H.T., } \\
\text { Mills A. }\end{array}$ & $\begin{array}{l}\text { Using a KM framework to evaluate an } \\
\text { ERP system implementation }\end{array}$ & 2009 & $\begin{array}{l}\text { Journal of Knowledge } \\
\text { Management }\end{array}$ & 17 \\
\hline 178 & Sarabia M. & $\begin{array}{l}\text { Knowledge leadership cycles: An } \\
\text { approach from Nonaka's viewpoint }\end{array}$ & 2007 & $\begin{array}{l}\text { Journal of Knowledge } \\
\text { Management }\end{array}$ & 17 \\
\hline
\end{tabular}




\begin{tabular}{|c|c|c|c|c|c|}
\hline 179 & Wing L.S. & $\begin{array}{l}\text { Leadership in high-performance teams: A } \\
\text { model for superior team performance }\end{array}$ & 2005 & $\begin{array}{l}\text { Team Performance } \\
\text { Management: An } \\
\text { International Journal }\end{array}$ & 17 \\
\hline 180 & $\begin{array}{l}\text { Bidmeshgipour M., } \\
\text { Ismail W.K.W., } \\
\text { Omar R. }\end{array}$ & $\begin{array}{l}\text { Knowledge management and } \\
\text { organizational innovativeness in Iranian } \\
\text { banking industry }\end{array}$ & 2012 & $\begin{array}{l}\text { Knowledge } \\
\text { Management and E- } \\
\text { Learning }\end{array}$ & 16 \\
\hline 181 & $\begin{array}{l}\text { Kanchana R., Law } \\
\text { K.M.Y., Comepa } \\
\text { N., Malithong P., } \\
\text { Phusavat K. }\end{array}$ & $\begin{array}{l}\text { Interrelationships among knowledge } \\
\text { management, organisational learning and } \\
\text { innovation }\end{array}$ & 2011 & $\begin{array}{l}\text { International Journal of } \\
\text { Innovation and } \\
\text { Learning }\end{array}$ & 16 \\
\hline 182 & $\begin{array}{l}\text { Pauleen D.J., } \\
\text { Rooney D., Holden } \\
\text { N.J. }\end{array}$ & $\begin{array}{l}\text { Practical wisdom and the development of } \\
\text { cross-cultural knowledge management: A } \\
\text { global leadership perspective }\end{array}$ & 2010 & $\begin{array}{l}\text { European Journal of } \\
\text { International } \\
\text { Management }\end{array}$ & 16 \\
\hline 183 & $\begin{array}{l}\text { Tse H.H.M., } \\
\text { Mitchell R.J. }\end{array}$ & $\begin{array}{l}\text { A theoretical model of transformational } \\
\text { leadership and knowledge creation: The } \\
\text { role of open-mindedness norms and } \\
\text { leader-member exchange }\end{array}$ & 2010 & $\begin{array}{l}\text { Journal of Management } \\
\text { and Organization }\end{array}$ & 16 \\
\hline 184 & $\begin{array}{l}\text { Zulauf Sharicz } \\
\text { C.A., Van } \\
\text { Winkelen C. }\end{array}$ & $\begin{array}{l}\text { Deriving value from inter organizational } \\
\text { learning collaborations }\end{array}$ & 2010 & $\begin{array}{l}\text { The Learning } \\
\text { Organization }\end{array}$ & 16 \\
\hline 185 & $\begin{array}{l}\text { Lee C.-L., Ho C.- } \\
\text { T., Chiu Y.-L. }\end{array}$ & $\begin{array}{l}\text { The impact of knowledge management } \\
\text { enablers on non-financial performance in } \\
\text { small and medium enterprises }\end{array}$ & 2008 & $\begin{array}{l}\text { International Journal of } \\
\text { Technology } \\
\text { Management }\end{array}$ & 16 \\
\hline 186 & Powell J. & $\begin{array}{l}\text { Creative Universities and Their Creative } \\
\text { City-Regions }\end{array}$ & 2007 & $\begin{array}{l}\text { Industry and Higher } \\
\text { Education }\end{array}$ & 16 \\
\hline 187 & $\begin{array}{l}\text { Zárraga-Oberty C., } \\
\text { De Saá-Pérez P. }\end{array}$ & $\begin{array}{l}\text { Work teams to favor knowledge } \\
\text { management: Towards communities of } \\
\text { practice }\end{array}$ & 2006 & $\begin{array}{l}\text { European Business } \\
\text { Review }\end{array}$ & 16 \\
\hline 188 & Kodama M. & $\begin{array}{l}\text { Strategic community-based theory of } \\
\text { firms: Case study of dialectical } \\
\text { management at NTT DoCoMo }\end{array}$ & 2004 & $\begin{array}{l}\text { Systems Research and } \\
\text { Behavioral Science }\end{array}$ & 16 \\
\hline 189 & $\begin{array}{l}\text { Wu W.-L., Lee Y.- } \\
\text { C. }\end{array}$ & $\begin{array}{l}\text { Empowering group leaders encourages } \\
\text { knowledge sharing: integrating the social } \\
\text { exchange theory and positive } \\
\text { organizational behavior perspective }\end{array}$ & 2017 & $\begin{array}{l}\text { Journal of Knowledge } \\
\text { Management }\end{array}$ & 15 \\
\hline 190 & $\begin{array}{l}\text { Edú-Valsania S., } \\
\text { Moriano J.A., } \\
\text { Molero F. }\end{array}$ & $\begin{array}{l}\text { Authentic leadership and employee } \\
\text { knowledge sharing behavior: Mediation of } \\
\text { the innovation climate and workgroup } \\
\text { identification }\end{array}$ & 2016 & $\begin{array}{l}\text { Leadership and } \\
\text { Organization } \\
\text { Development Journal }\end{array}$ & 15 \\
\hline 191 & $\begin{array}{l}\text { Rodriguez A., } \\
\text { Rodriguez Y. }\end{array}$ & $\begin{array}{l}\text { Metaphors for today's leadership: VUCA } \\
\text { world, millennial and "Cloud Leaders" }\end{array}$ & 2015 & $\begin{array}{l}\text { Journal of Management } \\
\text { Development }\end{array}$ & 15 \\
\hline 192 & Zhang L., Cheng J. & $\begin{array}{l}\text { Effect of knowledge leadership on } \\
\text { knowledge sharing in engineering project } \\
\text { design teams: The role of social capital }\end{array}$ & 2015 & $\begin{array}{l}\text { Project Management } \\
\text { Journal }\end{array}$ & 15 \\
\hline 193 & Godfrey D. & $\begin{array}{l}\text { Leadership of schools as research-led } \\
\text { organisations in the English educational } \\
\text { environment: Cultivating a research- } \\
\text { engaged school culture }\end{array}$ & 2013 & $\begin{array}{l}\text { Educational } \\
\text { Management } \\
\text { Administration and } \\
\text { Leadership }\end{array}$ & 15 \\
\hline 194 & $\begin{array}{l}\text { Hajro A., Pudelko } \\
\text { M. }\end{array}$ & $\begin{array}{l}\text { An analysis of core-competences of } \\
\text { successful multinational team leaders }\end{array}$ & 2010 & $\begin{array}{l}\text { International Journal of } \\
\text { Cross Cultural } \\
\text { Management }\end{array}$ & 15 \\
\hline 195 & $\begin{array}{l}\text { Mayfield J., } \\
\text { Mayfield M. }\end{array}$ & $\begin{array}{l}\text { The creative environment's influence on } \\
\text { intent to turnover: A structural equation } \\
\text { model and analysis }\end{array}$ & 2008 & $\begin{array}{l}\text { Management Research } \\
\text { News }\end{array}$ & 15 \\
\hline 196 & $\begin{array}{l}\text { Janson A., } \\
\text { McQueen R.J. }\end{array}$ & $\begin{array}{l}\text { Capturing leadership tacit knowledge in } \\
\text { conversations with leaders }\end{array}$ & 2007 & $\begin{array}{l}\text { Leadership and } \\
\text { Organization } \\
\text { Development Journal }\end{array}$ & 15 \\
\hline 197 & $\begin{array}{l}\text { Gadman S., Cooper } \\
\text { C. }\end{array}$ & $\begin{array}{l}\text { Strategies for collaborating in an } \\
\text { interdependent impermanent world }\end{array}$ & 2005 & $\begin{array}{l}\text { Leadership and } \\
\text { Organization } \\
\text { Development Journal }\end{array}$ & 15 \\
\hline
\end{tabular}




\begin{tabular}{|c|c|c|c|c|c|}
\hline 198 & $\begin{array}{l}\text { Shaw G.L., Harrald } \\
\text { J.R. }\end{array}$ & $\begin{array}{l}\text { Identification of the core competencies } \\
\text { required of executive level business crisis } \\
\text { and continuity managers }\end{array}$ & 2004 & $\begin{array}{l}\text { Journal of Homeland } \\
\text { Security and Emergency } \\
\text { Management }\end{array}$ & 15 \\
\hline 199 & $\begin{array}{l}\text { Imran M.K., Ilyas } \\
\text { M., Aslam U., } \\
\text { Ubaid-Ur-Rahman }\end{array}$ & $\begin{array}{l}\text { Organizational learning through } \\
\text { transformational leadership }\end{array}$ & 2016 & Learning Organization & 14 \\
\hline 200 & $\begin{array}{l}\text { Rawung F.H., } \\
\text { Wuryaningrat N.F., } \\
\text { Elvinit L.E. }\end{array}$ & $\begin{array}{l}\text { The influence of transformational and } \\
\text { transactional leadership on knowledge } \\
\text { sharing: An empirical study on small and } \\
\text { medium businesses in Indonesia }\end{array}$ & 2015 & $\begin{array}{l}\text { Asian Academy of } \\
\text { Management Journal }\end{array}$ & 14 \\
\hline 201 & Kodama M. & $\begin{array}{l}\text { Transforming an old economy company } \\
\text { into a new economy success: the case of } \\
\text { NTT DoCoMo }\end{array}$ & 2002 & $\begin{array}{l}\text { Leadership \& } \\
\text { Organization } \\
\text { Development Journal }\end{array}$ & 14 \\
\hline 202 & $\begin{array}{l}\text { Koohang A., } \\
\text { Paliszkiewicz J., } \\
\text { Goluchowski J. }\end{array}$ & $\begin{array}{l}\text { The impact of leadership on trust, } \\
\text { knowledge management, and } \\
\text { organizational performance: A research } \\
\text { model }\end{array}$ & 2017 & $\begin{array}{l}\text { Industrial Management } \\
\text { and Data Systems }\end{array}$ & 13 \\
\hline 203 & $\begin{array}{l}\text { Hsu C.-C., Tan } \\
\text { K.C., Jayaram J., } \\
\text { Laosirihongthong } \\
\text { T. }\end{array}$ & $\begin{array}{l}\text { Corporate entrepreneurship, operations } \\
\text { core competency and innovation in } \\
\text { emerging economies }\end{array}$ & 2014 & $\begin{array}{l}\text { International Journal of } \\
\text { Production Research }\end{array}$ & 13 \\
\hline 204 & $\begin{array}{l}\text { McCarthy D.J., } \\
\text { Puffer S.M. }\end{array}$ & $\begin{array}{l}\text { Business and management in Russia: A } \\
\text { review of the post-Soviet literature and } \\
\text { future research directions }\end{array}$ & 2013 & $\begin{array}{l}\text { European Journal of } \\
\text { International } \\
\text { Management }\end{array}$ & 13 \\
\hline 205 & Tan C.-Y. & $\begin{array}{l}\text { Instructional leadership: Toward a } \\
\text { contextualised knowledge creation model }\end{array}$ & 2012 & $\begin{array}{l}\text { School Leadership and } \\
\text { Management }\end{array}$ & 13 \\
\hline 206 & Gehani R.R. & $\begin{array}{l}\text { Chester Barnard's "executive" and the } \\
\text { knowledge based firm }\end{array}$ & 2002 & Management Decision & 13 \\
\hline 207 & Edgeman R.L. & $\begin{array}{l}\text { Principle-centered leadership and core } \\
\text { value deployment }\end{array}$ & 1998 & TQM Magazine & 13 \\
\hline 208 & Trong Tuan L. & $\begin{array}{l}\text { Knowledge Sharing in Public } \\
\text { Organizations: The Roles of Servant } \\
\text { Leadership and Organizational Citizenship } \\
\text { Behavior }\end{array}$ & 2017 & $\begin{array}{l}\text { International Journal of } \\
\text { Public Administration }\end{array}$ & 12 \\
\hline 209 & $\begin{array}{l}\text { Corfield A., Paton } \\
\text { R. }\end{array}$ & $\begin{array}{l}\text { Investigating knowledge management: can } \\
\text { KM really change organisational culture? }\end{array}$ & 2016 & $\begin{array}{l}\text { Journal of Knowledge } \\
\text { Management }\end{array}$ & 12 \\
\hline 210 & Merat A., bo D. & $\begin{array}{l}\text { Strategic analysis of knowledge firms: The } \\
\text { links between knowledge management and } \\
\text { leadership }\end{array}$ & 2013 & $\begin{array}{l}\text { Journal of Knowledge } \\
\text { Management }\end{array}$ & 12 \\
\hline 211 & $\begin{array}{l}\text { McCharen B., Song } \\
\text { J.H., Martens J. }\end{array}$ & $\begin{array}{l}\text { School innovation: The mutual impacts of } \\
\text { organizational learning and creativity }\end{array}$ & 2011 & $\begin{array}{l}\text { Educational } \\
\text { Management } \\
\text { Administration and } \\
\text { Leadership }\end{array}$ & 12 \\
\hline 212 & $\begin{array}{l}\text { Kuo R.-Z., Lai M.- } \\
\text { F., Lee G.-G. }\end{array}$ & $\begin{array}{l}\text { The impact of empowering leadership for } \\
\text { KMS adoption }\end{array}$ & 2011 & Management Decision & 12 \\
\hline 213 & $\begin{array}{l}\text { González-Sánchez } \\
\text { R., García-Muiña } \\
\text { F.E. }\end{array}$ & $\begin{array}{l}\text { Open innovation: A preliminary model } \\
\text { from the knowledge-based theory } \\
\text { [Innovacioacute;n abierta: Un modelo } \\
\text { preliminar desde la gestión del } \\
\text { conocimiento] }\end{array}$ & 2011 & Intangible Capital & 12 \\
\hline 214 & $\begin{array}{l}\text { Galuppo L., Gorli } \\
\text { M., Ripamonti S. }\end{array}$ & $\begin{array}{l}\text { Playing Dissymmetry in Action Research: } \\
\text { The Role of Power and Differences in } \\
\text { Promoting Participative Knowledge and } \\
\text { Change }\end{array}$ & 2011 & $\begin{array}{l}\text { Systemic Practice and } \\
\text { Action Research }\end{array}$ & 12 \\
\hline 215 & Haughey M. & $\begin{array}{l}\text { The impact of computers on the work of } \\
\text { the principal: Changing discourses on talk, } \\
\text { leadership and professionalism }\end{array}$ & 2006 & $\begin{array}{l}\text { School Leadership and } \\
\text { Management }\end{array}$ & 12 \\
\hline 216 & Tirpak T.M. & $\begin{array}{l}\text { Five steps to effective knowledge } \\
\text { management }\end{array}$ & 2005 & $\begin{array}{l}\text { Research Technology } \\
\text { Management }\end{array}$ & 12 \\
\hline
\end{tabular}




\begin{tabular}{|c|c|c|c|c|c|}
\hline 217 & $\begin{array}{l}\text { Bavik Y.L., Tang } \\
\text { P.M., Shao R., Lam } \\
\text { L.W. }\end{array}$ & $\begin{array}{l}\text { Ethical leadership and employee } \\
\text { knowledge sharing: Exploring dual- } \\
\text { mediation paths }\end{array}$ & 2018 & Leadership Quarterly & 11 \\
\hline 218 & $\begin{array}{l}\text { Fullwood R., } \\
\text { Rowley J. }\end{array}$ & $\begin{array}{l}\text { An investigation of factors affecting } \\
\text { knowledge sharing amongst UK } \\
\text { academics }\end{array}$ & 2017 & $\begin{array}{l}\text { Journal of Knowledge } \\
\text { Management }\end{array}$ & 11 \\
\hline 219 & $\begin{array}{l}\text { Jiang W., Gu Q., } \\
\text { Wang G.G. }\end{array}$ & $\begin{array}{l}\text { To Guide or to Divide: The Dual-Side } \\
\text { Effects of Transformational Leadership on } \\
\text { Team Innovation }\end{array}$ & 2015 & $\begin{array}{l}\text { Journal of Business and } \\
\text { Psychology }\end{array}$ & 11 \\
\hline 220 & $\begin{array}{l}\text { Espedal B., } \\
\text { Gooderham P.N., } \\
\text { Stensaker I.G. }\end{array}$ & $\begin{array}{l}\text { Developing organizational social capital or } \\
\text { prima donnas in MNEs? The role of global } \\
\text { leadership development programs }\end{array}$ & 2013 & $\begin{array}{l}\text { Human Resource } \\
\text { Management }\end{array}$ & 11 \\
\hline 221 & $\begin{array}{l}\text { Mabey C., Kulich } \\
\text { C., Lorenzi-Cioldi } \\
\text { F. }\end{array}$ & $\begin{array}{l}\text { Knowledge leadership in global scientific } \\
\text { research }\end{array}$ & 2012 & $\begin{array}{l}\text { International Journal of } \\
\text { Human Resource } \\
\text { Management }\end{array}$ & 11 \\
\hline 222 & $\begin{array}{l}\text { Kristianto Y., } \\
\text { Ajmal M., } \\
\text { Tenkorang R.A., } \\
\text { Hussain M. } \\
\end{array}$ & $\begin{array}{l}\text { A study of technology adoption in } \\
\text { manufacturing firms }\end{array}$ & 2012 & $\begin{array}{l}\text { Journal of } \\
\text { Manufacturing } \\
\text { Technology } \\
\text { Management }\end{array}$ & 11 \\
\hline 223 & $\begin{array}{l}\text { Mitchell R.J., Boyle } \\
\text { B. }\end{array}$ & $\begin{array}{l}\text { A theoretical model of transformational } \\
\text { leadership's role in diverse teams }\end{array}$ & 2009 & $\begin{array}{l}\text { Leadership and } \\
\text { Organization } \\
\text { Development Journal }\end{array}$ & 11 \\
\hline 224 & Metcalfe M. & $\begin{array}{l}\text { Knowledge sharing, complex } \\
\text { environments and small-worlds }\end{array}$ & 2005 & $\begin{array}{l}\text { Human Systems } \\
\text { Management }\end{array}$ & 11 \\
\hline 225 & Le P.B., Lei H. & $\begin{array}{l}\text { How transformational leadership supports } \\
\text { knowledge sharing: Evidence from } \\
\text { Chinese manufacturing and service firms }\end{array}$ & 2017 & $\begin{array}{l}\text { Chinese Management } \\
\text { Studies }\end{array}$ & 10 \\
\hline 226 & $\begin{array}{l}\text { Cunningham J., } \\
\text { Seaman C., } \\
\text { McGuire D. }\end{array}$ & $\begin{array}{l}\text { Knowledge sharing in small family firms: } \\
\text { A leadership perspective }\end{array}$ & 2016 & $\begin{array}{l}\text { Journal of Family } \\
\text { Business Strategy }\end{array}$ & 10 \\
\hline 227 & $\begin{array}{l}\text { Cheuk B., Dervin } \\
\text { B. }\end{array}$ & $\begin{array}{l}\text { Leadership } 2.0 \text { in action: A journey from } \\
\text { knowledge management to "knowledging" }\end{array}$ & 2011 & $\begin{array}{l}\text { Knowledge } \\
\text { Management and E- } \\
\text { Learning }\end{array}$ & 10 \\
\hline 228 & Hoe S.L. & $\begin{array}{l}\text { Shared vision: A development tool for } \\
\text { organizational learning }\end{array}$ & 2007 & $\begin{array}{l}\text { Development and } \\
\text { Learning in } \\
\text { Organisations }\end{array}$ & 10 \\
\hline 229 & Jiang Y., Chen C.C. & $\begin{array}{l}\text { Integrating Knowledge Activities for } \\
\text { Team Innovation: Effects of } \\
\text { Transformational Leadership }\end{array}$ & 2018 & Journal of Management & 9 \\
\hline 230 & $\begin{array}{l}\text { Shao Z., Feng Y., } \\
\text { Hu Q. }\end{array}$ & $\begin{array}{l}\text { Impact of top management leadership } \\
\text { styles on ERP assimilation and the role of } \\
\text { organizational learning }\end{array}$ & 2017 & $\begin{array}{l}\text { Information and } \\
\text { Management }\end{array}$ & 9 \\
\hline 231 & $\begin{array}{l}\text { Nicolopoulou K., } \\
\text { Karataş-Özkan M., } \\
\text { Vas C., Nouman M. }\end{array}$ & $\begin{array}{l}\text { An incubation perspective on social } \\
\text { innovation: the London Hub - a social } \\
\text { incubator }\end{array}$ & 2017 & $R$ and $D$ Management & 9 \\
\hline 232 & $\begin{array}{l}\text { Veer Ramjeawon } \\
\text { P., Rowley J. }\end{array}$ & $\begin{array}{l}\text { Knowledge management in higher } \\
\text { education institutions: enablers and } \\
\text { barriers in Mauritius }\end{array}$ & 2017 & Learning Organization & 9 \\
\hline 233 & $\begin{array}{l}\text { Rose J., Jones M., } \\
\text { Furneaux B. }\end{array}$ & $\begin{array}{l}\text { An integrated model of innovation drivers } \\
\text { for smaller software firms }\end{array}$ & 2016 & $\begin{array}{l}\text { Information and } \\
\text { Management }\end{array}$ & 9 \\
\hline 234 & $\begin{array}{l}\text { Millar C.C.J.M., } \\
\text { Lockett M., Mahon } \\
\text { J.F. }\end{array}$ & $\begin{array}{l}\text { Guest editorial: Knowledge intensive } \\
\text { organisations: on the frontiers of } \\
\text { knowledge management }\end{array}$ & 2016 & $\begin{array}{l}\text { Journal of Knowledge } \\
\text { Management }\end{array}$ & 9 \\
\hline 235 & Schmitt U. & $\begin{array}{l}\text { Tools for exploration and exploitation } \\
\text { capability: Towards a co-evolution of } \\
\text { organizational and personal knowledge } \\
\text { management systems }\end{array}$ & 2015 & $\begin{array}{l}\text { International Journal of } \\
\text { Knowledge, Culture and } \\
\text { Change Management }\end{array}$ & 9 \\
\hline 236 & Taylor G. & $\begin{array}{l}\text { Implementing and maintaining a } \\
\text { knowledge sharing culture via knowledge } \\
\text { management teams: A shared leadership } \\
\text { approach }\end{array}$ & 2013 & $\begin{array}{l}\text { Journal of } \\
\text { Organizational Culture, } \\
\text { Communications and } \\
\text { Conflict }\end{array}$ & 9 \\
\hline
\end{tabular}




\begin{tabular}{|c|c|c|c|c|c|}
\hline 237 & $\begin{array}{l}\text { Bae S.H., Song } \\
\text { J.H., Park S., Kim } \\
\text { H.K. }\end{array}$ & $\begin{array}{l}\text { Influential factors for teachers' creativity: } \\
\text { Mutual impacts of leadership, work } \\
\text { engagement, and knowledge creation } \\
\text { practices }\end{array}$ & 2013 & $\begin{array}{l}\text { Performance } \\
\text { Improvement Quarterly }\end{array}$ & 9 \\
\hline 238 & Van Oord L. & $\begin{array}{l}\text { Towards transformative leadership in } \\
\text { education }\end{array}$ & 2013 & $\begin{array}{l}\text { International Journal of } \\
\text { Leadership in } \\
\text { Education }\end{array}$ & 9 \\
\hline 239 & $\begin{array}{l}\text { Soosay C., Hyland } \\
\text { P. }\end{array}$ & $\begin{array}{l}\text { Managing knowledge transfer as a } \\
\text { strategic approach to competitive } \\
\text { advantage }\end{array}$ & 2008 & $\begin{array}{l}\text { International Journal of } \\
\text { Technology } \\
\text { Management }\end{array}$ & 9 \\
\hline 240 & Cavaleri S., Reed F. & Leading dynamically complex projects & 2008 & $\begin{array}{l}\text { International Journal of } \\
\text { Managing Projects in } \\
\text { Business }\end{array}$ & 9 \\
\hline 241 & Yeo R.K. & $\begin{array}{l}\text { Problem-based learning: A viable } \\
\text { approach in leadership development? }\end{array}$ & 2007 & $\begin{array}{l}\text { Journal of Management } \\
\text { Development }\end{array}$ & 9 \\
\hline 242 & $\begin{array}{l}\text { Albert S.R., Fetzer } \\
\text { R.C. }\end{array}$ & $\begin{array}{l}\text { Smart community networks: Self-directed } \\
\text { team effectiveness in action }\end{array}$ & 2005 & $\begin{array}{l}\text { Team Performance } \\
\text { Management: An } \\
\text { International Journal }\end{array}$ & 9 \\
\hline 243 & Le P.B., Lei H. & $\begin{array}{l}\text { The mediating role of trust in stimulating } \\
\text { the relationship between transformational } \\
\text { leadership and knowledge sharing } \\
\text { processes }\end{array}$ & 2018 & $\begin{array}{l}\text { Journal of Knowledge } \\
\text { Management }\end{array}$ & 8 \\
\hline 244 & $\begin{array}{l}\text { Nonaka I., Hirose } \\
\text { A., Takeda Y. }\end{array}$ & $\begin{array}{l}\text { 'Meso'-Foundations of Dynamic } \\
\text { Capabilities: Team-Level Synthesis and } \\
\text { Distributed Leadership as the Source of } \\
\text { Dynamic Creativity }\end{array}$ & 2016 & Global Strategy Journal & 8 \\
\hline 245 & $\begin{array}{l}\text { Wu W.-L., Lee Y.- } \\
\text { C. }\end{array}$ & $\begin{array}{l}\text { Do employees share knowledge when } \\
\text { encountering abusive supervision? }\end{array}$ & 2016 & $\begin{array}{l}\text { Journal of Managerial } \\
\text { Psychology }\end{array}$ & 8 \\
\hline 246 & $\begin{array}{l}\text { Mabey C., Nicholds } \\
\text { A. }\end{array}$ & $\begin{array}{l}\text { Discourses of knowledge across global } \\
\text { networks: What can be learnt about } \\
\text { knowledge leadership from the ATLAS } \\
\text { collaboration? }\end{array}$ & 2015 & $\begin{array}{l}\text { International Business } \\
\text { Review }\end{array}$ & 8 \\
\hline 247 & $\begin{array}{l}\text { Alsudairi M.A.T., } \\
\text { Tatapudi G. }\end{array}$ & $\begin{array}{l}\text { Social innovation: Can it be a strategy for } \\
\text { influencing GCC public welfare? }\end{array}$ & 2014 & $\begin{array}{l}\text { Innovation: } \\
\text { Management, Policy } \\
\text { and Practice }\end{array}$ & 8 \\
\hline 248 & $\begin{array}{l}\text { Foon S.W., } \\
\text { Terziovski M. }\end{array}$ & $\begin{array}{l}\text { The impact of operations and maintenance } \\
\text { practices on power plant performance }\end{array}$ & 2014 & $\begin{array}{l}\text { Journal of } \\
\text { Manufacturing } \\
\text { Technology } \\
\text { Management } \\
\end{array}$ & 8 \\
\hline 249 & $\begin{array}{l}\text { Ranjan J., Sharma } \\
\text { V. }\end{array}$ & $\begin{array}{l}\text { A perceptual study on } \mathrm{KM} \text { orientation in } \\
\text { Indian private engineering institutions }\end{array}$ & 2012 & $\begin{array}{l}\text { International Journal of } \\
\text { Educational } \\
\text { Management }\end{array}$ & 8 \\
\hline 250 & $\begin{array}{l}\text { Tarí Guilló J.J., } \\
\text { García Fernández } \\
\text { M. }\end{array}$ & $\begin{array}{l}\text { Dimensions for knowledge managament } \\
\text { and quality management: A literature } \\
\text { review [Dimensiones de la gestión del } \\
\text { conocimiento y de la gestión de la calidad: } \\
\text { Una revisión de la literatura] }\end{array}$ & 2009 & $\begin{array}{l}\text { Investigaciones } \\
\text { Europeas de Direccion } \\
\text { y Economia de la } \\
\text { Empresa }\end{array}$ & 8 \\
\hline 251 & $\begin{array}{l}\text { Alsadhan A.O., } \\
\text { Zairi M., Keoy } \\
\text { K.H.A. }\end{array}$ & $\begin{array}{l}\text { From P economy to K economy: An } \\
\text { empirical study on knowledge-based } \\
\text { quality factors }\end{array}$ & 2008 & $\begin{array}{l}\text { Total Quality } \\
\text { Management and } \\
\text { Business Excellence } \\
\end{array}$ & 8 \\
\hline 252 & Sabri H. & $\begin{array}{l}\text { Jordanian managers' leadership styles in } \\
\text { comparison with the international air } \\
\text { transport association (IATA) and } \\
\text { prospects for knowledge management in } \\
\text { Jordan }\end{array}$ & 2007 & $\begin{array}{l}\text { International Journal of } \\
\text { Commerce and } \\
\text { Management }\end{array}$ & 8 \\
\hline 253 & Kodama M. & $\begin{array}{l}\text { Strategic community: Foundation of } \\
\text { knowledge creation }\end{array}$ & 2006 & $\begin{array}{l}\text { Research Technology } \\
\text { Management }\end{array}$ & 8 \\
\hline 254 & Kodama M. & $\begin{array}{l}\text { Innovation through dialectical leadership- } \\
\text { case studies of Japanese high-tech } \\
\text { companies }\end{array}$ & 2005 & $\begin{array}{l}\text { Journal of High } \\
\text { Technology } \\
\text { Management Research }\end{array}$ & 8 \\
\hline
\end{tabular}




\begin{tabular}{|c|c|c|c|c|c|}
\hline 255 & $\begin{array}{l}\text { Bharadwaj S.S., } \\
\text { Saxena K.B.C. }\end{array}$ & $\begin{array}{l}\text { Knowledge management in global } \\
\text { software teams }\end{array}$ & 2005 & Vikalpa & 8 \\
\hline 256 & Kodama M. & $\begin{array}{l}\text { New knowledge creation through } \\
\text { dialectical leadership: A case of IT and } \\
\text { multimedia business in Japan }\end{array}$ & 2005 & $\begin{array}{l}\text { European Journal of } \\
\text { Innovation Management }\end{array}$ & 8 \\
\hline 257 & $\begin{array}{l}\text { Calabrese R.L., } \\
\text { Roberts B. }\end{array}$ & $\begin{array}{l}\text { Character, school leadership, and the } \\
\text { brain: Learning how to integrate } \\
\text { knowledge with behavioral change }\end{array}$ & 2002 & $\begin{array}{l}\text { International Journal of } \\
\text { Educational } \\
\text { Management }\end{array}$ & 8 \\
\hline 258 & Näsi J. & $\begin{array}{l}\text { Information systems and strategy design. } \\
\text { The knowledge creation function in three } \\
\text { modes of strategy-making }\end{array}$ & 1999 & $\begin{array}{l}\text { Decision Support } \\
\text { Systems }\end{array}$ & 8 \\
\hline 259 & $\begin{array}{l}\text { Ojha D., Acharya } \\
\text { C., Cooper D. }\end{array}$ & $\begin{array}{l}\text { Transformational leadership and supply } \\
\text { chain ambidexterity: Mediating role of } \\
\text { supply chain organizational learning and } \\
\text { moderating role of uncertainty }\end{array}$ & 2018 & $\begin{array}{l}\text { International Journal of } \\
\text { Production Economics }\end{array}$ & 7 \\
\hline 260 & $\begin{array}{l}\text { De Clercq D., } \\
\text { Belausteguigoitia I. }\end{array}$ & $\begin{array}{l}\text { Mitigating the negative effect of perceived } \\
\text { organizational politics on organizational } \\
\text { citizenship behavior: Moderating roles of } \\
\text { contextual and personal resources }\end{array}$ & 2017 & $\begin{array}{l}\text { Journal of Management } \\
\text { and Organization }\end{array}$ & 7 \\
\hline 261 & $\begin{array}{l}\text { Antonacci G., } \\
\text { Fronzetti Colladon } \\
\text { A., Stefanini A., } \\
\text { Gloor P. }\end{array}$ & $\begin{array}{l}\text { It is rotating leaders who build the swarm: } \\
\text { Social network determinants of growth for } \\
\text { healthcare virtual communities of practice }\end{array}$ & 2017 & $\begin{array}{l}\text { Journal of Knowledge } \\
\text { Management }\end{array}$ & 7 \\
\hline 262 & $\begin{array}{l}\text { Sedighi M., Van } \\
\text { Splunter S., Zand } \\
\text { F., Brazier F. }\end{array}$ & $\begin{array}{l}\text { Evaluating Critical Success Factors model } \\
\text { of knowledge management: An Analytic } \\
\text { hierarchy process (AHP) approach }\end{array}$ & 2015 & $\begin{array}{l}\text { International Journal of } \\
\text { Knowledge } \\
\text { Management }\end{array}$ & 7 \\
\hline 263 & Van Den Brink M. & $\begin{array}{l}\text { The politics of knowledge: The responses } \\
\text { to feminist research from academic leaders }\end{array}$ & 2015 & $\begin{array}{l}\text { Equality, Diversity and } \\
\text { Inclusion }\end{array}$ & 7 \\
\hline 264 & $\begin{array}{l}\text { Venkitachalam K., } \\
\text { Willmott H. }\end{array}$ & $\begin{array}{l}\text { Factors shaping organizational dynamics } \\
\text { in strategic knowledge management }\end{array}$ & 2015 & $\begin{array}{l}\text { Knowledge } \\
\text { Management Research } \\
\text { and Practice }\end{array}$ & 7 \\
\hline 265 & $\begin{array}{l}\text { Ghazali R., Ahmad } \\
\text { M.N., Zakaria N.H. }\end{array}$ & $\begin{array}{l}\text { The mediating role of knowledge } \\
\text { integration in effect of leadership styles on } \\
\text { enterprise systems success: The post- } \\
\text { implementation stage }\end{array}$ & 2015 & $\begin{array}{l}\text { Journal of Enterprise } \\
\text { Information } \\
\text { Management }\end{array}$ & 7 \\
\hline 266 & $\begin{array}{l}\text { Chawla S., Lenka } \\
\text { U. }\end{array}$ & $\begin{array}{l}\text { A study on learning organizations in } \\
\text { indian higher educational institutes }\end{array}$ & 2015 & $\begin{array}{l}\text { Journal of Workplace } \\
\text { Learning }\end{array}$ & 7 \\
\hline 267 & $\begin{array}{l}\text { Sarfaraz A., Jenab } \\
\text { K., Bowker A. }\end{array}$ & $\begin{array}{l}\text { A view of development in management for } \\
\text { increasing profitability in the corporate } \\
\text { landscape }\end{array}$ & 2015 & Benchmarking & 7 \\
\hline 268 & Zumitzavan V. & $\begin{array}{l}\text { The impact of different styles of 'personal } \\
\text { knowledge management' and 'leadership' } \\
\text { on 'organisational performance': A case of } \\
\text { healthcare industry in Thailand }\end{array}$ & 2014 & $\begin{array}{l}\text { WSEAS Transactions on } \\
\text { Business and } \\
\text { Economics }\end{array}$ & 7 \\
\hline 269 & $\begin{array}{l}\text { Babnik K., Širca } \\
\text { N.T. }\end{array}$ & $\begin{array}{l}\text { Knowledge creation, transfer and } \\
\text { retention: The case of intergenerational } \\
\text { cooperation }\end{array}$ & 2014 & $\begin{array}{l}\text { International Journal of } \\
\text { Innovation and } \\
\text { Learning }\end{array}$ & 7 \\
\hline 270 & Salleh K. & $\begin{array}{l}\text { Knowledge sharing and knowledge } \\
\text { management modelling in public sector } \\
\text { accounting organisation: Case evidence } \\
\text { from Malaysia }\end{array}$ & 2013 & $\begin{array}{l}\text { International Journal of } \\
\text { Knowledge-Based } \\
\text { Development }\end{array}$ & 7 \\
\hline 271 & $\begin{array}{l}\text { Tuamsuk K., Phabu } \\
\text { T., Vongprasert C. }\end{array}$ & $\begin{array}{l}\text { Knowledge management model of } \\
\text { community business: Thai OTOP } \\
\text { Champions }\end{array}$ & 2013 & $\begin{array}{l}\text { Journal of Knowledge } \\
\text { Management }\end{array}$ & 7 \\
\hline 272 & $\begin{array}{l}\text { Griffith J.R., Fear } \\
\text { K.M., Lammers E., } \\
\text { Banaszak-Holl J., } \\
\text { Zheng K. }\end{array}$ & $\begin{array}{l}\text { A positive deviance perspective on } \\
\text { hospital knowledge management: Analysis } \\
\text { of baldrige award recipients } 2002-2008\end{array}$ & 2013 & $\begin{array}{l}\text { Journal of Healthcare } \\
\text { Management }\end{array}$ & 7 \\
\hline 273 & Sha X., Chang K.T. & $\begin{array}{l}\text { Research article the role of leadership and } \\
\text { contextualization on citizenship behaviors }\end{array}$ & 2012 & $\begin{array}{l}\text { IEEE Transactions on } \\
\text { Professional } \\
\text { Communication }\end{array}$ & 7 \\
\hline
\end{tabular}




\begin{tabular}{|c|c|c|c|c|c|}
\hline & & $\begin{array}{l}\text { in distributed teams: A relational capital } \\
\text { perspective }\end{array}$ & & & \\
\hline 274 & $\begin{array}{l}\text { Salleh K., Syed } \\
\text { Ahmad S.N., Syed- } \\
\text { Ikhsan S.O.S., Lin } \\
\text { B. }\end{array}$ & $\begin{array}{l}\text { The joint effects of organisational } \\
\text { leadership and learning factors of } \\
\text { professional intellects in sharing } \\
\text { knowledge and innovation }\end{array}$ & 2011 & $\begin{array}{l}\text { International Journal of } \\
\text { Innovation and } \\
\text { Learning }\end{array}$ & 7 \\
\hline 275 & $\begin{array}{l}\text { Doan T., Kennedy } \\
\text { M.L. }\end{array}$ & $\begin{array}{l}\text { Innovation, creativity, and meaning: } \\
\text { Leading in the information age }\end{array}$ & 2009 & $\begin{array}{l}\text { Journal of Business and } \\
\text { Finance Librarianship }\end{array}$ & 7 \\
\hline 276 & $\begin{array}{l}\text { Bravo-Ibarra E.R., } \\
\text { Herrera L. }\end{array}$ & $\begin{array}{l}\text { Innovation capability and organizational } \\
\text { resources configuration [Capacidad de } \\
\text { innovación y configuración de recursos } \\
\text { organizativos] }\end{array}$ & 2009 & Intangible Capital & 7 \\
\hline 277 & $\begin{array}{l}\text { Friedman R.S., } \\
\text { Prusak L. }\end{array}$ & $\begin{array}{l}\text { On heuristics, narrative and knowledge } \\
\text { management }\end{array}$ & 2008 & Technovation & 7 \\
\hline 278 & $\begin{array}{l}\text { Orzano A.J., } \\
\text { Ohman-Strickland } \\
\text { P.A., Patel M. }\end{array}$ & $\begin{array}{l}\text { What can family medicine practices do to } \\
\text { facilitate knowledge management? }\end{array}$ & 2008 & $\begin{array}{l}\text { Health Care } \\
\text { Management Review }\end{array}$ & 7 \\
\hline 279 & Ringer T.M. & $\begin{array}{l}\text { Leadership for collective thinking in the } \\
\text { work place }\end{array}$ & 2007 & $\begin{array}{l}\text { Team Performance } \\
\text { Management }\end{array}$ & 7 \\
\hline 280 & Johnson C. & $\begin{array}{l}\text { Leveraging Knowledge for Operational } \\
\text { Excellence }\end{array}$ & 1997 & $\begin{array}{l}\text { Journal of Knowledge } \\
\text { Management }\end{array}$ & 7 \\
\hline 281 & $\begin{array}{l}\text { Bednall T.C., E. } \\
\text { Rafferty A., } \\
\text { Shipton H., Sanders } \\
\text { K., J. Jackson C. }\end{array}$ & $\begin{array}{l}\text { Innovative Behaviour: How Much } \\
\text { Transformational Leadership Do You } \\
\text { Need? }\end{array}$ & 2018 & $\begin{array}{l}\text { British Journal of } \\
\text { Management }\end{array}$ & 6 \\
\hline 282 & $\begin{array}{l}\text { Naqshbandi M.M., } \\
\text { Tabche I. }\end{array}$ & $\begin{array}{l}\text { The interplay of leadership, absorptive } \\
\text { capacity, and organizational learning } \\
\text { culture in open innovation: Testing a } \\
\text { moderated mediation model }\end{array}$ & 2018 & $\begin{array}{l}\text { Technological } \\
\text { Forecasting and Social } \\
\text { Change }\end{array}$ & 6 \\
\hline 283 & $\begin{array}{l}\text { Cannatelli B., } \\
\text { Smith B., Giudici } \\
\text { A., Jones J., Conger } \\
\text { M. }\end{array}$ & $\begin{array}{l}\text { An Expanded Model of Distributed } \\
\text { Leadership in Organizational Knowledge } \\
\text { Creation }\end{array}$ & 2017 & Long Range Planning & 6 \\
\hline 284 & Zhang X. & $\begin{array}{l}\text { Knowledge management system use and } \\
\text { job performance: A multilevel } \\
\text { contingency model }\end{array}$ & 2017 & $\begin{array}{l}\text { MIS Quarterly: } \\
\text { Management } \\
\text { Information Systems }\end{array}$ & 6 \\
\hline 285 & $\begin{array}{l}\text { Khvatova T., Block } \\
\text { M. }\end{array}$ & $\begin{array}{l}\text { Exploring the role of task-related trust in } \\
\text { intra-organisational knowledge sharing }\end{array}$ & 2017 & $\begin{array}{l}\text { International Journal of } \\
\text { Human Resource } \\
\text { Management }\end{array}$ & 6 \\
\hline 286 & $\begin{array}{l}\text { Han S.-H., Seo G., } \\
\text { Li J., Yoon S.W. }\end{array}$ & $\begin{array}{l}\text { The mediating effect of organizational } \\
\text { commitment and employee empowerment: } \\
\text { How transformational leadership impacts } \\
\text { employee knowledge sharing intention }\end{array}$ & 2016 & $\begin{array}{l}\text { Human Resource } \\
\text { Development } \\
\text { International }\end{array}$ & 6 \\
\hline 287 & $\begin{array}{l}\text { Singer S.J., Benzer } \\
\text { J.K., Hamdan S.U. }\end{array}$ & $\begin{array}{l}\text { Improving health care quality and safety: } \\
\text { The role of collective learning }\end{array}$ & 2015 & $\begin{array}{l}\text { Journal of Healthcare } \\
\text { Leadership }\end{array}$ & 6 \\
\hline 288 & $\begin{array}{l}\text { Mojibi T., } \\
\text { Hosseinzadeh S., } \\
\text { Khojasteh Y. }\end{array}$ & $\begin{array}{l}\text { Organizational culture and its relationship } \\
\text { with knowledge management strategy: A } \\
\text { case study }\end{array}$ & 2015 & $\begin{array}{l}\text { Knowledge } \\
\text { Management Research } \\
\text { and Practice }\end{array}$ & 6 \\
\hline 289 & $\begin{array}{l}\text { Qureshi A.M.A., } \\
\text { Evans N. }\end{array}$ & $\begin{array}{l}\text { Deterrents to knowledge-sharing in the } \\
\text { pharmaceutical industry: A case study }\end{array}$ & 2015 & $\begin{array}{l}\text { Journal of Knowledge } \\
\text { Management }\end{array}$ & 6 \\
\hline 290 & $\begin{array}{l}\text { Gelard P., } \\
\text { Boroumand Z., } \\
\text { Mohammadi A. }\end{array}$ & $\begin{array}{l}\text { Relationship between transformational } \\
\text { leadership and knowledge management }\end{array}$ & 2014 & $\begin{array}{l}\text { International Journal of } \\
\text { Information Science and } \\
\text { Management }\end{array}$ & 6 \\
\hline 291 & $\begin{array}{l}\text { Rezania D., } \\
\text { Ouedraogo N. }\end{array}$ & $\begin{array}{l}\text { Organization development through ad hoc } \\
\text { problem solving: A case of knowledge } \\
\text { transfer capacity development in an ERP } \\
\text { implementation project }\end{array}$ & 2013 & $\begin{array}{l}\text { International Journal of } \\
\text { Managing Projects in } \\
\text { Business }\end{array}$ & 6 \\
\hline 292 & $\begin{array}{l}\text { Asmawi A., Zakaria } \\
\text { S., Wei C.C. }\end{array}$ & $\begin{array}{l}\text { Understanding transformational leadership } \\
\text { and R \& D culture in Malaysian } \\
\text { universities }\end{array}$ & 2013 & $\begin{array}{l}\text { Innovation: } \\
\text { Management, Policy } \\
\text { and Practice }\end{array}$ & 6 \\
\hline
\end{tabular}




\begin{tabular}{|c|c|c|c|c|c|}
\hline 293 & $\begin{array}{l}\text { Hannay L., Jaafar } \\
\text { S.B., Earl L. }\end{array}$ & $\begin{array}{l}\text { A case study of district leadership using } \\
\text { knowledge management for educational } \\
\text { change }\end{array}$ & 2013 & $\begin{array}{l}\text { Journal of } \\
\text { Organizational Change } \\
\text { Management }\end{array}$ & 6 \\
\hline 294 & $\begin{array}{l}\text { Barette J., Lemyre } \\
\text { L., Corneil W., } \\
\text { Beauregard N. }\end{array}$ & $\begin{array}{l}\text { Organizational Learning Facilitators in the } \\
\text { Canadian Public Sector }\end{array}$ & 2012 & $\begin{array}{l}\text { International Journal of } \\
\text { Public Administration }\end{array}$ & 6 \\
\hline 295 & Emstad A.B. & $\begin{array}{l}\text { The principal's role in the post-evaluation } \\
\text { process.-How does the principal engage in } \\
\text { the work carried out after the schools self- } \\
\text { evaluation? }\end{array}$ & 2011 & $\begin{array}{l}\text { Educational } \\
\text { Assessment, Evaluation } \\
\text { and Accountability }\end{array}$ & 6 \\
\hline 296 & $\begin{array}{l}\text { Hyypi\&auml; M., } \\
\text { Pekkola S. }\end{array}$ & $\begin{array}{l}\text { Interaction challenges in leadership and } \\
\text { performance management in developing a } \\
\text { network environment }\end{array}$ & 2011 & $\begin{array}{l}\text { Journal of Advances in } \\
\text { Management Research }\end{array}$ & 6 \\
\hline 297 & Nassim B. & $\begin{array}{l}\text { Investigating the impact of knowledge } \\
\text { management factors on new product } \\
\text { development performance }\end{array}$ & 2009 & $\begin{array}{l}\text { International Journal of } \\
\text { Knowledge } \\
\text { Management }\end{array}$ & 6 \\
\hline 298 & Liang T.Y. & $\begin{array}{l}\text { The new intelligence leadership strategy } \\
\text { for iCAS }\end{array}$ & 2007 & $\begin{array}{l}\text { Human Systems } \\
\text { Management }\end{array}$ & 6 \\
\hline 299 & $\begin{array}{l}\text { Nonaka I., } \\
\text { Peltokorpi V. }\end{array}$ & $\begin{array}{l}\text { Visionary knowledge management: The } \\
\text { case of Eisai transformation }\end{array}$ & 2006 & $\begin{array}{l}\text { International Journal of } \\
\text { Learning and } \\
\text { Intellectual Capital }\end{array}$ & 6 \\
\hline 300 & Pickett L. & Focus on technology misses the mark & 2004 & $\begin{array}{l}\text { Industrial and } \\
\text { Commercial Training }\end{array}$ & 6 \\
\hline 301 & $\begin{array}{l}\text { Collie S.L., Taylor } \\
\text { A.L. }\end{array}$ & $\begin{array}{l}\text { Improving teaching quality and the } \\
\text { learning organisation }\end{array}$ & 2004 & $\begin{array}{l}\text { Tertiary Education and } \\
\text { Management }\end{array}$ & 6 \\
\hline 302 & $\begin{array}{l}\text { Naqshbandi M.M., } \\
\text { Jasimuddin S.M. }\end{array}$ & $\begin{array}{l}\text { Knowledge-oriented leadership and open } \\
\text { innovation: Role of knowledge } \\
\text { management capability in France-based } \\
\text { multinationals }\end{array}$ & 2018 & $\begin{array}{l}\text { International Business } \\
\text { Review }\end{array}$ & 5 \\
\hline 303 & $\begin{array}{l}\text { Ferreras Méndez } \\
\text { J.L., Sanz Valle R., } \\
\text { Alegre J. }\end{array}$ & $\begin{array}{l}\text { Transformational leadership and } \\
\text { absorptive capacity: an analysis of the } \\
\text { organisational catalysts for this } \\
\text { relationship }\end{array}$ & 2018 & $\begin{array}{l}\text { Technology Analysis } \\
\text { and Strategic } \\
\text { Management }\end{array}$ & 5 \\
\hline 304 & $\begin{array}{l}\text { Sadeghi A., Rad } \\
\text { F.M. }\end{array}$ & $\begin{array}{l}\text { The role of knowledge-oriented leadership } \\
\text { in knowledge management and innovation }\end{array}$ & 2018 & $\begin{array}{l}\text { Management Science } \\
\text { Letters }\end{array}$ & 5 \\
\hline 305 & $\begin{array}{l}\text { Xiao Y., Zhang X., } \\
\text { Ordóñez de Pablos } \\
\text { P. }\end{array}$ & $\begin{array}{l}\text { How does individuals' exchange } \\
\text { orientation moderate the relationship } \\
\text { between transformational leadership and } \\
\text { knowledge sharing? }\end{array}$ & 2017 & $\begin{array}{l}\text { Journal of Knowledge } \\
\text { Management }\end{array}$ & 5 \\
\hline 306 & $\begin{array}{l}\text { Matić D., Cabrilo } \\
\text { S., Grubić-Nešić L., } \\
\text { Milić B. }\end{array}$ & $\begin{array}{l}\text { Investigating the impact of organizational } \\
\text { climate, motivational drivers, and } \\
\text { empowering leadership on knowledge } \\
\text { sharing }\end{array}$ & 2017 & $\begin{array}{l}\text { Knowledge } \\
\text { Management Research } \\
\text { and Practice }\end{array}$ & 5 \\
\hline 307 & $\begin{array}{l}\text { Collins N., Chou } \\
\text { Y.-M., Warner M., } \\
\text { Rowley C. }\end{array}$ & $\begin{array}{l}\text { Human factors in East Asian virtual } \\
\text { teamwork: a comparative study of } \\
\text { Indonesia, Taiwan and Vietnam }\end{array}$ & 2017 & $\begin{array}{l}\text { International Journal of } \\
\text { Human Resource } \\
\text { Management }\end{array}$ & 5 \\
\hline 308 & $\begin{array}{l}\text { Hussain S.T., } \\
\text { Abbas J., Lei S., } \\
\text { Jamal Haider M., } \\
\text { Akram T. }\end{array}$ & $\begin{array}{l}\text { Transactional leadership and } \\
\text { organizational creativity: Examining the } \\
\text { mediating role of knowledge sharing } \\
\text { behavior }\end{array}$ & 2017 & $\begin{array}{l}\text { Cogent Business and } \\
\text { Management }\end{array}$ & 5 \\
\hline 309 & Rivera M.J. & $\begin{array}{l}\text { Leveraging innovation \& intrapreneurship } \\
\text { as a source for organizational growth }\end{array}$ & 2017 & $\begin{array}{l}\text { International Journal of } \\
\text { Innovation Science }\end{array}$ & 5 \\
\hline 310 & Kwon K., Cho D. & $\begin{array}{l}\text { How transactive memory systems relate to } \\
\text { organizational innovation: the mediating } \\
\text { role of developmental leadership }\end{array}$ & 2016 & $\begin{array}{l}\text { Journal of Knowledge } \\
\text { Management }\end{array}$ & 5 \\
\hline 311 & $\begin{array}{l}\text { Sibbald S.L., } \\
\text { Wathen C.N., } \\
\text { Kothari A. }\end{array}$ & $\begin{array}{l}\text { An empirically based model for } \\
\text { knowledge management in health care } \\
\text { organizations }\end{array}$ & 2016 & $\begin{array}{l}\text { Health Care } \\
\text { Management Review }\end{array}$ & 5 \\
\hline 312 & $\begin{array}{l}\text { Gamo-Sanchez A.- } \\
\text { L., Cegarra- } \\
\text { Navarro J.-G. }\end{array}$ & $\begin{array}{l}\text { Factors that influence the success of a } \\
\text { KM-program in a small-sized airport }\end{array}$ & 2015 & $\begin{array}{l}\text { Journal of Knowledge } \\
\text { Management }\end{array}$ & 5 \\
\hline
\end{tabular}




\begin{tabular}{|c|c|c|c|c|c|}
\hline 313 & $\begin{array}{l}\text { Ali Zwain A.A., } \\
\text { Teong L.K., } \\
\text { Othman S.N. }\end{array}$ & $\begin{array}{l}\text { TQM practices and organisational } \\
\text { knowledge creation: An empirical study of } \\
\text { Iraqi Higher Education Institutions }\end{array}$ & 2014 & $\begin{array}{l}\text { Asian Journal of } \\
\text { Business and } \\
\text { Accounting }\end{array}$ & 5 \\
\hline 314 & $\begin{array}{l}\text { Cox N., Gyrd-Jones } \\
\text { R., Gardiner S. }\end{array}$ & $\begin{array}{l}\text { Internal brand management of destination } \\
\text { brands: Exploring the roles of destination } \\
\text { management organisations and operators }\end{array}$ & 2014 & $\begin{array}{l}\text { Journal of Destination } \\
\text { Marketing and } \\
\text { Management }\end{array}$ & 5 \\
\hline 315 & Seong D.N.F. & $\begin{array}{l}\text { Assessing leadership knowledge in a } \\
\text { principalship preparation programme }\end{array}$ & 2013 & $\begin{array}{l}\text { International Journal of } \\
\text { Educational } \\
\text { Management }\end{array}$ & 5 \\
\hline 316 & Miles R.E. & $\begin{array}{l}\text { Lessons learned, ignored, forgotten and } \\
\text { reborn: Organizations and management } \\
1960 \text { to today }\end{array}$ & 2011 & $\begin{array}{l}\text { Journal of Management } \\
\text { Inquiry }\end{array}$ & 5 \\
\hline 317 & $\begin{array}{l}\text { Bennet A., Bennet } \\
\text { D., Lee S.L. }\end{array}$ & $\begin{array}{l}\text { Exploring the military contribution to } \\
\text { KBD through leadership and values }\end{array}$ & 2010 & $\begin{array}{l}\text { Journal of Knowledge } \\
\text { Management }\end{array}$ & 5 \\
\hline 318 & $\begin{array}{l}\text { David R., McKenna } \\
\text { B. }\end{array}$ & $\begin{array}{l}\text { Knowledge, wisdom and intellectual } \\
\text { leadership: A question of the future and } \\
\text { knowledge-based sustainability }\end{array}$ & 2009 & $\begin{array}{l}\text { International Journal of } \\
\text { Learning and } \\
\text { Intellectual Capital }\end{array}$ & 5 \\
\hline 319 & Sakkab N.Y. & Growing through innovation & 2007 & $\begin{array}{l}\text { Research Technology } \\
\text { Management }\end{array}$ & 5 \\
\hline 320 & Kodama M. & $\begin{array}{l}\text { Innovation through networked strategic } \\
\text { communities: Case study on NTT } \\
\text { DoCoMo }\end{array}$ & 2005 & $\begin{array}{l}\text { Journal of Management } \\
\text { Development }\end{array}$ & 5 \\
\hline 321 & $\begin{array}{l}\text { Al Mansouri A.A., } \\
\text { Singh S.K., Khan } \\
\text { M. }\end{array}$ & $\begin{array}{l}\text { Role of organisational culture, leadership } \\
\text { and organisational citizenship behaviour } \\
\text { on knowledge management }\end{array}$ & 2018 & $\begin{array}{l}\text { International Journal of } \\
\text { Knowledge } \\
\text { Management Studies }\end{array}$ & 4 \\
\hline 322 & $\begin{array}{l}\text { AlShamsi O., } \\
\text { Ajmal M. }\end{array}$ & $\begin{array}{l}\text { Critical factors for knowledge sharing in } \\
\text { technology-intensive organizations: } \\
\text { evidence from UAE service sector }\end{array}$ & 2018 & $\begin{array}{l}\text { Journal of Knowledge } \\
\text { Management }\end{array}$ & 4 \\
\hline 323 & $\begin{array}{l}\text { Han S.J., Lee Y., } \\
\text { Beyerlein M., Kolb } \\
\text { J. }\end{array}$ & $\begin{array}{l}\text { Shared leadership in teams: The role of } \\
\text { coordination, goal commitment, and } \\
\text { knowledge sharing on perceived team } \\
\text { performance }\end{array}$ & 2018 & $\begin{array}{l}\text { Team Performance } \\
\text { Management }\end{array}$ & 4 \\
\hline 324 & $\begin{array}{l}\text { Smaliukienė R., } \\
\text { Bekešienè S., } \\
\text { Chlivickas E., } \\
\text { Magyla M. }\end{array}$ & $\begin{array}{l}\text { Explicating the role of trust in knowledge } \\
\text { sharing: a structural equation model test }\end{array}$ & 2017 & $\begin{array}{l}\text { Journal of Business } \\
\text { Economics and } \\
\text { Management }\end{array}$ & 4 \\
\hline 325 & $\begin{array}{l}\text { Ladan S., Nordin } \\
\text { N.B., Belal H.M. }\end{array}$ & $\begin{array}{l}\text { Does knowledge based psychological } \\
\text { ownership matter? Transformational } \\
\text { leadership and knowledge hiding: A } \\
\text { proposed framework }\end{array}$ & 2017 & $\begin{array}{l}\text { Journal of Business and } \\
\text { Retail Management } \\
\text { Research }\end{array}$ & 4 \\
\hline 326 & $\begin{array}{l}\text { Cunningham J., } \\
\text { Seaman C., } \\
\text { McGuire D. }\end{array}$ & $\begin{array}{l}\text { Perceptions of Knowledge Sharing Among } \\
\text { Small Family Firm Leaders: A Structural } \\
\text { Equation Model }\end{array}$ & 2017 & Family Business Review & 4 \\
\hline 327 & $\begin{array}{l}\text { Qasrawi B.T., } \\
\text { Almahamid S.M., } \\
\text { Qasrawi S.T. }\end{array}$ & $\begin{array}{l}\text { The impact of TQM practices and KM } \\
\text { processes on organisational performance: } \\
\text { An empirical investigation }\end{array}$ & 2017 & $\begin{array}{l}\text { International Journal of } \\
\text { Quality and Reliability } \\
\text { Management }\end{array}$ & 4 \\
\hline 328 & Tseng S.-M. & $\begin{array}{l}\text { Investigating the moderating effects of } \\
\text { organizational culture and leadership style } \\
\text { on IT-adoption and knowledge-sharing } \\
\text { intention }\end{array}$ & 2017 & $\begin{array}{l}\text { Journal of Enterprise } \\
\text { Information } \\
\text { Management }\end{array}$ & 4 \\
\hline 329 & $\begin{array}{l}\text { Valaei N., } \\
\text { Nikhashemi S.R., } \\
\text { Javan N. }\end{array}$ & $\begin{array}{l}\text { Organizational factors and process } \\
\text { capabilities in a KM strategy: toward a } \\
\text { unified theory }\end{array}$ & 2017 & $\begin{array}{l}\text { Journal of Management } \\
\text { Development }\end{array}$ & 4 \\
\hline 330 & $\begin{array}{l}\text { Liang C., Chang C.- } \\
\text { C., Rothwell W., } \\
\text { Shu K.-M. }\end{array}$ & $\begin{array}{l}\text { Influences of organizational culture on } \\
\text { knowledge sharing in an online virtual } \\
\text { community: Interactive effects of trust, } \\
\text { communication and leadership }\end{array}$ & 2016 & $\begin{array}{l}\text { Journal of } \\
\text { Organizational and End } \\
\text { User Computing }\end{array}$ & 4 \\
\hline 331 & $\begin{array}{l}\text { Argyris Y.A., } \\
\text { Ransbotham S. }\end{array}$ & $\begin{array}{l}\text { Knowledge entrepreneurship: } \\
\text { Institutionalising wiki-based knowledge- } \\
\text { management processes in competitive and } \\
\text { hierarchical organisations }\end{array}$ & 2016 & $\begin{array}{l}\text { Journal of Information } \\
\text { Technology }\end{array}$ & 4 \\
\hline
\end{tabular}




\begin{tabular}{|c|c|c|c|c|c|}
\hline 332 & $\begin{array}{l}\text { Mayfield M., } \\
\text { Mayfield J. }\end{array}$ & $\begin{array}{l}\text { Growing self-leaders: the role of } \\
\text { motivating language }\end{array}$ & 2016 & $\begin{array}{l}\text { Development and } \\
\text { Learning in } \\
\text { Organizations }\end{array}$ & 4 \\
\hline 333 & $\begin{array}{l}\text { Rahman M.S., } \\
\text { Osman-Gani A.M., } \\
\text { Momen M.A., } \\
\text { Islam N. }\end{array}$ & $\begin{array}{l}\text { Testing knowledge sharing effectiveness: } \\
\text { Trust, motivation, leadership style, } \\
\text { workplace spirituality and social network } \\
\text { embedded model }\end{array}$ & 2015 & $\begin{array}{l}\text { Management and } \\
\text { Marketing }\end{array}$ & 4 \\
\hline 334 & $\begin{array}{l}\text { Ahern T., Byrne } \\
\text { P.J., Leavy B. }\end{array}$ & $\begin{array}{l}\text { Developing complex-project capability } \\
\text { through dynamic organizational learning }\end{array}$ & 2015 & $\begin{array}{l}\text { International Journal of } \\
\text { Managing Projects in } \\
\text { Business }\end{array}$ & 4 \\
\hline 335 & $\begin{array}{l}\text { Scovetta V., Ellis } \\
\text { T.J. }\end{array}$ & $\begin{array}{l}\text { Leadership social power as a component } \\
\text { of KMS success }\end{array}$ & 2015 & $\begin{array}{l}\text { International Journal of } \\
\text { Knowledge } \\
\text { Management }\end{array}$ & 4 \\
\hline 336 & $\begin{array}{l}\text { Rodríguez-Gómez } \\
\text { D., Gairín J. }\end{array}$ & $\begin{array}{l}\text { Unravelling knowledge creation and } \\
\text { management in educational organisations: } \\
\text { Barriers and enablers }\end{array}$ & 2015 & $\begin{array}{l}\text { Knowledge } \\
\text { Management Research } \\
\text { and Practice }\end{array}$ & 4 \\
\hline 337 & $\begin{array}{l}\text { Carvaja S.A., Pérez } \\
\text { M.D., Cabello R.V., } \\
\text { Espinosa C.C. }\end{array}$ & $\begin{array}{l}\text { Identifying key factors affecting culture of } \\
\text { innovation: A case study of Chilean } \\
\text { medium mining sector [Identificación de } \\
\text { Factores Clave en la Cultura de } \\
\text { Innovación. El Caso de la Mediana } \\
\text { Minería en Chile] }\end{array}$ & 2015 & $\begin{array}{l}\text { Journal of Technology } \\
\text { Management and } \\
\text { Innovation }\end{array}$ & 4 \\
\hline 338 & $\begin{array}{l}\text { Guenzi P., Panzeri } \\
\text { F. }\end{array}$ & $\begin{array}{l}\text { How salespeople see organizational } \\
\text { citizenship behaviors: An exploratory } \\
\text { study using the laddering technique }\end{array}$ & 2015 & $\begin{array}{l}\text { Journal of Business and } \\
\text { Industrial Marketing }\end{array}$ & 4 \\
\hline 339 & $\begin{array}{l}\text { Park T.-Y., Kim J.- } \\
\text { Y. }\end{array}$ & $\begin{array}{l}\text { The capabilities required for being } \\
\text { successful in complex product systems: } \\
\text { case study of Korean e-government }\end{array}$ & 2014 & $\begin{array}{l}\text { Asian Journal of } \\
\text { Technology Innovation }\end{array}$ & 4 \\
\hline 340 & $\begin{array}{l}\text { Martín-de-Castro } \\
\text { G., Montoro- } \\
\text { Sánchez Á. }\end{array}$ & $\begin{array}{l}\text { Exploring knowledge creation and transfer } \\
\text { in the firm: Context and leadership } \\
\text { [Explorando la creación y transferencia de } \\
\text { Conocimiento en la empresa: Contexto y } \\
\text { liderazgo] }\end{array}$ & 2013 & $\begin{array}{l}\text { Universia Business } \\
\text { Review }\end{array}$ & 4 \\
\hline 341 & $\begin{array}{l}\text { Taifi N., Passiante } \\
\text { G. }\end{array}$ & $\begin{array}{l}\text { Speeding up 'New Products and Service } \\
\text { Development' through strategic } \\
\text { community creation: case of automaker } \\
\text { after-sales services partners }\end{array}$ & 2012 & $\begin{array}{l}\text { Service Industries } \\
\text { Journal }\end{array}$ & 4 \\
\hline 342 & $\begin{array}{l}\text { Jack S., Rose M., } \\
\text { Powell J. }\end{array}$ & $\begin{array}{l}\text { The university role in the innovative } \\
\text { leadership of small to medium sized } \\
\text { enterprises: Towards "universities for a } \\
\text { modern renaissance" (UMR) }\end{array}$ & 2012 & $\begin{array}{l}\text { International Journal of } \\
\text { Entrepreneurial } \\
\text { Behaviour \& Research }\end{array}$ & 4 \\
\hline 343 & $\begin{array}{l}\text { Read M., Gear T., } \\
\text { Vince R. }\end{array}$ & $\begin{array}{l}\text { Group inquiry to aid organisational } \\
\text { learning in enterprises }\end{array}$ & 2012 & $\begin{array}{l}\text { Journal of the } \\
\text { Operational Research } \\
\text { Society }\end{array}$ & 4 \\
\hline 344 & Paliszkiewicz J.O. & $\begin{array}{l}\text { The relationship between social } \\
\text { perspective and knowledge management }\end{array}$ & 2010 & $\begin{array}{l}\text { International Journal of } \\
\text { Innovation and } \\
\text { Learning }\end{array}$ & 4 \\
\hline 345 & Celep C., Çetin B. & $\begin{array}{l}\text { Teachers' perception about the behaviours } \\
\text { of school leaders with regard to } \\
\text { knowledge management }\end{array}$ & 2005 & $\begin{array}{l}\text { International Journal of } \\
\text { Educational } \\
\text { Management }\end{array}$ & 4 \\
\hline 346 & $\begin{array}{l}\text { Herremans I.M., } \\
\text { Isaac R.G. }\end{array}$ & $\begin{array}{l}\text { Leading the strategic development of } \\
\text { intellectual capital }\end{array}$ & 2004 & $\begin{array}{l}\text { Leadership \& } \\
\text { Organization } \\
\text { Development Journal }\end{array}$ & 4 \\
\hline 347 & $\begin{array}{l}\text { Sulistiyani E., } \\
\text { Udin, Rahardja E. }\end{array}$ & $\begin{array}{l}\text { Examining the effect of transformational } \\
\text { leadership, extrinsic reward, and } \\
\text { knowledge sharing on creative } \\
\text { performance of Indonesian SMEs }\end{array}$ & 2018 & $\begin{array}{l}\text { Quality - Access to } \\
\text { Success }\end{array}$ & 3 \\
\hline 348 & $\begin{array}{l}\text { Alzghoul A., } \\
\text { Elrehail H., } \\
\text { Emeagwali O.L., } \\
\text { AlShboul M.K. }\end{array}$ & $\begin{array}{l}\text { Knowledge management, workplace } \\
\text { climate, creativity and performance: The } \\
\text { role of authentic leadership }\end{array}$ & 2018 & $\begin{array}{l}\text { Journal of Workplace } \\
\text { Learning }\end{array}$ & 3 \\
\hline
\end{tabular}




\begin{tabular}{|c|c|c|c|c|c|}
\hline 349 & $\begin{array}{l}\text { Gonzalez R.V.D., } \\
\text { de Melo T.M. }\end{array}$ & $\begin{array}{l}\text { The effects of organization context on } \\
\text { knowledge exploration and exploitation }\end{array}$ & 2018 & $\begin{array}{l}\text { Journal of Business } \\
\text { Research }\end{array}$ & 3 \\
\hline 350 & $\begin{array}{l}\text { Bosch-Sijtsema } \\
\text { P.M., Tjell J. }\end{array}$ & $\begin{array}{l}\text { The concept of project space: Studying } \\
\text { construction project teams from a spatial } \\
\text { perspective }\end{array}$ & 2017 & $\begin{array}{l}\text { International Journal of } \\
\text { Project Management }\end{array}$ & 3 \\
\hline 351 & Lee K.-J. & $\begin{array}{l}\text { Knowledge sharing in franchise system: } \\
\text { franchisee self-leadership, satisfaction, } \\
\text { and compliance }\end{array}$ & 2017 & $\begin{array}{l}\text { International Journal of } \\
\text { Contemporary } \\
\text { Hospitality } \\
\text { Management }\end{array}$ & 3 \\
\hline 352 & Rai R., Prakash A. & $\begin{array}{l}\text { How do servant leaders ignite absorptive } \\
\text { capacity? the role of epistemic motivation } \\
\text { and organizational support }\end{array}$ & 2016 & $\begin{array}{l}\text { Revista de Psicologia } \\
\text { del Trabajo y de las } \\
\text { Organizaciones }\end{array}$ & 3 \\
\hline 353 & Edmondson A.C. & Wicked Problem Solvers & 2016 & $\begin{array}{l}\text { Harvard business } \\
\text { review }\end{array}$ & 3 \\
\hline 354 & $\begin{array}{l}\text { Krishnamani S., } \\
\text { Haider Y. }\end{array}$ & $\begin{array}{l}\text { Transfer of learning from executive } \\
\text { education programs in developing } \\
\text { economies: the key role of motivation }\end{array}$ & 2016 & $\begin{array}{l}\text { Development and } \\
\text { Learning in } \\
\text { Organizations }\end{array}$ & 3 \\
\hline 355 & Rivera G., Rivera I. & $\begin{array}{l}\text { Design, measurement and analysis of a } \\
\text { knowledge management model in the } \\
\text { context of a Mexican university } \\
\text { [Conception, mesurage et analyse d'un } \\
\text { modèle pour la gestion des connaissances } \\
\text { dans le contexte d'une université } \\
\text { Mexicaine] [Desenho, medição e análise } \\
\text { de um modelo para a gestão do } \\
\text { conhecimento no contexto de uma } \\
\text { universidade Mexicana] [Diseño, } \\
\text { medición y análisis de un modelo para la } \\
\text { gestión del conocimiento en el contexto de } \\
\text { una universidad Mexicana] }\end{array}$ & 2016 & Innovar & 3 \\
\hline 356 & $\begin{array}{l}\text { Mehrabani S.E., } \\
\text { Mohamad N.A. }\end{array}$ & $\begin{array}{l}\text { New approach to leadership skills } \\
\text { development (developing a model and } \\
\text { measure) }\end{array}$ & 2015 & $\begin{array}{l}\text { Journal of Management } \\
\text { Development }\end{array}$ & 3 \\
\hline 357 & $\begin{array}{l}\text { Matherly L.L., Al } \\
\text { Nahyan S.S. }\end{array}$ & $\begin{array}{l}\text { Building competitiveness through } \\
\text { effective governance of national-expatriate } \\
\text { knowledge transfer and development of } \\
\text { sustainable human capital }\end{array}$ & 2015 & $\begin{array}{l}\text { International Journal of } \\
\text { Organizational Analysis }\end{array}$ & 3 \\
\hline 358 & $\begin{array}{l}\text { Chang S.-Y., Lu } \\
\text { H.-P., Liang C.-J. }\end{array}$ & $\begin{array}{l}\text { A teaching case study: Innovation, product } \\
\text { development, and organizational } \\
\text { transformation at the Sunnic Group }\end{array}$ & 2013 & $\begin{array}{l}\text { International Journal of } \\
\text { Innovation Science }\end{array}$ & 3 \\
\hline 359 & Chan E., Mills A. & $\begin{array}{l}\text { Implementation of enterprise resource } \\
\text { planning (ERP) software in a major } \\
\text { construction contracting organization in } \\
\text { Hong Kong }\end{array}$ & 2011 & $\begin{array}{l}\text { International Journal of } \\
\text { Managing Projects in } \\
\text { Business }\end{array}$ & 3 \\
\hline 360 & Tang C. & $\begin{array}{l}\text { An empirical study on firm R\&D team's } \\
\text { creativity: Implications from China's hi- } \\
\text { tech industries }\end{array}$ & 2010 & $\begin{array}{l}\text { Journal of Science and } \\
\text { Technology Policy in } \\
\text { China }\end{array}$ & 3 \\
\hline 361 & Busari O. & $\begin{array}{l}\text { Designing the future: The knowledge } \\
\text { agenda at Trans-Caledon Tunnel Authority }\end{array}$ & 2010 & $\begin{array}{l}\text { International Journal of } \\
\text { Knowledge, Culture and } \\
\text { Change Management }\end{array}$ & 3 \\
\hline 362 & $\begin{array}{l}\text { Dos Santos I.C., } \\
\text { Neto J.A. }\end{array}$ & $\begin{array}{l}\text { Knowledge management in a high } \\
\text { technology industry }\end{array}$ & 2009 & $\begin{array}{l}\text { International Journal of } \\
\text { Innovation and } \\
\text { Technology } \\
\text { Management }\end{array}$ & 3 \\
\hline 363 & $\begin{array}{l}\text { Albinsson L., } \\
\text { Curtin G., Forsgren } \\
\text { O., Wall M. }\end{array}$ & $\begin{array}{l}\text { Creating and sustaining successful } \\
\text { knowledge management in purposeful } \\
\text { communities-summary of key experiences } \\
\text { from pioneers }\end{array}$ & 2008 & $\begin{array}{l}\text { Systems Research and } \\
\text { Behavioral Science }\end{array}$ & 3 \\
\hline 364 & $\begin{array}{l}\text { Bencsik A., Bognár } \\
\text { K. }\end{array}$ & $\begin{array}{l}\text { Success criteria of a knowledge based } \\
\text { organizational operation -or the necessity } \\
\text { of the leadership style change }\end{array}$ & 2007 & $\begin{array}{l}\text { Problems and } \\
\text { Perspectives in } \\
\text { Management }\end{array}$ & 3 \\
\hline
\end{tabular}




\begin{tabular}{|c|c|c|c|c|c|}
\hline 365 & Yeo R.K. & $\begin{array}{l}\text { Building knowledge through action } \\
\text { systems, process leadership and } \\
\text { organizational learning }\end{array}$ & 2006 & Foresight & 3 \\
\hline 366 & Kodama M. & $\begin{array}{l}\text { New knowledge creation through } \\
\text { leadership-based strategic communities: } \\
\text { Case studies in Japan }\end{array}$ & 2006 & $\begin{array}{l}\text { Systems Research and } \\
\text { Behavioral Science }\end{array}$ & 3 \\
\hline 367 & Allio R.J. & $\begin{array}{l}\text { Interview: Noel M. Tichy explains why } \\
\text { the "virtuous teaching cycle" is integral to } \\
\text { effective leadership }\end{array}$ & 2003 & Strategy \& Leadership & 3 \\
\hline 368 & Rowley J. & $\begin{array}{l}\text { The power-added manager: Strategic } \\
\text { leaders for the new millennium }\end{array}$ & 2003 & $\begin{array}{l}\text { Industrial and } \\
\text { Commercial Training }\end{array}$ & 3 \\
\hline 369 & $\begin{array}{l}\text { Dwivedi S.N., } \\
\text { Kumbakonam A. }\end{array}$ & $\begin{array}{l}\text { Effective team building process and team } \\
\text { leadership for integrated product and } \\
\text { process development }\end{array}$ & 2002 & $\begin{array}{l}\text { International Journal of } \\
\text { Human Resources } \\
\text { Development and } \\
\text { Management }\end{array}$ & 3 \\
\hline 370 & Rogers E.W. & $\begin{array}{l}\text { Enabling innovative thinking: Fostering } \\
\text { the art of knowledge crafting }\end{array}$ & 1998 & $\begin{array}{l}\text { International Journal of } \\
\text { Technology } \\
\text { Management }\end{array}$ & 3 \\
\hline 371 & $\begin{array}{l}\text { Zhou L., Zhao S., } \\
\text { Tian F., Zhang X., } \\
\text { Chen S. }\end{array}$ & $\begin{array}{l}\text { Visionary leadership and employee } \\
\text { creativity in China }\end{array}$ & 2018 & $\begin{array}{l}\text { International Journal of } \\
\text { Manpower }\end{array}$ & 2 \\
\hline 372 & Sam Liu C.-H. & $\begin{array}{l}\text { Remodelling progress in tourism and } \\
\text { hospitality students' creativity through } \\
\text { social capital and transformational } \\
\text { leadership }\end{array}$ & 2017 & $\begin{array}{l}\text { Journal of Hospitality, } \\
\text { Leisure, Sport and } \\
\text { Tourism Education }\end{array}$ & 2 \\
\hline 373 & $\begin{array}{l}\text { Anggraeni E., } \\
\text { Machfud, Maarif } \\
\text { M.S., Hartrisari }\end{array}$ & $\begin{array}{l}\text { Contextual-based knowledge creation for } \\
\text { agroindustrial innovation }\end{array}$ & 2017 & $\begin{array}{l}\text { Gadjah Mada } \\
\text { International Journal of } \\
\text { Business }\end{array}$ & 2 \\
\hline 374 & Thomas N. & $\begin{array}{l}\text { Control and autonomy irony in } \\
\text { communities of practice from a power- } \\
\text { based perspective }\end{array}$ & 2017 & $\begin{array}{l}\text { Journal of Management } \\
\text { Development }\end{array}$ & 2 \\
\hline 375 & Yu P.-L. & $\begin{array}{l}\text { Innovative culture and professional skills: } \\
\text { The use of supportive leadership and } \\
\text { individual power distance orientation in IT } \\
\text { industry }\end{array}$ & 2017 & $\begin{array}{l}\text { International Journal of } \\
\text { Manpower }\end{array}$ & 2 \\
\hline 376 & $\begin{array}{l}\text { Terouhid S.A., Ries } \\
\text { R. }\end{array}$ & $\begin{array}{l}\text { People capability: A strategic capability } \\
\text { for enhancing organizational excellence of } \\
\text { construction firms }\end{array}$ & 2016 & $\begin{array}{l}\text { Journal of Modelling in } \\
\text { Management }\end{array}$ & 2 \\
\hline 377 & $\begin{array}{l}\text { Amar A.D., Hlupic } \\
\text { V. }\end{array}$ & Leadership for knowledge organizations & 2016 & $\begin{array}{l}\text { European Journal of } \\
\text { Innovation Management }\end{array}$ & 2 \\
\hline 378 & $\begin{array}{l}\text { Parmentier G., Picq } \\
\text { T. }\end{array}$ & $\begin{array}{l}\text { Managing creative teams in small } \\
\text { ambidextrous organizations: The case of } \\
\text { videogames }\end{array}$ & 2016 & $\begin{array}{l}\text { International Journal of } \\
\text { Arts Management }\end{array}$ & 2 \\
\hline 379 & $\begin{array}{l}\text { Mahon J.F., Jones } \\
\text { N.B. }\end{array}$ & $\begin{array}{l}\text { The challenge of knowledge corruption in } \\
\text { high velocity, turbulent environments }\end{array}$ & 2016 & $\begin{array}{l}\text { VINE Journal of } \\
\text { Information and } \\
\text { Knowledge } \\
\text { Management Systems }\end{array}$ & 2 \\
\hline 380 & $\begin{array}{l}\text { Sriwidadi T., Arief } \\
\text { M., Prabowo H., } \\
\text { Muqarrabin A.M. }\end{array}$ & $\begin{array}{l}\text { Sustainable competitive advantage in } \\
\text { private higher education institutions in } \\
\text { Indonesia }\end{array}$ & 2016 & $\begin{array}{l}\text { International Journal of } \\
\text { Economics and } \\
\text { Management }\end{array}$ & 2 \\
\hline 381 & Chu K.-W. & $\begin{array}{l}\text { Leading knowledge management in a } \\
\text { secondary school }\end{array}$ & 2016 & $\begin{array}{l}\text { Journal of Knowledge } \\
\text { Management }\end{array}$ & 2 \\
\hline 382 & Kivipõld K. & $\begin{array}{l}\text { Organizational leadership capability - a } \\
\text { mechanism of knowledge coordination for } \\
\text { inducing innovative behaviour: A case } \\
\text { study in Estonian service industries }\end{array}$ & 2015 & $\begin{array}{l}\text { Baltic Journal of } \\
\text { Management }\end{array}$ & 2 \\
\hline 383 & $\begin{array}{l}\text { Basole R.C., } \\
\text { Putrevu J. }\end{array}$ & $\begin{array}{l}\text { On leadership, alliance formation, and } \\
\text { enterprise transformation }\end{array}$ & 2014 & $\begin{array}{l}\text { Journal of Enterprise } \\
\text { Transformation }\end{array}$ & 2 \\
\hline 384 & $\begin{array}{l}\text { Yiu M.Y.R., Pun } \\
\text { K.F. }\end{array}$ & $\begin{array}{l}\text { Measuring knowledge management } \\
\text { performance in industrial enterprises: An }\end{array}$ & 2014 & Learning Organization & 2 \\
\hline
\end{tabular}




\begin{tabular}{|c|c|c|c|c|c|}
\hline & & $\begin{array}{l}\text { exploratory study based on an integrated } \\
\text { model }\end{array}$ & & & \\
\hline 385 & $\begin{array}{l}\text { Magnier-Watanabe } \\
\text { R., Benton C. }\end{array}$ & $\begin{array}{l}\text { Enablers of knowledge management } \\
\text { across borders: A structural approach }\end{array}$ & 2013 & $\begin{array}{l}\text { International Journal of } \\
\text { Innovation and } \\
\text { Technology } \\
\text { Management }\end{array}$ & 2 \\
\hline 386 & $\begin{array}{l}\text { Ooi K.-B., } \\
\text { Arumugam V., Lee } \\
\text { V.-H., Wooi J.L.-S. }\end{array}$ & $\begin{array}{l}\text { Integrating TQM and HRM to achieve a } \\
\text { higher knowledge sharing in Malaysian } \\
\text { service firms: an SEM approach }\end{array}$ & 2012 & $\begin{array}{l}\text { International Journal of } \\
\text { Services, Economics } \\
\text { and Management }\end{array}$ & 2 \\
\hline 387 & $\begin{array}{l}\text { Ribeiro Jr. H.J., De } \\
\text { Cássia Magalhaes } \\
\text { Trindade Stano R. }\end{array}$ & $\begin{array}{l}\text { Astrophysics laboratory from MCT - A } \\
\text { diagnosis for the implementation of a } \\
\text { knowledge management program } \\
\text { [Laboratório nacional de astrofísica do } \\
\text { ministério da Ciência e tecnologia - Um } \\
\text { diagnóstico para implantação do programa } \\
\text { de gestão do conhecimento] }\end{array}$ & 2010 & Gestao e Producao & 2 \\
\hline 388 & Eschenbach S. & $\begin{array}{l}\text { From inspired teaching to effective } \\
\text { knowledge work and back again: A report } \\
\text { on Peter Drucker's schoolmistress and } \\
\text { what she can teach us about the } \\
\text { management and education of knowledge } \\
\text { workers }\end{array}$ & 2010 & Management Decision & 2 \\
\hline 389 & Cremer R.D. & $\begin{array}{l}\text { Chinese business schools and the future of } \\
\text { management in the post-crisis era: } \\
\text { Responsibility and opportunity }\end{array}$ & 2010 & $\begin{array}{l}\text { Chinese Management } \\
\text { Studies }\end{array}$ & 2 \\
\hline 390 & Müller-Merbach H. & $\begin{array}{l}\text { Knowledge management: A program for } \\
\text { education and leadership }\end{array}$ & 2008 & $\begin{array}{l}\text { Knowledge } \\
\text { Management Research } \\
\text { and Practice }\end{array}$ & 2 \\
\hline 391 & Burke M. & $\begin{array}{l}\text { From smart and corporate to urban and } \\
\text { edgy: Revitalising organisations in } \\
\text { turbulent environments }\end{array}$ & 2008 & $\begin{array}{l}\text { International Journal of } \\
\text { Organizational Analysis }\end{array}$ & 2 \\
\hline 392 & Ford R. & $\begin{array}{l}\text { From situated practice to informed theory: } \\
\text { Learning cycles and enabling structures }\end{array}$ & 2008 & Learning Organization & 2 \\
\hline 393 & $\begin{array}{l}\text { Chatzkel J., Saint- } \\
\text { Onge H. }\end{array}$ & $\begin{array}{l}\text { Quantum leap breakthrough performance } \\
\text { in acquisitions: The readiness and } \\
\text { generative value approach }\end{array}$ & 2007 & Management Decision & 2 \\
\hline 394 & Clark S., Scott N. & $\begin{array}{l}\text { Managing knowledge in tourism planning: } \\
\text { And how to assess your capability }\end{array}$ & 2006 & $\begin{array}{l}\text { Journal of Quality } \\
\text { Assurance in } \\
\text { Hospitality and Tourism }\end{array}$ & 2 \\
\hline 395 & $\begin{array}{l}\text { Gueldenberg S., } \\
\text { Konrath H. }\end{array}$ & $\begin{array}{l}\text { Leadership requirements in learning } \\
\text { organisations and methods to impact }\end{array}$ & 2004 & $\begin{array}{l}\text { International Journal of } \\
\text { Learning and } \\
\text { Intellectual Capital }\end{array}$ & 2 \\
\hline 396 & $\begin{array}{l}\text { Couillard D., } \\
\text { Lapierre J. }\end{array}$ & $\begin{array}{l}\text { Leadership, learning and resources for the } \\
\text { high-tech firm: An integrated view of } \\
\text { technology management }\end{array}$ & 2003 & $\begin{array}{l}\text { International Journal of } \\
\text { Technology } \\
\text { Management }\end{array}$ & 2 \\
\hline 397 & Datta P.P. & $\begin{array}{l}\text { Developing competencies to lead } \\
\text { innovation in Indian manufacturing: an } \\
\text { education model }\end{array}$ & 2018 & $\begin{array}{l}\text { International Journal of } \\
\text { Innovation Science }\end{array}$ & 1 \\
\hline 398 & $\begin{array}{l}\text { Jahmani K., Fadiya } \\
\text { S.O., Abubakar } \\
\text { A.M., Elrehail H. }\end{array}$ & $\begin{array}{l}\text { Knowledge content quality, perceived } \\
\text { usefulness, KMS use for sharing and } \\
\text { retrieval: A flock leadership application }\end{array}$ & 2018 & $\begin{array}{l}\text { VINE Journal of } \\
\text { Information and } \\
\text { Knowledge } \\
\text { Management Systems } \\
\end{array}$ & 1 \\
\hline 399 & $\begin{array}{l}\text { Gray D.E., Gabriel } \\
\text { Y. }\end{array}$ & $\begin{array}{l}\text { A community of practice or a working } \\
\text { psychological group? Group dynamics in } \\
\text { core and peripheral community } \\
\text { participation }\end{array}$ & 2018 & Management Learning & 1 \\
\hline 400 & $\begin{array}{l}\text { Chen M.-H., } \\
\text { Agrawal S. }\end{array}$ & $\begin{array}{l}\text { Exploring student's team behavior through } \\
\text { entrepreneurship education: a time-lagged } \\
\text { study }\end{array}$ & 2018 & Education and Training & 1 \\
\hline 401 & $\begin{array}{l}\text { Lee J.Y., Jang S.H., } \\
\text { Lee S.Y. }\end{array}$ & $\begin{array}{l}\text { Paternalistic leadership and knowledge } \\
\text { sharing with outsiders in emerging }\end{array}$ & 2018 & Personnel Review & 1 \\
\hline
\end{tabular}




\begin{tabular}{|c|c|c|c|c|c|}
\hline & & $\begin{array}{l}\text { economies: Based on social exchange } \\
\text { relations within the China context }\end{array}$ & & & \\
\hline 402 & $\begin{array}{l}\text { Marco-Crespo B., } \\
\text { Casapulla S., Nieto- } \\
\text { Sanchez C., Urrego } \\
\text { J.G.G., Grijalva } \\
\text { M.J. }\end{array}$ & $\begin{array}{l}\text { Youth participatory research and } \\
\text { evaluation to inform a Chagas disease } \\
\text { prevention program in Ecuador }\end{array}$ & 2018 & $\begin{array}{l}\text { Evaluation and } \\
\text { Program Planning }\end{array}$ & 1 \\
\hline 403 & Le P.B., Lei H. & $\begin{array}{l}\text { Fostering knowledge sharing behaviours } \\
\text { through ethical leadership practice: The } \\
\text { mediating roles of disclosure-based trust } \\
\text { and reliance-based trust in leadership }\end{array}$ & 2018 & $\begin{array}{l}\text { Knowledge } \\
\text { Management Research } \\
\text { and Practice }\end{array}$ & 1 \\
\hline 404 & $\begin{array}{l}\text { Kambey J.P., } \\
\text { Wuryaningrat N.F., } \\
\text { Kumajas L.I. }\end{array}$ & $\begin{array}{l}\text { Examining leadership and knowledge } \\
\text { sharing role on small and medium } \\
\text { enterprises innovation capabilities }\end{array}$ & 2018 & $\begin{array}{l}\text { International Journal of } \\
\text { Economics and } \\
\text { Business Administration }\end{array}$ & 1 \\
\hline 405 & $\begin{array}{l}\text { Najmi K., Kadir } \\
\text { A.R., Kadir M.I.A. }\end{array}$ & $\begin{array}{l}\text { Mediation effect of dynamic capability in } \\
\text { the relationship between knowledge } \\
\text { management and strategic leadership on } \\
\text { organizational performance accountability }\end{array}$ & 2018 & $\begin{array}{l}\text { International Journal of } \\
\text { Law and Management }\end{array}$ & 1 \\
\hline 406 & $\begin{array}{l}\text { Chang Y.-Y., Chao } \\
\text { W.-C., Chang C.- } \\
\text { Y., Chi H.-R. }\end{array}$ & $\begin{array}{l}\text { Transformational leadership influence on } \\
\text { unit performance: Cross-level moderated } \\
\text { mediation evidence }\end{array}$ & 2018 & $\begin{array}{l}\text { Leadership and } \\
\text { Organization } \\
\text { Development Journal }\end{array}$ & 1 \\
\hline 407 & $\begin{array}{l}\text { Gonzalez R.V.D., } \\
\text { De Melo T.M. }\end{array}$ & $\begin{array}{l}\text { Innovation by knowledge exploration and } \\
\text { exploitation: An empirical study of the } \\
\text { automotive industry }\end{array}$ & 2018 & Gestao e Producao & 1 \\
\hline 408 & $\begin{array}{l}\text { James F., Figaro- } \\
\text { Henry S. }\end{array}$ & $\begin{array}{l}\text { Building collective leadership capacity } \\
\text { using collaborative twenty-first century } \\
\text { digital tools }\end{array}$ & 2017 & $\begin{array}{l}\text { School Leadership and } \\
\text { Management }\end{array}$ & 1 \\
\hline 409 & $\begin{array}{l}\text { Supartha W.G., } \\
\text { Dewi Kumala Ratih } \\
\text { I.A. }\end{array}$ & $\begin{array}{l}\text { Antecedents of absorptive capacity: A } \\
\text { proof of proposition }\end{array}$ & 2017 & $\begin{array}{l}\text { Journal of Business and } \\
\text { Retail Management } \\
\text { Research }\end{array}$ & 1 \\
\hline 410 & Scovetta V. & $\begin{array}{l}\text { The impact of personal and positional } \\
\text { powers on knowledge management } \\
\text { systems }\end{array}$ & 2017 & $\begin{array}{l}\text { International Journal of } \\
\text { Knowledge } \\
\text { Management }\end{array}$ & 1 \\
\hline 411 & $\begin{array}{l}\text { Woodfield P.J., } \\
\text { Shepherd D., } \\
\text { Woods C. }\end{array}$ & $\begin{array}{l}\text { How can family winegrowing businesses } \\
\text { be sustained across generations? }\end{array}$ & 2017 & $\begin{array}{l}\text { International Journal of } \\
\text { Wine Business Research }\end{array}$ & 1 \\
\hline 412 & Hysmith D. & $\begin{array}{l}\text { Leading into strategic growth: building } \\
\text { capability at Global Suppliers }\end{array}$ & 2017 & $\begin{array}{l}\text { Journal of Management } \\
\text { Development }\end{array}$ & 1 \\
\hline 413 & Mahadevan K. & $\begin{array}{l}\text { Culture driven regeneration (CDR): A } \\
\text { conceptual business improvement tool }\end{array}$ & 2017 & TQM Journal & 1 \\
\hline 414 & $\begin{array}{l}\text { Boateng H., } \\
\text { Dzandu M.D., Tang } \\
\text { Y. }\end{array}$ & $\begin{array}{l}\text { Knowledge sharing among employees in } \\
\text { Ghanaian Industries: The role of } \\
\text { transformational leadership style and } \\
\text { communal organizational culture }\end{array}$ & 2016 & $\begin{array}{l}\text { Business Information } \\
\text { Review }\end{array}$ & 1 \\
\hline 415 & $\begin{array}{l}\text { Sareminia S., } \\
\text { Shamizanjani M., } \\
\text { Mousakhani M., } \\
\text { Manian A. }\end{array}$ & $\begin{array}{l}\text { Project knowledge management: An } \\
\text { ontological view }\end{array}$ & 2016 & $\begin{array}{l}\text { Knowledge } \\
\text { Management and E- } \\
\text { Learning }\end{array}$ & 1 \\
\hline 416 & $\begin{array}{l}\text { Klein J., Shapira- } \\
\text { Lishchinsky O. }\end{array}$ & $\begin{array}{l}\text { Intergenerational sharing of knowledge as } \\
\text { means of deepening the organisational } \\
\text { learning culture in schools }\end{array}$ & 2016 & $\begin{array}{l}\text { School Leadership and } \\
\text { Management }\end{array}$ & 1 \\
\hline 417 & $\begin{array}{l}\text { Aminbeidokhti A., } \\
\text { Nikabadi M.S., } \\
\text { Hoseini A.M. }\end{array}$ & $\begin{array}{l}\text { The role of transformational leadership } \\
\text { and knowledge management processes on } \\
\text { the rate of organisational innovation }\end{array}$ & 2016 & $\begin{array}{l}\text { International Journal of } \\
\text { Knowledge } \\
\text { Management Studies }\end{array}$ & 1 \\
\hline 418 & $\begin{array}{l}\text { Khajouei H., } \\
\text { Jamshidi M.J., } \\
\text { Nasrabadi H. }\end{array}$ & $\begin{array}{l}\text { Investigation and prioritisation of cultural } \\
\text { barriers against implementation of } \\
\text { knowledge management in Kerman } \\
\text { Regional Electric Company }\end{array}$ & 2016 & $\begin{array}{l}\text { International Journal of } \\
\text { Knowledge } \\
\text { Management Studies }\end{array}$ & 1 \\
\hline 419 & $\begin{array}{l}\text { Mohammadi A., } \\
\text { Boroumand Z. }\end{array}$ & $\begin{array}{l}\text { Transformational leadership and } \\
\text { knowledge sharing }\end{array}$ & 2016 & $\begin{array}{l}\text { International Journal of } \\
\text { Information Science and } \\
\text { Management }\end{array}$ & 1 \\
\hline
\end{tabular}




\begin{tabular}{|c|c|c|c|c|c|}
\hline 420 & Lin W.-B. & $\begin{array}{l}\text { Correlations of knowledge-sharing } \\
\text { intention between different enterprise } \\
\text { types and leadership styles }\end{array}$ & 2016 & $\begin{array}{l}\text { International Journal of } \\
\text { Innovation and } \\
\text { Learning }\end{array}$ & 1 \\
\hline 421 & $\begin{array}{l}\text { Nylund P.A., } \\
\text { Raelin J.D. }\end{array}$ & $\begin{array}{l}\text { When feelings obscure reason: The impact } \\
\text { of leaders' explicit and emotional } \\
\text { knowledge transfer on shareholder } \\
\text { reactions }\end{array}$ & 2015 & Leadership Quarterly & 1 \\
\hline 422 & Darby R. & $\begin{array}{l}\text { Leadership development in the asia-pacific } \\
\text { region. building capacity in the indonesia } \\
\text { defence environment a case study }\end{array}$ & 2015 & $\begin{array}{l}\text { Journal of Management } \\
\text { Development }\end{array}$ & 1 \\
\hline 423 & $\begin{array}{l}\text { Bandow D., } \\
\text { Gerweck J.T. }\end{array}$ & $\begin{array}{l}\text { Support your local communities of } \\
\text { practice: Learning and continuous change }\end{array}$ & 2015 & $\begin{array}{l}\text { Development and } \\
\text { Learning in } \\
\text { Organizations }\end{array}$ & 1 \\
\hline 424 & Berlin J.M. & $\begin{array}{l}\text { Doctors' functional leadership in } \\
\text { psychiatric healthcare teams - a reversible } \\
\text { leadership logic }\end{array}$ & 2015 & $\begin{array}{l}\text { Team Performance } \\
\text { Management }\end{array}$ & 1 \\
\hline 425 & $\begin{array}{l}\text { Mahamed Ismail } \\
\text { N.A., Welch C., Xu } \\
\text { M. }\end{array}$ & $\begin{array}{l}\text { Towards a sustainable quality of } \\
\text { university research: Knowledge sharing }\end{array}$ & 2015 & $\begin{array}{l}\text { Knowledge } \\
\text { Management Research } \\
\text { and Practice }\end{array}$ & 1 \\
\hline 426 & $\begin{array}{l}\text { Mohannak K., } \\
\text { Matthews J. }\end{array}$ & $\begin{array}{l}\text { Knowledge integration within innovation } \\
\text { process: A technopreneurial perspective }\end{array}$ & 2015 & $\begin{array}{l}\text { International Journal of } \\
\text { Technoentrepreneurship }\end{array}$ & 1 \\
\hline 427 & $\begin{array}{l}\text { Chew E., Dovey } \\
\text { K.A. }\end{array}$ & $\begin{array}{l}\text { Learning to create sustainable value in } \\
\text { turbulent operational contexts: the role of } \\
\text { leadership practices }\end{array}$ & 2014 & Learning Organization & 1 \\
\hline 428 & Gadman L.J. & $\begin{array}{l}\text { Open source leadership: Leading and } \\
\text { managing community led programmes to } \\
\text { support strategies for next generation } \\
\text { broadband implementations across Europe }\end{array}$ & 2013 & $\begin{array}{l}\text { International Journal of } \\
\text { Organizational Analysis }\end{array}$ & 1 \\
\hline 429 & Machado M. & $\begin{array}{l}\text { Educating social knowledge managers: A } \\
\text { social networking approach to } \\
\text { management education }\end{array}$ & 2013 & Management Education & 1 \\
\hline 430 & $\begin{array}{l}\text { Farkas F., Dobrai } \\
\text { K. }\end{array}$ & $\begin{array}{l}\text { Knowledge profile of Higher Education } \\
\text { Institutions: An international overview of } \\
\text { mainstream research }\end{array}$ & 2012 & $\begin{array}{l}\text { International Journal of } \\
\text { Management in } \\
\text { Education }\end{array}$ & 1 \\
\hline 431 & Chawla D., Joshi H. & $\begin{array}{l}\text { A comparative study of knowledge } \\
\text { management assessment in business } \\
\text { excellence awarded and non-awarded } \\
\text { organizations in india }\end{array}$ & 2011 & Global Business Review & 1 \\
\hline 432 & $\begin{array}{l}\text { Mathew M., Kumar } \\
\text { D., Perumal S. }\end{array}$ & $\begin{array}{l}\text { Role of knowledge management initiatives } \\
\text { in organizational innovativeness: } \\
\text { Empirical findings from the IT industry }\end{array}$ & 2011 & Vikalpa & 1 \\
\hline 433 & $\begin{array}{l}\text { Tingoy Ö., Kurt } \\
\text { Ö.E. }\end{array}$ & $\begin{array}{l}\text { Communication in knowledge } \\
\text { management practices: A survey from } \\
\text { turkey }\end{array}$ & 2009 & $\begin{array}{l}\text { Problems and } \\
\text { Perspectives in } \\
\text { Management }\end{array}$ & 1 \\
\hline 434 & Hollis R.B. & $\begin{array}{l}\text { Leader-as-teacher: A model for executive } \\
\text { development success }\end{array}$ & 2007 & $\begin{array}{l}\text { Organization } \\
\text { Development Journal }\end{array}$ & 1 \\
\hline 435 & Spath J., Judzis A. & $\begin{array}{l}\text { Promoting R\&D in management and } \\
\text { information }\end{array}$ & 2005 & $\begin{array}{l}\text { JPT, Journal of } \\
\text { Petroleum Technology }\end{array}$ & 1 \\
\hline 436 & Dayasindhu N. & $\begin{array}{l}\text { Creating an entrepreneurship milieu for } \\
\text { electronics and information technology } \\
\text { industries }\end{array}$ & 2003 & $\begin{array}{l}\text { International Journal of } \\
\text { Entrepreneurship and } \\
\text { Innovation Management }\end{array}$ & 1 \\
\hline 437 & Ramachandran I. & $\begin{array}{l}\text { Triggering absorptive capacity in } \\
\text { organizations: CEO succession as a } \\
\text { knowledge enabler }\end{array}$ & 2018 & $\begin{array}{l}\text { Journal of Knowledge } \\
\text { Management }\end{array}$ & 0 \\
\hline 438 & $\begin{array}{l}\text { Ilomäki L., Lakkala } \\
\text { M. }\end{array}$ & $\begin{array}{l}\text { Digital technology and practices for } \\
\text { school improvement: innovative digital } \\
\text { school model }\end{array}$ & 2018 & $\begin{array}{l}\text { Research and Practice } \\
\text { in Technology } \\
\text { Enhanced Learning }\end{array}$ & 0 \\
\hline 439 & $\begin{array}{l}\text { Al-Qubaisi S.S., } \\
\text { Ajmal M. }\end{array}$ & $\begin{array}{l}\text { Determinants of operational efficiency in } \\
\text { the oil and gas sector: A Balanced } \\
\text { scorecards perspective }\end{array}$ & 2018 & Benchmarking & 0 \\
\hline
\end{tabular}




\begin{tabular}{|c|c|c|c|c|c|}
\hline 440 & $\begin{array}{l}\text { Gunasekera V.S., } \\
\text { Chong S.C. }\end{array}$ & $\begin{array}{l}\text { Knowledge management critical success } \\
\text { factors and project management } \\
\text { performance outcomes in major } \\
\text { construction organisations in Sri Lanka: A } \\
\text { case study }\end{array}$ & 2018 & $\begin{array}{l}\text { VINE Journal of } \\
\text { Information and } \\
\text { Knowledge } \\
\text { Management Systems }\end{array}$ & 0 \\
\hline 441 & $\begin{array}{l}\text { Matošková J., } \\
\text { Macurová L., } \\
\text { Tomancová L. }\end{array}$ & $\begin{array}{l}\text { A link between knowledge sharing and } \\
\text { managers' characteristics }\end{array}$ & 2018 & $\begin{array}{l}\text { Leadership and } \\
\text { Organization } \\
\text { Development Journal }\end{array}$ & 0 \\
\hline 442 & $\begin{array}{l}\text { Chen Z.-J., Davison } \\
\text { R.M., Mao J.-Y., } \\
\text { Wang Z.-H. }\end{array}$ & $\begin{array}{l}\text { When and how authoritarian leadership } \\
\text { and leader renqing orientation influence } \\
\text { tacit knowledge sharing intentions }\end{array}$ & 2018 & $\begin{array}{l}\text { Information and } \\
\text { Management }\end{array}$ & 0 \\
\hline 443 & $\begin{array}{l}\text { Norbert N.S., Jr., } \\
\text { Bischoff J.E., Willy } \\
\text { C.J. }\end{array}$ & $\begin{array}{l}\text { Barriers impeding knowledge } \\
\text { management for hardware integration and } \\
\text { engineering teams }\end{array}$ & 2018 & $\begin{array}{l}\text { Knowledge } \\
\text { Management Research } \\
\text { and Practice }\end{array}$ & 0 \\
\hline 444 & $\begin{array}{l}\text { Srivastava A.P., } \\
\text { Joshi Y. }\end{array}$ & $\begin{array}{l}\text { Examining the role of technology } \\
\text { leadership on knowledge sharing } \\
\text { behaviour }\end{array}$ & 2018 & $\begin{array}{l}\text { International Journal of } \\
\text { Knowledge } \\
\text { Management }\end{array}$ & 0 \\
\hline 445 & $\begin{array}{l}\text { Juan S.H., Ting } \\
\text { I.W.K., Kweh Q.L., } \\
\text { Yao L. }\end{array}$ & $\begin{array}{l}\text { How does knowledge sharing affect } \\
\text { employee engagement? }\end{array}$ & 2018 & $\begin{array}{l}\text { Institutions and } \\
\text { Economies }\end{array}$ & 0 \\
\hline 446 & $\begin{array}{l}\text { Al Dari T., Jabeen } \\
\text { F., } \\
\text { Papastathopoulos } \\
\text { A. }\end{array}$ & $\begin{array}{l}\text { Examining the role of leadership } \\
\text { inspiration, rewards and its relationship } \\
\text { with contribution to knowledge sharing: } \\
\text { Evidence from the UAE }\end{array}$ & 2018 & $\begin{array}{l}\text { Journal of Workplace } \\
\text { Learning }\end{array}$ & 0 \\
\hline 447 & Park S., Kim E.-J. & $\begin{array}{l}\text { Fostering organizational learning through } \\
\text { leadership and knowledge sharing }\end{array}$ & 2018 & $\begin{array}{l}\text { Journal of Knowledge } \\
\text { Management }\end{array}$ & 0 \\
\hline 448 & $\begin{array}{l}\text { Al-husseini S., } \\
\text { Elbeltagi I. }\end{array}$ & $\begin{array}{l}\text { Evaluating the effect of transformational } \\
\text { leadership on knowledge sharing using } \\
\text { structural equation modelling: the case of } \\
\text { Iraqi higher education }\end{array}$ & 2018 & $\begin{array}{l}\text { International Journal of } \\
\text { Leadership in } \\
\text { Education }\end{array}$ & 0 \\
\hline 449 & $\begin{array}{l}\text { Rosli A., de Silva } \\
\text { M., Rossi F., Yip } \\
\text { N. }\end{array}$ & $\begin{array}{l}\text { The long-term impact of engaged } \\
\text { scholarship: How do SMEs capitalise on } \\
\text { their engagement with academics to } \\
\text { explore new opportunities? }\end{array}$ & 2018 & $\begin{array}{l}\text { International Small } \\
\text { Business Journal: } \\
\text { Researching } \\
\text { Entrepreneurship }\end{array}$ & 0 \\
\hline 450 & $\begin{array}{l}\text { Lauzier M., } \\
\text { Barrette J., Kenny } \\
\text { S., Lemyre L. }\end{array}$ & $\begin{array}{l}\text { Validation of a short form of the Inventory } \\
\text { of Organizational Learning Facilitators: A } \\
\text { national survey of public service } \\
\text { executives in Canada }\end{array}$ & 2018 & $\begin{array}{l}\text { Journal of Workplace } \\
\text { Learning }\end{array}$ & 0 \\
\hline 451 & $\begin{array}{l}\text { Souteh R.G., } \\
\text { Esmaeili M.R., } \\
\text { Honari H., } \\
\text { Ghorbani M.H. }\end{array}$ & $\begin{array}{l}\text { The factors affecting knowledge sharing at } \\
\text { the Iranian Ministry of Sports }\end{array}$ & 2018 & $\begin{array}{l}\text { Annals of Applied Sport } \\
\text { Science }\end{array}$ & 0 \\
\hline 452 & O'brien J. & $\begin{array}{l}\text { The need for competing commitments } \\
\text { research: Coping with change in } \\
\text { knowledge management }\end{array}$ & 2018 & Change Management & 0 \\
\hline 453 & $\begin{array}{l}\text { Ghomi H., } \\
\text { Barzinpour F. }\end{array}$ & $\begin{array}{l}\text { Identifying the success factors of } \\
\text { knowledge management tools in research } \\
\text { projects (Case study: A corporate } \\
\text { university) }\end{array}$ & 2018 & $\begin{array}{l}\text { Management Science } \\
\text { Letters }\end{array}$ & 0 \\
\hline 454 & $\begin{array}{l}\text { Othman A., Ismail } \\
\text { S., Yahya K., } \\
\text { Ahmad M.H. }\end{array}$ & $\begin{array}{l}\text { Critical success factors in implementing } \\
\text { knowledge management in consultant } \\
\text { firms for Malaysian construction industry }\end{array}$ & 2018 & $\begin{array}{l}\text { Management Science } \\
\text { Letters }\end{array}$ & 0 \\
\hline 455 & $\begin{array}{l}\text { Fu L., Liu Z., Liao } \\
\text { S. }\end{array}$ & $\begin{array}{l}\text { Is distributed leadership a driving factor of } \\
\text { innovation ambidexterity? An empirical } \\
\text { study with mediating and moderating } \\
\text { effects }\end{array}$ & 2018 & $\begin{array}{l}\text { Leadership and } \\
\text { Organization } \\
\text { Development Journal }\end{array}$ & 0 \\
\hline 456 & Solomon E. & $\begin{array}{l}\text { Organizational learning, integrity and } \\
\text { value through process-oriented } \\
\text { innovations }\end{array}$ & 2018 & $\begin{array}{l}\text { Human Systems } \\
\text { Management }\end{array}$ & 0 \\
\hline 457 & $\begin{array}{l}\text { Lin K.-J., Hsieh Y.- } \\
\text { H., Lian W.-S. }\end{array}$ & $\begin{array}{l}\text { Knowledge sharing and personality traits } \\
\text { moderated by transformational leadership }\end{array}$ & 2018 & $\begin{array}{l}\text { Human Systems } \\
\text { Management }\end{array}$ & 0 \\
\hline
\end{tabular}




\begin{tabular}{|c|c|c|c|c|c|}
\hline 458 & $\begin{array}{l}\text { Agyemang F.G., } \\
\text { Boateng H., } \\
\text { Dzandu M.D. }\end{array}$ & $\begin{array}{l}\text { Examining intellectual stimulation, } \\
\text { idealised influence and individualised } \\
\text { consideration as an antecedent to } \\
\text { knowledge sharing: Evidence from Ghana }\end{array}$ & 2017 & $\begin{array}{l}\text { Knowledge } \\
\text { Management and E- } \\
\text { Learning }\end{array}$ & 0 \\
\hline 459 & $\begin{array}{l}\text { Ladan S., Nordin } \\
\text { N.B., Belal H.M. }\end{array}$ & $\begin{array}{l}\text { Influence of transformational leadership } \\
\text { on knowledge hiding: Mediating role of } \\
\text { organizational psychological ownership }\end{array}$ & 2017 & $\begin{array}{l}\text { International Journal of } \\
\text { Business and } \\
\text { Management Science }\end{array}$ & 0 \\
\hline 460 & $\begin{array}{l}\text { Rahman S., Islam } \\
\text { M.Z., Abdullah } \\
\text { A.D.A. }\end{array}$ & $\begin{array}{l}\text { Understanding factors affecting } \\
\text { knowledge sharing: A proposed } \\
\text { framework for Bangladesh's business } \\
\text { organizations }\end{array}$ & 2017 & $\begin{array}{l}\text { Journal of Science and } \\
\text { Technology Policy } \\
\text { Management }\end{array}$ & 0 \\
\hline 461 & $\begin{array}{l}\text { Jackson B.N., } \\
\text { Purdy S.C., } \\
\text { Cooper-Thomas H. }\end{array}$ & $\begin{array}{l}\text { Professional expertise amongst speech- } \\
\text { language therapists: "willing to share" }\end{array}$ & 2017 & $\begin{array}{l}\text { Journal of Health, } \\
\text { Organisation and } \\
\text { Management }\end{array}$ & 0 \\
\hline 462 & Borzillo S. & $\begin{array}{l}\text { Balancing control and autonomy in } \\
\text { communities of practice: governance } \\
\text { patterns and knowledge in nine } \\
\text { multinationals }\end{array}$ & 2017 & $\begin{array}{l}\text { Journal of Business } \\
\text { Strategy }\end{array}$ & 0 \\
\hline 463 & Wahda & $\begin{array}{l}\text { Mediating effect of knowledge } \\
\text { management on LEADERSHIP } \\
\text { TOWARD organization performance of } \\
\text { State Organization for Higher Education } \\
\text { (PTN) in South Sulawesi }\end{array}$ & 2017 & $\begin{array}{l}\text { International Journal of } \\
\text { Economic Research }\end{array}$ & 0 \\
\hline 464 & $\begin{array}{l}\text { Besen F., Tecchio } \\
\text { E., Fialho F.A.P. }\end{array}$ & $\begin{array}{l}\text { Authentic leadership and knowledge } \\
\text { management }\end{array}$ & 2017 & Gestao e Producao & 0 \\
\hline 465 & Nandedkar A. & $\begin{array}{l}\text { Investigating leader-member exchange } \\
\text { and employee envy: An evidence from the } \\
\text { information technology industry }\end{array}$ & 2016 & $\begin{array}{l}\text { International Journal of } \\
\text { Organization Theory } \\
\text { and Behavior }\end{array}$ & 0 \\
\hline 466 & $\begin{array}{l}\text { Joshi H., Farooquie } \\
\text { J.A., Chawla D. }\end{array}$ & $\begin{array}{l}\text { Knowledge Management Practices in } \\
\text { Indian Organizations-A Sectoral } \\
\text { Comparison }\end{array}$ & 2016 & Vision & 0 \\
\hline 467 & $\begin{array}{l}\text { Dastmalchian A., } \\
\text { Rezac D., Muzyka } \\
\text { D.F., Bayraktar S., } \\
\text { Steinke C., Imer } \\
\text { H.P. }\end{array}$ & $\begin{array}{l}\text { Developing a measure for "connectorship" } \\
\text { as a component of engaged leadership }\end{array}$ & 2016 & $\begin{array}{l}\text { Leadership and } \\
\text { Organization } \\
\text { Development Journal }\end{array}$ & 0 \\
\hline 468 & $\begin{array}{l}\text { Malarvizhi C.A., } \\
\text { Tiang M.C., Al- } \\
\text { Mamun A., Raston } \\
\text { N.A. }\end{array}$ & $\begin{array}{l}\text { Determining the effect of organisational } \\
\text { culture on knowledge management for } \\
\text { SMEs in Malaysia }\end{array}$ & 2016 & $\begin{array}{l}\text { International Journal of } \\
\text { Business Innovation and } \\
\text { Research }\end{array}$ & 0 \\
\hline 469 & $\begin{array}{l}\text { Sarkar R.K., } \\
\text { Mostaghimi M.R., } \\
\text { Akbari M. }\end{array}$ & $\begin{array}{l}\text { Investigate the role of knowledge-oriented } \\
\text { leadership in innovation and knowledge } \\
\text { management practices }\end{array}$ & 2016 & $\begin{array}{l}\text { International Business } \\
\text { Management }\end{array}$ & 0 \\
\hline 470 & $\begin{array}{l}\text { Almudallal A.W., } \\
\text { Bakri N., Muktar } \\
\text { S.N., El-Farra } \\
\text { M.M. }\end{array}$ & $\begin{array}{l}\text { Implementing knowledge management in } \\
\text { the Palestinian public sector institutions: } \\
\text { Empirical study on the presidency of the } \\
\text { Palestinian government }\end{array}$ & 2016 & $\begin{array}{l}\text { International Review of } \\
\text { Management and } \\
\text { Marketing }\end{array}$ & 0 \\
\hline 471 & $\begin{array}{l}\text { Burk E., Pegues J., } \\
\text { Taylor C. }\end{array}$ & $\begin{array}{l}\text { Pivotal organizational success factors in a } \\
\text { cyberspace classroom }\end{array}$ & 2015 & $\begin{array}{l}\text { Knowledge } \\
\text { Management }\end{array}$ & 0 \\
\hline 472 & Rao M.S. & $\begin{array}{l}\text { Myths and truths about coaching: How to } \\
\text { acquire right perspective to enhance } \\
\text { leadership excellence }\end{array}$ & 2015 & $\begin{array}{l}\text { Human Resource } \\
\text { Management } \\
\text { International Digest }\end{array}$ & 0 \\
\hline 473 & $\begin{array}{l}\text { Darus A.Hj., } \\
\text { Ramalu S.A.L.S., } \\
\text { Noor N.A.M., } \\
\text { Abidin Z.Z. }\end{array}$ & $\begin{array}{l}\text { Transformational leadership style and } \\
\text { knowledge management among university } \\
\text { administrators in Malaysia: Examining the } \\
\text { moderating effect of organizational } \\
\text { structure }\end{array}$ & 2014 & $\begin{array}{l}\text { International Journal of } \\
\text { Economic Research }\end{array}$ & 0 \\
\hline 474 & $\begin{array}{l}\text { Luo J., Xu F., Li } \\
\text { D., Zhong J. }\end{array}$ & $\begin{array}{l}\text { A case study on executive leadership and } \\
\text { knowledge transfer in TMT: From the } \\
\text { perspective of managerial rotation in } \\
\text { private firms }\end{array}$ & 2014 & $\begin{array}{l}\text { Frontiers of Business } \\
\text { Research in China }\end{array}$ & 0 \\
\hline
\end{tabular}




\begin{tabular}{|c|c|c|c|c|c|}
\hline 475 & $\begin{array}{l}\text { Chong C.W., Gan } \\
\text { G.C. }\end{array}$ & $\begin{array}{l}\text { Are KM strategies effectively } \\
\text { implemented in Malaysian MSC status } \\
\text { corporations? }\end{array}$ & 2013 & $\begin{array}{l}\text { International Journal of } \\
\text { Innovation and } \\
\text { Learning }\end{array}$ & 0 \\
\hline 476 & $\begin{array}{l}\text { Thang N.N., Quang } \\
\text { T., Son N.H. }\end{array}$ & $\begin{array}{l}\text { Knowledge creation and green } \\
\text { entrepreneurship: A study of two } \\
\text { Vietnamese green firms }\end{array}$ & 2013 & $\begin{array}{l}\text { Asian Academy of } \\
\text { Management Journal }\end{array}$ & 0 \\
\hline 477 & Sofo F. & $\begin{array}{l}\text { Designer leadership: Research } \\
\text { perspectives on learning transfer for } \\
\text { generative educational leadership }\end{array}$ & 2013 & $\begin{array}{l}\text { International Journal of } \\
\text { Educational } \\
\text { Organization and } \\
\text { Leadership }\end{array}$ & 0 \\
\hline 478 & Long K.E. & $\begin{array}{l}\text { Implementing appreciative sharing of } \\
\text { knowledge in the us army command and } \\
\text { general staff college }\end{array}$ & 2012 & $\begin{array}{l}\text { International Journal of } \\
\text { Commerce and } \\
\text { Management }\end{array}$ & 0 \\
\hline 479 & $\begin{array}{l}\text { Kareem O.A., Bing } \\
\text { K.W., Jusoff K., } \\
\text { Awang M., Yunus } \\
\text { J.N. }\end{array}$ & $\begin{array}{l}\text { Teacher capacity building in teaching and } \\
\text { learning: The changing role of school } \\
\text { leadership }\end{array}$ & 2011 & Academic Leadership & 0 \\
\hline 480 & Watts S., Curley K. & $\begin{array}{l}\text { Controlling adaptation at the edges: Dual- } \\
\text { process organizational learning }\end{array}$ & 2011 & $\begin{array}{l}\text { Problems and } \\
\text { Perspectives in } \\
\text { Management }\end{array}$ & 0 \\
\hline 481 & Khan M. & $\begin{array}{l}\text { The effective use of photoessays in the } \\
\text { teaching of leadership courses }\end{array}$ & 2011 & $\begin{array}{l}\text { International Journal of } \\
\text { Knowledge, Culture and } \\
\text { Change Management }\end{array}$ & 0 \\
\hline 482 & $\begin{array}{l}\text { Arroyo A.C., } \\
\text { Walker D.H.T. }\end{array}$ & $\begin{array}{l}\text { The role of the Atlantic corridor project as } \\
\text { a form of strategic community of practice } \\
\text { in facilitating business transformations in } \\
\text { Latin America }\end{array}$ & 2010 & $\begin{array}{l}\text { International Journal of } \\
\text { Managing Projects in } \\
\text { Business }\end{array}$ & 0 \\
\hline 483 & $\begin{array}{l}\text { Farias V., Oliveira } \\
\text { J., Souza J. }\end{array}$ & $\begin{array}{l}\text { Knowledge management integrating } \\
\text { organizational learning in a military } \\
\text { context: The } 3 \mathrm{M} \text { model }\end{array}$ & 2009 & $\begin{array}{l}\text { International Journal of } \\
\text { Knowledge, Culture and } \\
\text { Change Management }\end{array}$ & 0 \\
\hline 484 & $\begin{array}{l}\text { Chaharbaghi K., } \\
\text { Newman V. }\end{array}$ & $\begin{array}{l}\text { Cruel Comforters: Management Gurus as } \\
\text { Outsourced Thinkers }\end{array}$ & 2007 & $\begin{array}{l}\text { Philosophy of } \\
\text { Management }\end{array}$ & 0 \\
\hline 485 & Green J., Aitken P. & $\begin{array}{l}\text { Creating a leadership culture for } \\
\text { knowledge utilisation }\end{array}$ & 2006 & $\begin{array}{l}\text { Journal of Medical } \\
\text { Marketing: Device, } \\
\text { Diagnostic and } \\
\text { Pharmaceutical } \\
\text { Marketing }\end{array}$ & 0 \\
\hline 486 & Lloyd B., Mori M. & Leadership: An "alternative" view & 2002 & $\begin{array}{l}\text { Leadership \& } \\
\text { Organization } \\
\text { Development Journal }\end{array}$ & 0 \\
\hline 487 & Lloyd B., Ticoll D. & Digital capital and leadership & 2001 & $\begin{array}{l}\text { Leadership \& } \\
\text { Organization } \\
\text { Development Journal }\end{array}$ & 0 \\
\hline 488 & McLagan P.A. & $\begin{array}{l}\text { Invited reaction: Intellectualizing should } \\
\text { not relieve the need to act }\end{array}$ & 1993 & $\begin{array}{l}\text { Human Resource } \\
\text { Development Quarterly }\end{array}$ & 0 \\
\hline
\end{tabular}

\section{Deposit licences}

Emerald allows authors to deposit their AAM under the Creative Commons Attribution Noncommercial International Licence 4.0 (CC BY-NC 4.0). To do this, the deposit must clearly state that the AAM is deposited under this licence and that any reuse is allowed in accordance with the terms outlined by the licence. To reuse the AAM for commercial purposes, permission should be sought by contacting permissions@emeraldinsight.com.

For the sake of clarity, commercial usage would be considered as, but not limited to:

o Copying or downloading AAMs for further distribution for a fee;

o Any use of the AAM in conjunction with advertising;

o Any use of the AAM by for promotional purposes by for-profit organisations;

o Any use that would confer monetary reward, commercial gain or commercial exploitation. 
Emerald appreciates that some authors may not wish to use the CC BY-NC licence; in this case, you should deposit the AAM and include the copyright line of the published article. Should you have any questions about our licensing policies, please contact permissions@emeraldinsight.com. 